200)

$R_{i}^{\prime}$

$10.85-4056$

\title{
GEOHYDROLOGY \\ AND \\ GROUND-WATER FLOW \\ AT \\ VERONA WELL FIELD, \\ BATTLE CREEK, \\ MICHIGAN
}

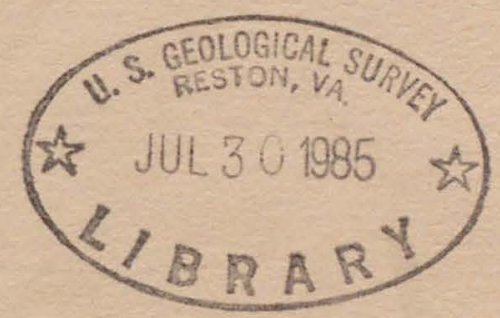

\section{U.S. GEOLOGICAL SURVEY}

Water-Resources Investigations Report 85-4056

Prepared in cooperation with the

CITY OF BATTLE CREEK, MICHIGAN
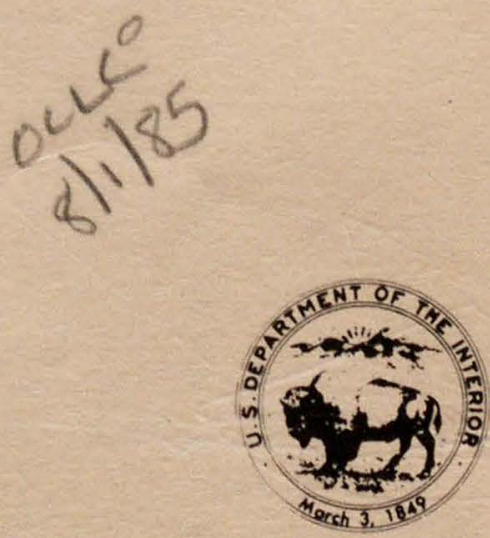
GEOHYDROLOGY AND

GROUND-WATER FLOW AT VERONA WELL

FIELD, BATTLE CREEK, MICHIGAN

By N. G. Grannemann and F. R. Twenter

U.S. GEOLOGICAL SURVEY

Water-Resources Investigations Report 85-4056

Prepared in cooperation with the

CITY OF BATTLE CREEK, MICHIGAN

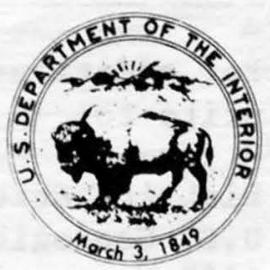

Lansing, Michigan

1985 
UNITED STATES DEPARTMENT OF THE INTERIOR

WILLIAM P. CLARK, Secretary

GEOLOGICAL SURVEY

Dallas L. Peck, Director

For additional information write to:

District Chief

U.S. Geological Survey 6520 Mercantile Way, Suite 5 Lansing, Michigan 48910
Copies of this report can be purchased from:

Open-File Services Section Western Distribution Branch U.S. Geological Survey Box 25425, Federal Center Denver, Colorado 80225

Telephone: (303) 236-7476 


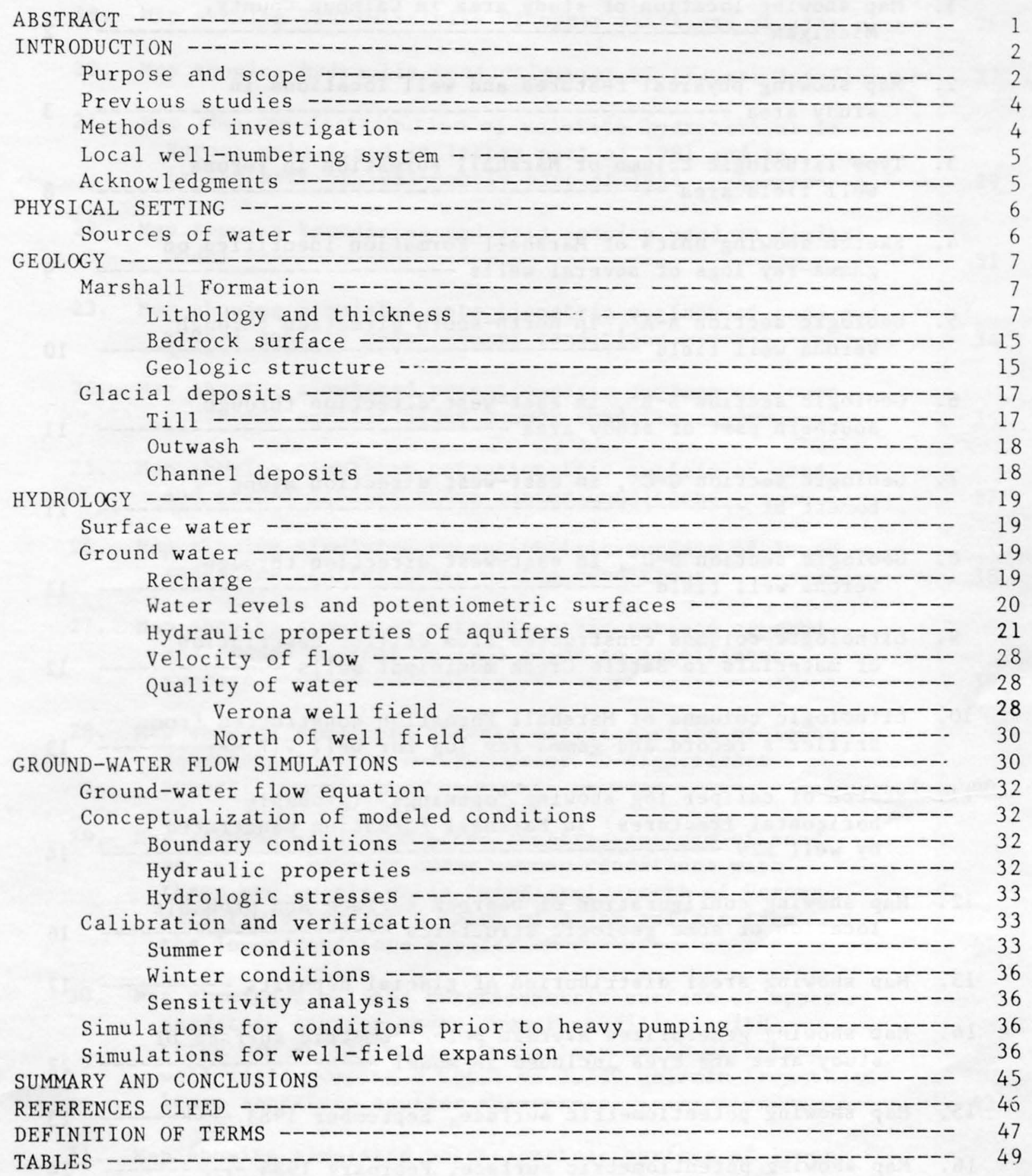




\section{FIGURES}

Page

1. Map showing location of study area in Calhoun County, Michigan

2. Map showing physical features and well locations in study area

3. Type lithologic column of Marshall Formation in Verona well field area

4. Sketch showing units of Marshall Formation identified on gamma-ray logs of several wells

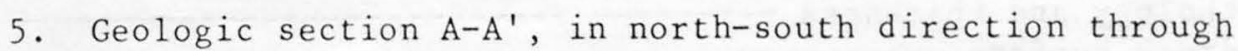
Verona well field

6. Geologic section B-B', in east-west direction through southern part of study area

7. Geologic section $\mathrm{C}^{-C^{\prime}}$, in east-west direction along Emmett $\mathrm{St}$

8. Geologic section D-D', in east-west direction through Verona well field

9. Lithologic columns constructed from driller description of materials in Battle Creek municipal wells

10. Lithologic columns of Marshall Formation constructed from driller's record and gamma-ray $\log$ for well V17 _.......--

11. Sketch of caliper log showing "openings" (probable horizontal fractures) in Marshall Formation penetrated by well E29

12. Map showing configuration of bedrock surface and probable location of some geologic structures

13. Map showing areal distribution of glacial deposits - - - - -

14. Map showing generalized average potentiometric surface of study area and area included in model

15. Map showing potentiometric surface, September 1983

16. Map showing potentiometric surface, February 1984

17. Graph showing drawdown in well E34 during pumping test at well E36 and Theis type curve _...

18. Map showing transmissivity of lower sandstone aquifer 
19. Map showing transmissivity of upper sandstone aquifer _..._- 26

20. Map showing hydraulic conductivities of glacial deposits --- 27

21. Map showing distribution of volatile hydrocarbons in Verona well field in latter part of 1981 and in latter part of 1983--early part of 1984

22. Map showing boundaries and grid spacing used in digital model

23. Map showing simulated potentiometric surface of sand and gravel aquifer under summer conditions

24. Map showing simulated potentiometric surface of lower sandstone aquifer under summer conditions

25. Map showing simulated potentiometric surface of sand and gravel aquifer under winter conditions

26. Map showing simulated potentiometric surface of lower sandstone aquifer under winter conditions

27. Map showing simulated potentiometric surface of sand and gravel aquifer in 1903 prior to significant pumpage

28. Map showing simulated potentiometric surface of lower sandstone aquifer in 1903 prior to significant pumpage

29. Map showing simulated potentiometric surface of sand and gravel aquifer under summer conditions with three new supply wells immediately north of Verona well field pumping a total of $3,750 \mathrm{gal} / \mathrm{min}$ from the lower sandstone aquifer

30. Map showing simulated potentiometric surface of upper sandstone aquifer under summer conditions with three new supply wells immediately north of Verona well field pumping a total of $3,750 \mathrm{gal} / \mathrm{min}$ from the lower sandstone aquifer

31. Map showing simulated potentiometric surface of lower sandstone aquifer under summer conditions with three new supply wells immediately north of Verona well field pumping a total of $3,750 \mathrm{gal} / \mathrm{min}$ from the lower sandstone aquifer 


\section{TABLES}

Page

1. Selected data for wells installed by U.S. Geological

Survey $\ldots$

2. Selected data for city of Battle Creek's wells .............. 6

3. Description of rocks and soils from wells drilled by

U.S. Geological Survey ........................... 50

4. Water levels in observation wells

5. Volatile hydrocarbons in verona well field .................... 28

6. Chemical and physical characteristics of water from observation wells north of Verona well field ......... 30

7. Pumping conditions that provide a sufficient supply of water to meet average summer demand 


\section{GEOHYDROLOGY AND GROUND-WATER FLOW AT VERONA WELL FIELD, BATTLE CREEK, MICHIGAN}

RY

N. G. Grannemann and F. R. Twenter

\section{ABSTRACT}

The city of Battle Creek has 30 wells in the Verona well field capable of yielding 300 to 1,000 gallons per minute each for municipal supply. In early 1984, however, only 9 to 12 of the wells were being used. Water in and near the other wells was contaminated by volatile hydrocarbons.

Ground water at and near Verona well field generally flows toward Battle Creek River except where directions are altered by pumping. During summer, especially during periods when withdrawals are as much as 12,000 gallons per minute, a large cone of depression develops and water is drawn to the well field from several thousand feet away. During winter, when withdrawals are as little as 6,000 gallons per minute, the cone is smaller.

Ground-water flow is in three aquifers--a sand and gravel aquifer of Pleistocene age and upper and lower sandstone aquifers of the Marshall Formation of Mississippian age. Model-simulated data that best matched measured data indicate horizontal hydraulic conductivities ranging from 15 to 110 feet per day for the sand and gravel aquifer, 150 feet per day for the upper sandstone aquifer, and 550 feet per day for the lower sandstone aquifer. Recharge was simulated at rates ranging from 8 to 13 inches per year.

Model simulations to evaluate the feasibility of installing new supply wells immediately north of the present field indicate that pumping 3,750 gallons per minute from new wells at the site would produce about 7 feet of drawdown in the lower sandstone aquifer in the vicinity of the new wells. Because the new wells tap only the lower sandstone aquifer, the pumping would have little effect on the potentiometric surfaces for the two overlying aquifers. 
The city of Battle Creek in Calhoun County, Michigan (fig. 1), obtains its municipal water supply from wells in the Verona well field. The field, established in 1903 in the valley of Battle Creek River, has 30 operational wells on the east and west sides of the river (fig. 2).

In 1981, volatile organic hydrocarbons were found in water from eight municipal wells. In an effort to protect the well field by purging contaminants before they reached producing wells, two wells were pumped to waste at a combined rate of $2,000 \mathrm{gal} / \mathrm{min}$. This effort was discontinued in September 1982 as evidence accumulated that the pumping, rather than producing the desired result, might be accelerating the movement of contaminants to the field.

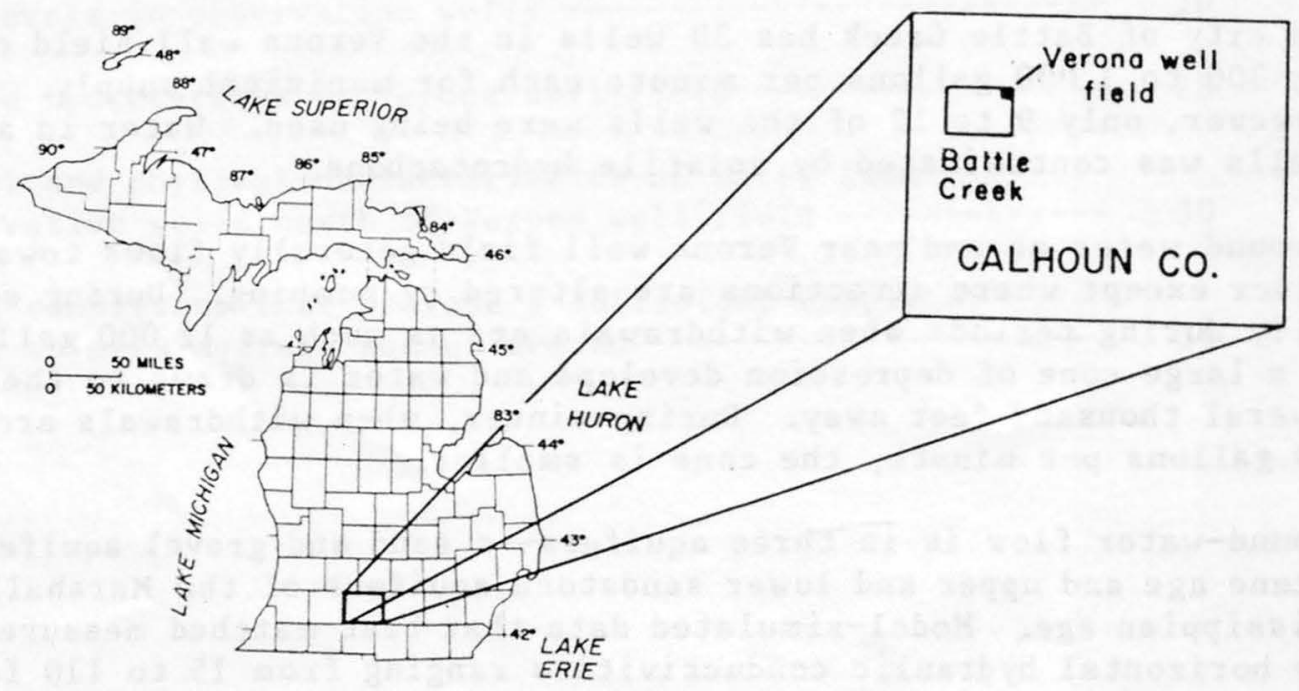

Figure 1.--Location of study area in Calhoun County, Michigan.

\section{PURPOSE AND SCOPE}

This report describes the results of a study to determine (1) the geohydrology and the direction and rate of ground-water flow at and near the Verona well field, (2) how pumping affects flow, (3) the feasibility and effect of installing new supply wells north of the present field, and (4) pumping conditions needed to provide a sufficient supply of potable water. To more accurately evaluate ground-water conditions the study area was extended beyond the immediate vicinity of the well field.

\footnotetext{
Commonly referred to as "field" in this report.
} 


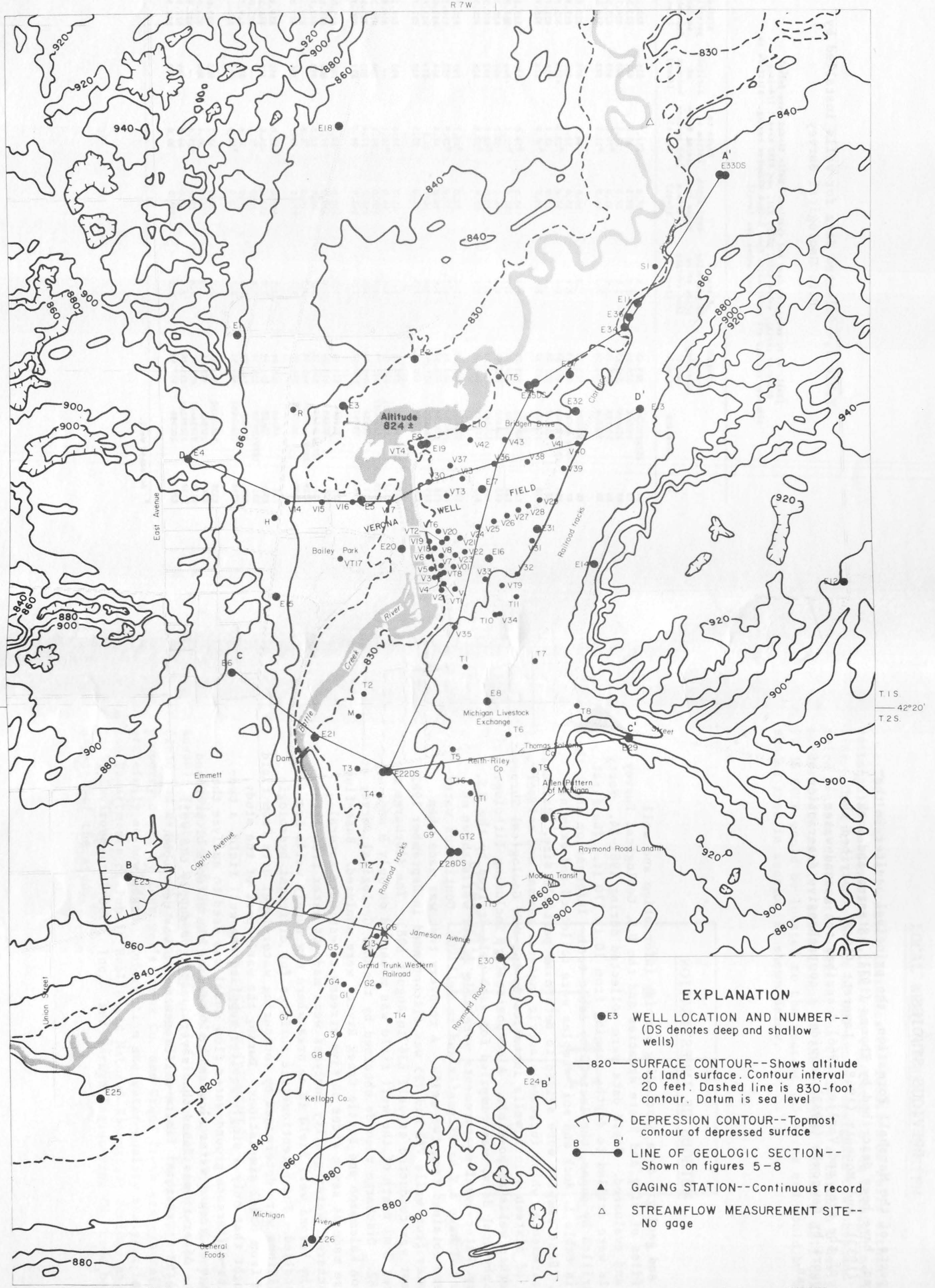

Bose from US Geological Survey 124.000 audrangle
ond and city of Batlle Creek topoaraphic maps 
Various aspects of the Marshall Formation, the principal aquifer in the Battle Creek area, have been described by Thomas (1931), Stearns and Cook (1931), Stearns (1933), and Monnett (1948). Leverett (1918) described the glacial geology of the area and Vanlier (1966) described the ground-water resources. A report by Newcombe (1933) provides a comprehensive description of rocks in Michigan.

\section{METHODS OF INVESTIGATION}

Hydrologic and geologic data, including pumping information and well records in the files of city and State agencies and the U.S. Geological Survey were assembled and evaluated. Field data were collected during 1981-84. Forty observation wells were drilled to depths ranging from 10 to $170 \mathrm{ft}$. The first 20 wells were drilled by auger, the last 20 by cable tool. Information about the wells is given in table 1 . Rock and soil samples were collected and examined during drilling. Some samples were seived to determine particle size. Borehole geophysical measurements, which included electric, natural gamma, and caliper logs, were made of sixteen 4-inch wells installed by the U.S. Geological Survey and of as many other wells as possible. A composite log, including lithologic and borehole geophysical data, was compiled for each well drilled by the U.S. Geological Survey, Water-level measurements were made in all wells shown on figure 2 that do not have a V or VT prefix and in well V01. Continuous waterlevel records were obtained from two wells. A recovery test was made when withdrawal of water from wells V32 and V35 was discontinued in September 1982 and a pumping test was conducted at well E36 in August 1983. The discharge of Battle Creek River $2 \mathrm{mi}$ north of the well field was measured on July 9 and September 7, 1982. Discharge records obtained by the U.S. Geological Survey at gaging stations on Kalamazoo and Battle Creek Rivers were analyzed. Base-flow measurements were made at seven sites on five streams to estimate natural ground-water discharge. Water-quality analyses were made of water from three wells north of the Verona well field in an area where new supply wells are likely to be installed. The potentiometric surfaces for different hydrologic and pumping conditions were determined by contouring water-level data from field measurements and from model simulations. During the early part of the study, when it was thought that only a single aquifer supplied the well field, a twodimensional finite-difference ground-water flow model was used to analyze the effects of pumpage on ground-water flow and to determine the effects of proposed remedial actions. After it was found that several aquifers supply the well field, a quasi three-dimensional finite-difference model was developed.

Table 1.---Selected data for wells installed by U.S. Geological Survey

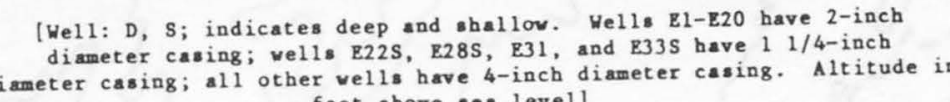

\begin{tabular}{|c|c|c|c|c|c|c|c|}
\hline tel1 & Location & $\begin{array}{c}\text { Altitude } \\
\text { of } \\
\text { measuring } \\
\text { point } \\
\text { (feet) }\end{array}$ & $\begin{array}{l}\text { Distance } \\
\text { of measururing } \\
\text { point above } \\
\text { land surf face } \\
\text { (feet) }\end{array}$ & $\begin{array}{l}\text { Well depth } \\
\text { belov land } \\
\text { burface } \\
\text { (feet) }\end{array}$ & 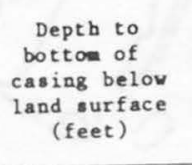 & $\begin{array}{l}\text { Altitude } \\
\text { of } \\
\text { bedrock } \\
\text { (feet) }\end{array}$ & $\begin{array}{l}\text { Altitude of } \\
\text { potentionetric } \\
\text { surf tace on } \\
\text { sertere on } \\
\text { seterber } 1983 \\
\text { (feet) }\end{array}$ \\
\hline & 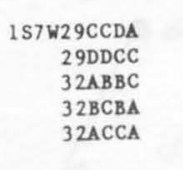 & $\begin{array}{l}865.42 \\
829.66 \\
830.73 \\
883.16 \\
831.54\end{array}$ & $\begin{array}{l}2.3 \\
0.9 \\
3.6 \\
2.0 \\
2.0\end{array}$ & $\begin{array}{l}57.0 \\
28.5 \\
27.5 \\
81.0 \\
14.0\end{array}$ & $\begin{array}{l}a_{51.7} \\
26.6 \\
23.4 \\
a_{70.0} \\
a_{11.0}\end{array}$ & $\begin{array}{l}815 \\
802 \\
800 \\
803 \\
822\end{array}$ & $\begin{array}{l}828.22 \\
823.34 \\
824.79 \\
823.50 \\
819.62\end{array}$ \\
\hline & 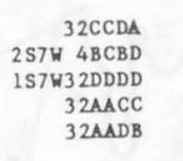 & $\begin{array}{l}875.33 \\
868.28 \\
847.89 \\
831.48 \\
835.92\end{array}$ & $\begin{array}{l}.3 \\
2.1 \\
2.6 \\
.9 \\
2.0\end{array}$ & $\begin{array}{l}60.0 \\
55.0 \\
31.0 \\
17.0 \\
35.0\end{array}$ & $\begin{array}{l}44.7 \\
51.9 \\
3_{28.9} 1.9 \\
a_{30.0} 5.1\end{array}$ & $\begin{array}{c}828 \\
836 \\
6814 \\
8816 \\
824\end{array}$ & $\begin{array}{l}822.88 \\
837.86 \\
825.26 \\
821.73 \\
816.92\end{array}$ \\
\hline & $\begin{array}{l}28 \mathrm{2} C \mathrm{CAC} \\
33 \mathrm{DANA} \\
33 \mathrm{BAAC} \\
33 \mathrm{BSAD} \\
32 \mathrm{CACA}\end{array}$ & $\begin{array}{l}882.02 \\
907.43 \\
856.44 \\
878.79 \\
848.38\end{array}$ & $\begin{array}{l}3.3 \\
1.9 \\
3.8 \\
2.2 \\
2.1\end{array}$ & $\begin{array}{r}43.0 \\
100.0 \\
54.0 \\
70.0 \\
37.0\end{array}$ & 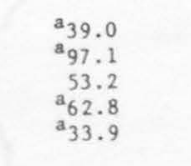 & $\begin{array}{l}<796 \\
<806 \\
801 \\
832 \\
826\end{array}$ & $\begin{array}{l}823.35 \\
867.84 \\
820.13 \\
820.58 \\
823.38\end{array}$ \\
\hline & $\begin{array}{l}32 D A A D \\
32 D A D D \\
29 A C B B \\
32 A C C C \\
32 D B A A\end{array}$ & $\begin{array}{l}834.97 \\
835.84 \\
848.92 \\
831.86 \\
830.44\end{array}$ & $\begin{array}{l}1.8 \\
1.7 \\
3.6 \\
1.4 \\
2.5\end{array}$ & $\begin{array}{l}42.0 \\
32.0 \\
24.0 \\
34.0 \\
21.0\end{array}$ & $\begin{array}{l}\mathbf{a}_{29.7} \\
\mathrm{a}_{27.8} \\
27.4 \\
24.6 \\
13.5\end{array}$ & $\begin{array}{l}797 \\
830 \\
834 \\
819 \\
820\end{array}$ & $\begin{array}{l}820.78 \\
818.12 \\
832.65 \\
821.76 \\
821.72\end{array}$ \\
\hline $\begin{array}{l}2821 \\
2822 \\
2823 \\
2824\end{array}$ & 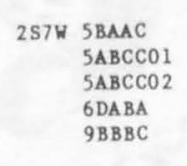 & $\begin{array}{l}831.41 \\
840.21 \\
841.23 \\
849.04 \\
890.42\end{array}$ & $\begin{array}{l}1.4 \\
3.4 \\
4.4 \\
3.6 \\
2.5\end{array}$ & $\begin{array}{r}25.0 \\
14.0 \\
130.0 \\
155.0 \\
163.0\end{array}$ & $\begin{array}{l}16.6 \\
10.6 \\
10.1 \\
55.6 \\
77.4 \\
98.0\end{array}$ & $\begin{array}{l}\frac{815}{800} \\
805 \\
821\end{array}$ & $\begin{array}{l}823.31 \\
824.97 \\
824.38 \\
825.63 \\
850.36\end{array}$ \\
\hline $\begin{array}{l}\text { E25 } \\
\text { E26 } \\
\text { E28 } \\
\text { E28 }\end{array}$ & 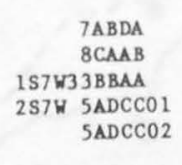 & $\begin{array}{l}825.91 \\
873.04 \\
830.13 \\
840.98 \\
841.99\end{array}$ & $\begin{array}{l}1.8 \\
2.0 \\
2.7 \\
3.2 \\
4.3\end{array}$ & $\begin{array}{r}110.0 \\
135.0 \\
30.0 \\
10.0 \\
130.0\end{array}$ & $\begin{array}{l}58.2 \\
91.0 \\
18.0 \\
86.8 \\
49.7\end{array}$ & $\begin{array}{l}787 \\
806 \\
813 \\
796\end{array}$ & $\begin{array}{l}815.02 \\
816.63 \\
822.70 \\
829.38 \\
828.06\end{array}$ \\
\hline $\begin{array}{l}8 \mathrm{~B} 29 \\
\mathrm{~B} 230 \\
\mathrm{~B} 31 \\
\mathrm{~B} 32 \\
\mathrm{~B} 33 \mathrm{~S}\end{array}$ & 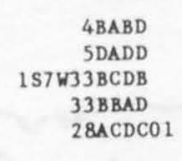 & $\begin{array}{l}866.06 \\
861.58 \\
835.79 \\
844.39 \\
845.53\end{array}$ & $\begin{array}{l}2.5 \\
2.0 \\
3.4 \\
1.6 \\
2.7\end{array}$ & $\begin{aligned} 156.0 \\
139.0 \\
130.0 \\
60.0 \\
18.0\end{aligned}$ & $\begin{array}{r}52.0 \\
104.0 \\
36.6 \\
36.4 \\
x_{115.3}\end{array}$ & $\begin{array}{l}856 \\
769 \\
818 \\
-7\end{array}$ & $\begin{array}{r}839.97 \\
846.22 \\
<82.20 \\
889.26 \\
825.18\end{array}$ \\
\hline $\begin{array}{l}35 \\
34 \\
355 \\
36\end{array}$ & 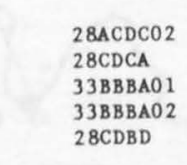 & $\begin{array}{l}845.50 \\
838.45 \\
8333.80 \\
833.36 \\
837.65\end{array}$ & $\begin{array}{l}2.7 \\
2.9 \\
2.9 \\
2.5 \\
2.2\end{array}$ & $\begin{array}{r}170.0 \\
1555.0 \\
221.0 \\
81.0 \\
125.0\end{array}$ & $\begin{array}{r}43.3 \\
79.1 \\
217.1 \\
49.5 \\
39.0 \\
80.0\end{array}$ & $\begin{array}{l}809 \\
806 \\
795 \\
798\end{array}$ & $\begin{array}{l}825.67 \\
821.94 \\
822.81 \\
822.98 \\
822.36\end{array}$ \\
\hline
\end{tabular}




\section{LOCAL WELL NUMBERING SYSTEM}

The local well number indicates the location of wells within the rectangular subdivision of land with reference to the Michigan meridian and base line. The first two segments of the number designate township and range, the third segment designates section, and the letters A through D designate successively smaller subdivisions of the section. Thus, a well designated as $1 \mathrm{~S}$ $7 \mathrm{~W} 16$ CCCB would be located to the nearest 2.5 acres and would be within the shaded area in section 16 shown below.

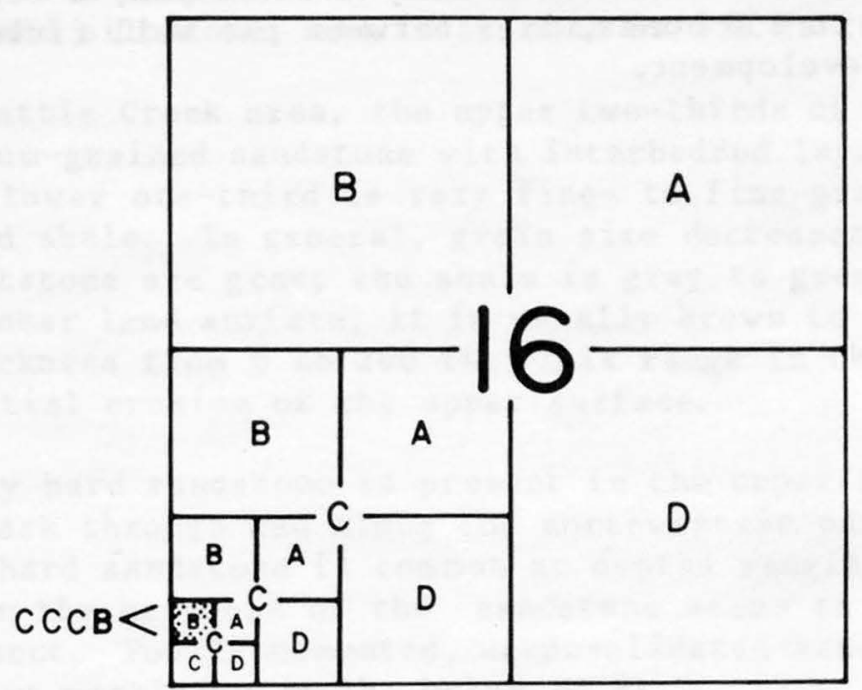

\section{ACKNOWLEDGMENTS}

Employees of the city of Battle Creek, especially Mr. Larry Osborn and Mr. Russell Schuler, have been most helpful in providing information about the well field and assistance in other phases of the study. Permission to drill wells on property owned by Consumer's Power Co. and Grand Trunk Western Railroad Co. is gratefully acknowledged. Information and water-quality analyses from the Michigan Departments of Public Health and Natural Resources; Ecology and Environment, Inc.; Environmental Data, Inc.; and Warzyn Engineering Co. have been helpful in aspects of the study. 


\section{PHYSICAL SETTING}

The valley of Battle Creek River is $1 \mathrm{mi}$ wide at Verona well field and has altitudes ranging from 824 to $840 \mathrm{ft}$ (fig. 2). Upstream, the valley is $1.5 \mathrm{mi}$ wide; downstream, it narrows to $0.5 \mathrm{mi}$. The valley walls rise sharply on the east to 910 ft and gradually on the west to about the same altitude. A dam near Emmett St ponds the river at an altitude of $824 \mathrm{ft}$ for a 1.5 -mile reach that passes through the well field. North of the well field, there are no

commercial-industrial developments within the study area. South of the field, however, are eight large and several small companies. A railroad complex, including a switching yard, lies along the east side of the well field and landfill is 1 mi southeast. The Verona Valley Subdivision, a residential section composed of 100 to 150 homes, lies between the well field and the commercial-industrial development.

\section{SOURCES OF WATER}

Water for municipal supplies and most commercial-industrial activity is pumped from wells that tap sandstones in the Marshall Formation; most of these wells are 100 to $160 \mathrm{ft}$ deep. Large-diameter wells in the sandstone can yield several thousand gallons per minute.

The city of Battle Creek municipal supply wells range in depth from 110 $152 \mathrm{ft}$ (table 2). Sixteen of these wells consistently yield $1,000 \mathrm{gal} / \mathrm{min}$. From 1970 through 1981, average pumpage by the city was about $5,000 \mathrm{gal} / \mathrm{m}$. During 1982, average pumpage was $8,300 \mathrm{gal} / \mathrm{min}$; during 1983 it was 6,650 gal/min. During periods of peak pumping, 12,000 to 14,000 it was 6,650 withdrawn.

In the past, water for residential supplies in the Verona Valley Subdivision was obtained from 20- to 60-foot deep wells in the Marshall Formation and the overlying glacial deposits. Today (1985) most residences are connected to the Battle Creek municipal system

Table 2.--Selected data for city of Battle Creek's wells

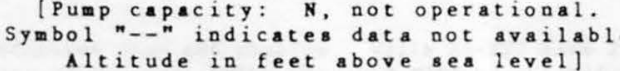

\begin{tabular}{|c|c|c|c|c|c|c|c|}
\hline $\begin{array}{c}\text { We11 } \\
\text { number } \\
\text { number }\end{array}$ & $\begin{array}{c}\text { Altitude } \\
\text { of } \\
\text { land surface } \\
\text { (feet) }\end{array}$ & $\begin{array}{l}\text { Yell dept } \\
\text { belou land } \\
\text { surtace } \\
\text { (feet) }\end{array}$ & $\begin{array}{l}\text { Dottom } \\
\text { casing belou } \\
\text { and surface } \\
\text { (feet) }\end{array}$ & $\begin{array}{l}\text { Dismeter } \\
\text { of } \\
\text { casing } \\
\text { (inches) }\end{array}$ & $\begin{array}{l}\text { Altitude } \\
\text { of top } \\
\text { of bed rock } \\
\text { (feet) }\end{array}$ & 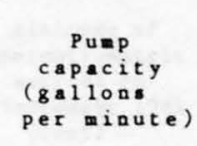 & \\
\hline $\begin{array}{l}\mathbf{v} 1 \\
\text { V2 }\end{array}$ & $\begin{array}{l}836 \\
834\end{array}$ & $\begin{array}{l}124 \\
124\end{array}$ & $\begin{array}{r}45 \\
44\end{array}$ & $\begin{array}{c}10 \\
8\end{array}$ & $\begin{array}{l}793 \\
8802\end{array}$ & ${ }_{N}^{N}$ & $\begin{array}{l}1915 \\
1915\end{array}$ \\
\hline $\begin{array}{l}73 \\
74 \\
74\end{array}$ & $\begin{array}{l}830 \\
830\end{array}$ & $\begin{array}{l}113 \\
129\end{array}$ & $\begin{array}{l}47 \\
47 \\
60\end{array}$ & $\begin{array}{r}8 \\
10 \\
6\end{array}$ & $\begin{array}{l}800 \\
800 \\
800\end{array}$ & N & $\begin{array}{l}1918 \\
1990\end{array}$ \\
\hline & & & & $\begin{array}{l}6 \\
10^{\circ}\end{array}$ & $\begin{array}{l}8000 \\
815\end{array}$ & & $\begin{array}{l}1915 \\
1915\end{array}$ \\
\hline $\begin{array}{l}\text { v6 } \\
\text { v7 }\end{array}$ & $\begin{array}{l}831 \\
833\end{array}$ & $\begin{array}{l}121 \\
126\end{array}$ & $\begin{array}{l}50 \\
52\end{array}$ & $\begin{array}{l}6 \\
8\end{array}$ & $\begin{array}{l}816 \\
806\end{array}$ & ${ }_{N}^{N}$ & $\begin{array}{l}1913 \\
1915\end{array}$ \\
\hline $\begin{array}{l}\text { v8 } \\
\text { v13 }\end{array}$ & $\begin{array}{r}833 \\
836\end{array}$ & 121 & 32 & 8 & 819 & N & $\begin{array}{l}1913 \\
19113\end{array}$ \\
\hline v14 & $\begin{array}{l}836 \\
840 \\
840\end{array}$ & $\begin{array}{l}127 \\
129\end{array}$ & $\begin{array}{l}18 \\
39 \\
39\end{array}$ & $\begin{array}{l}12 \\
12\end{array}$ & $\begin{array}{l}822 \\
802\end{array}$ & $\begin{array}{l}1000 \\
1000\end{array}$ & $\begin{array}{l}1936 \\
1939\end{array}$ \\
\hline $\begin{array}{l}\text { V15 } \\
\text { v16 }\end{array}$ & 836 & 141 & -- & 12 & 804 & 1000 & 1939 \\
\hline $\begin{array}{l}\mathbf{V} 16 \\
\text { v17 }\end{array}$ & $\begin{array}{l}834 \\
831\end{array}$ & $\begin{array}{l}134 \\
133\end{array}$ & 33 & $\begin{array}{l}12 \\
12\end{array}$ & $\begin{array}{l}812 \\
824\end{array}$ & $\begin{array}{l}750 \\
\text { N }\end{array}$ & $\begin{array}{l}1939 \\
1939\end{array}$ \\
\hline $\begin{array}{l}\nabla 18 \\
\nabla 19\end{array}$ & $\begin{array}{l}833 \\
832\end{array}$ & $\begin{array}{l}126 \\
125\end{array}$ & $\begin{array}{l}46 \\
48\end{array}$ & $\begin{array}{r}10 \\
8\end{array}$ & $\begin{array}{l}819 \\
817\end{array}$ & $\begin{array}{l}500 \\
300\end{array}$ & $\begin{array}{l}1915 \\
1915\end{array}$ \\
\hline $\begin{array}{l}\nabla 20 \\
\nabla 221 \\
\nabla\end{array}$ & $\begin{array}{l}834 \\
834\end{array}$ & $\begin{array}{l}140 \\
131\end{array}$ & $\begin{array}{l}21 \\
44\end{array}$ & $\begin{array}{l}8 \\
8\end{array}$ & $\begin{array}{l}822 \\
822\end{array}$ & $\begin{array}{l}300 \\
300\end{array}$ & $\begin{array}{l}1904 \\
1995\end{array}$ \\
\hline $\begin{array}{l}\text { v22 } \\
\text { v223 }\end{array}$ & $\begin{array}{l}833 \\
833\end{array}$ & 113 & 77 & 10 & 793 & 750 & $\begin{array}{l}1919 \\
1919\end{array}$ \\
\hline v24 & $\begin{array}{l}832 \\
835\end{array}$ & $\begin{array}{l}110 \\
118\end{array}$ & $\begin{array}{l}46 \\
41\end{array}$ & $\begin{array}{l}8 \\
8\end{array}$ & $\begin{array}{l}973 \\
823\end{array}$ & $\begin{array}{l}3000 \\
300\end{array}$ & $\begin{array}{l}1913 \\
1926\end{array}$ \\
\hline $\begin{array}{l}\nabla 25 \\
\nabla 26 \\
\nabla 26\end{array}$ & $\begin{array}{l}835 \\
836\end{array}$ & $\begin{array}{l}115 \\
115\end{array}$ & $\begin{array}{l}36 \\
38\end{array}$ & $\begin{array}{l}8 \\
8\end{array}$ & $\begin{array}{l}823 \\
825\end{array}$ & $\begin{array}{l}300 \\
300\end{array}$ & $\begin{array}{l}1926 \\
1996\end{array}$ \\
\hline $\begin{array}{l}\text { V27 } \\
\text { v28 }\end{array}$ & 837 & 116 & $\begin{array}{l}46 \\
46\end{array}$ & 8 & 815 & 300 & $\begin{array}{l}1926 \\
1926\end{array}$ \\
\hline $\begin{array}{l}\nabla_{218} \\
\nabla 29\end{array}$ & $\begin{array}{l}836 \\
835\end{array}$ & $\begin{array}{l}115 \\
121\end{array}$ & $\begin{array}{l}47 \\
51\end{array}$ & $\begin{array}{l}8 \\
8\end{array}$ & $\begin{array}{l}810 \\
800\end{array}$ & $\begin{array}{l}3000 \\
300\end{array}$ & $\begin{array}{l}1926 \\
1926\end{array}$ \\
\hline $\begin{array}{l}\text { V30 } \\
\text { v310 }\end{array}$ & $\begin{array}{l}831 \\
837\end{array}$ & $\begin{array}{l}151 \\
125\end{array}$ & 76 & $\begin{array}{r}8 \\
16\end{array}$ & $\begin{array}{l}796 \\
784\end{array}$ & $\begin{array}{r}500 \\
1000\end{array}$ & $\begin{array}{l}1904 \\
1994\end{array}$ \\
\hline $\begin{array}{l}\text { v31 } \\
\text { v323 }\end{array}$ & 838 & $\begin{array}{l}120 \\
120\end{array}$ & 57 & 16 & 794 & $\begin{array}{l}1000 \\
1000\end{array}$ & $\begin{array}{l}1948 \\
1948\end{array}$ \\
\hline v34 & $\begin{array}{l}837 \\
840\end{array}$ & $\begin{array}{l}130 \\
140\end{array}$ & $\begin{array}{l}49 \\
67\end{array}$ & $\begin{array}{l}16 \\
16\end{array}$ & $\begin{array}{l}912 \\
792\end{array}$ & $\begin{array}{l}1000 \\
1000\end{array}$ & $\begin{array}{l}1948 \\
1948\end{array}$ \\
\hline $\begin{array}{l}735 \\
\text { v36 }\end{array}$ & $\begin{array}{l}840 \\
840\end{array}$ & $\begin{array}{l}132 \\
147\end{array}$ & $\begin{array}{r}59 \\
44\end{array}$ & $\begin{array}{l}16 \\
16\end{array}$ & $\begin{array}{l}805 \\
8852\end{array}$ & $\begin{array}{l}1000 \\
1000\end{array}$ & $\begin{array}{l}1948 \\
19957\end{array}$ \\
\hline $\begin{array}{l}730 \\
7373\end{array}$ & 832 & $\begin{array}{l}147 \\
145\end{array}$ & $\begin{array}{l}44 \\
44\end{array}$ & $\begin{array}{l}10 \\
16\end{array}$ & $\begin{array}{l}8253 \\
817\end{array}$ & $\begin{array}{l}1000 \\
1000\end{array}$ & $\begin{array}{l}1957 \\
1957\end{array}$ \\
\hline $\begin{array}{l}\nabla 38 \\
\nabla 39\end{array}$ & $\begin{array}{l}838 \\
839\end{array}$ & $\begin{array}{l}152 \\
145\end{array}$ & 37 & $\begin{array}{l}16 \\
16\end{array}$ & $\begin{array}{l}823 \\
812\end{array}$ & $\begin{array}{l}1000 \\
1000\end{array}$ & $\begin{array}{l}1959 \\
1960\end{array}$ \\
\hline $\begin{array}{r}740 \\
741\end{array}$ & $\begin{array}{l}842 \\
840\end{array}$ & $\begin{array}{l}148 \\
147\end{array}$ & $\begin{array}{l}42 \\
44\end{array}$ & $\begin{array}{l}16 \\
16\end{array}$ & $\begin{array}{l}812 \\
822\end{array}$ & $\begin{array}{l}1000 \\
1000\end{array}$ & $\begin{array}{l}1962 \\
1962\end{array}$ \\
\hline $\begin{array}{l}742 \\
743\end{array}$ & $\begin{array}{l}833 \\
835\end{array}$ & $\begin{array}{l}150 \\
148\end{array}$ & $\overline{26}$ & $\begin{array}{r}16 \\
6\end{array}$ & $\overline{827}$ & $\begin{array}{l}1000 \\
1000\end{array}$ & $\begin{array}{l}1968 \\
1996\end{array}$ \\
\hline
\end{tabular}


Table 2.--Selected data for city of

Battle Creek's wells--Continued

Test ve11s

\begin{tabular}{|c|c|c|c|c|c|c|c|}
\hline $\begin{array}{c}\begin{array}{c}\text { heel1 } \\
\text { number }\end{array} \\
\text { aumber }\end{array}$ & $\begin{array}{l}\text { Altitude } \\
\text { of } \\
\text { ondurface } \\
\text { (feet) }\end{array}$ & $\begin{array}{l}\text { Well depth } \\
\text { belov land } \\
\text { surface } \\
\text { (feet) }\end{array}$ & 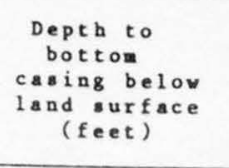 & $\begin{array}{c}\text { Dianeter } \\
\text { of } \\
\text { ofing } \\
(\text { inches })\end{array}$ & $\begin{array}{l}\text { Altitude } \\
\text { of top } \\
\text { of bedrock } \\
\text { (feet) }\end{array}$ & $\begin{array}{c}\text { Pump } \\
\text { capacity } \\
\text { (gallons } \\
\text { perainute) }\end{array}$ & $\begin{array}{c}\text { Year } \\
\text { drilled }\end{array}$ \\
\hline $\begin{array}{l}\text { vit } \\
\text { vit1 } \\
\text { vit2 } \\
\text { vit3 } \\
\text { vit4 }\end{array}$ & $\begin{array}{l}834 \\
834 \\
834 \\
834 \\
828\end{array}$ & $\begin{array}{l}40 \\
48 \\
70 \\
75 \\
76\end{array}$ & $\begin{array}{l}\because \\
\because z \\
z\end{array}$ & $\begin{array}{l}2 \\
2 \\
2 \\
2 \\
2\end{array}$ & $\begin{array}{l}790 \\
790 \\
820 \\
828 \\
820\end{array}$ & $\begin{array}{l}-- \\
-\because \\
--\end{array}$ & $\begin{array}{l}1903 \\
1903 \\
1903 \\
1903 \\
1903\end{array}$ \\
\hline $\begin{array}{l}\text { VTS } \\
\text { VT5A } \\
\text { VT6 } \\
\text { VT7 } \\
\text { VT8 }\end{array}$ & $\begin{array}{l}833 \\
833 \\
830 \\
834 \\
830\end{array}$ & $\begin{array}{r}50 \\
55 \\
95 \\
95 \\
142 \\
27\end{array}$ & $\begin{array}{l}-- \\
10 \\
---\end{array}$ & $\begin{array}{r}2 \\
2 \\
6 \\
-2 \\
-2\end{array}$ & $\begin{array}{l}-- \\
825 \\
---\end{array}$ & $\begin{array}{l}-- \\
z= \\
z-\end{array}$ & $\begin{array}{l}1903 \\
1903 \\
1903 \\
1904 \\
1904\end{array}$ \\
\hline $\begin{array}{l}\text { VT9 } \\
\text { VTr10 } \\
\text { VT11 } \\
\text { VT12 } \\
\text { vT13 } \\
\text { VT13 }\end{array}$ & $\begin{array}{l}838 \\
-38 \\
836 \\
836\end{array}$ & $\begin{array}{r}150 \\
20 \\
49 \\
28 \\
45\end{array}$ & $\begin{array}{l}- \\
-\because \\
-\because- \\
--\end{array}$ & $\begin{array}{l}2 \\
2 \\
2 \\
2 \\
2\end{array}$ & $\begin{array}{l}- \\
79 . \\
778\end{array}$ & $\begin{array}{l}-- \\
-- \\
\overline{-} \\
--\end{array}$ & $\begin{array}{l}1904 \\
1904 \\
1904 \\
1904 \\
1904 \\
1904 \\
1904\end{array}$ \\
\hline $\begin{array}{l}\text { vT14 } \\
\text { vT15 } \\
\text { vT16 } \\
\text { vT17 } \\
\text { vT18 }\end{array}$ & $\begin{array}{l}838 \\
836 \\
832 \\
833 \\
832\end{array}$ & $\begin{array}{l}53 \\
38 \\
27 \\
71 \\
51\end{array}$ & $\begin{array}{l}-: \\
\overline{-} \\
\overline{-}\end{array}$ & $\begin{array}{l}2 \\
2 \\
2 \\
2 \\
2\end{array}$ & $\begin{array}{l}798 \\
804 \\
820 \\
827 \\
802\end{array}$ & $\begin{array}{l}-- \\
=- \\
-=\end{array}$ & $\begin{array}{l}1904 \\
1904 \\
1904 \\
1905 \\
1905\end{array}$ \\
\hline $\begin{array}{l}\text { VT19 } \\
\text { VTI20 } \\
\text { VT21 } \\
\text { VT22 } \\
\text { VT 23 }\end{array}$ & $\begin{array}{l}-- \\
\because- \\
z-\end{array}$ & $\begin{array}{l}29 \\
16 \\
18 \\
16 \\
18\end{array}$ & $\begin{array}{l}-- \\
\because= \\
z\end{array}$ & $\begin{array}{l}2 \\
2 \\
2 \\
2 \\
2\end{array}$ & $\begin{array}{l}- \\
-\because \\
--\end{array}$ & $\begin{array}{l}=- \\
\because= \\
z\end{array}$ & $\begin{array}{l}1905 \\
1913 \\
1913 \\
1913 \\
1913\end{array}$ \\
\hline $\begin{array}{l}\text { VT24 } \\
\text { VT2125 } \\
\text { VTT26 } \\
\text { VT27 } \\
\text { VT28 }\end{array}$ & $\begin{array}{l}833 \\
=- \\
=- \\
--\end{array}$ & $\begin{array}{l}34 \\
27 \\
25 \\
27 \\
20\end{array}$ & $\begin{array}{l}z- \\
z= \\
z-\end{array}$ & $\begin{array}{l}2 \\
2 \\
2 \\
2 \\
2\end{array}$ & $\begin{array}{l}816 \\
-- \\
-- \\
--\end{array}$ & $\begin{array}{l}-- \\
\ddot{z} \\
--\end{array}$ & $\begin{array}{l}1913 \\
1913 \\
1913 \\
1913 \\
1913\end{array}$ \\
\hline $\begin{array}{l}\text { VT29 } \\
\mathrm{VTT30} \\
\mathrm{VTT31} \\
\mathrm{VT} 32\end{array}$ & $\begin{array}{l}-\overline{-} \\
833 \\
\overline{831}\end{array}$ & $\begin{array}{l}35 \\
25 \\
29 \\
46\end{array}$ & $\begin{array}{l}-- \\
-z \\
--\end{array}$ & $\begin{array}{l}2 \\
2 \\
2 \\
2\end{array}$ & $\begin{array}{l}\overline{819} \\
\overline{8198}\end{array}$ & $\begin{array}{l}=- \\
=-\end{array}$ & $\begin{array}{l}1913 \\
1913 \\
1913 \\
1913\end{array}$ \\
\hline VT33 & $\begin{array}{l}831 \\
8331\end{array}$ & $\begin{array}{l}46 \\
61\end{array}$ & $\bar{~}=$ & $\begin{array}{l}2 \\
2\end{array}$ & $\begin{array}{l}788 \\
812\end{array}$ & "-- & $\begin{array}{l}1918 \\
1920\end{array}$ \\
\hline $\begin{array}{l}\text { VT37 } \\
\mathrm{VTT38} \\
\mathrm{VTT3} \\
\mathrm{vT440}\end{array}$ & $\begin{array}{l}-\overline{830} \\
836 \\
836\end{array}$ & $\begin{array}{l}59 \\
55 \\
44 \\
40\end{array}$ & $\begin{array}{l}-- \\
-z \\
-z\end{array}$ & $\begin{array}{l}2 \\
2 \\
8 \\
8\end{array}$ & $\begin{array}{l}792 \\
792 \\
816 \\
816\end{array}$ & $\begin{array}{l}=- \\
=- \\
-\end{array}$ & $\begin{array}{l}1920 \\
1921 \\
1904 \\
1904\end{array}$ \\
\hline
\end{tabular}

The 1ithology of the Marshall Formation and glacial deposits in wells installed by the U.S. Geological Survey is given in table 3 (at end of report).

\section{MARSHALL FORMATION}

Lithology and Thicknes

The Marshall Formation underlies much of the Lower Peninsula of Michigan The formation is a very fine to coarse sandstone containing layers of shale, sandy shale, and siltstone, and is as much as $550 \mathrm{ft}$ thick at places.

In the Battle Creek area, the upper two-thirds of the Marshall Formation is fine- to medium-grained sandstone with interbedded layers of siltstone and shale (fig. 3). The lower one-third is very fine- to fine-grained silty sandstone, siltstone, and shale. In general, grain size decreases with depth. The sandstone and siltstone are gray; the shale is gray to greenish gray. Where the formation is near land surface, it is usually brown to yellow. The formation ranges in thickness from 0 to $200 \mathrm{ft}$. This range in thickness results primarily from differential erosion of the upper surface.

Extremely hard sandstone is present in the upper few feet of the formation from Bailey Park through and along the northwestern part of the well field. Hard to very hard sandstone is common at depths ranging from 5 to $60 \mathrm{ft}$. Differences in the hardness of the sandstone seems to be due to differences in amount of cement. Poorly cemented, unconsolidated sandstone has been reported at some places; mostly at depths below $80 \mathrm{ft}$.

A small outcrop of the Marshall Formation is at the eastern foot of the dan on Battle Creek River near Emmett St (fig. 2). Sandstone of the formation was quarried for building stone about $4 \mathrm{mi}$ southeast of the Verona well field.

Major lithologic units of the Marshall Formation defined on figure 3 can be identified on gamma-ray logs for many wells; logs for three wells are shown on figure 4. The principal marker beds in the type column are the upper siltstone and the shale. Geologic sections, figures 5 to 8 show stratigraphic relations of the major units.

The upper sandstone, upper siltstone, and part of the lower sandstone have been eroded near well G6 (figs. 5 and 6 ) and in the southwestern part of the study area. All bedrock units are present, however, in the rest of the area.

Drillers' descriptions of materials in most municipal wells identify the glacial deposits as "sand and gravel" and most of the Marshall Formation as "hard or soft sandstone". A "blue shale" unit is identified at the bottom of many wells (fig. 9). For some wells, notations are made concerning "openings". For several wells, as for V36, a more complete description of the materials is given, revealing that the "sandstone" in some zones is silty and shaly and that a silty or shaly bed was found about half way down the borehole. 


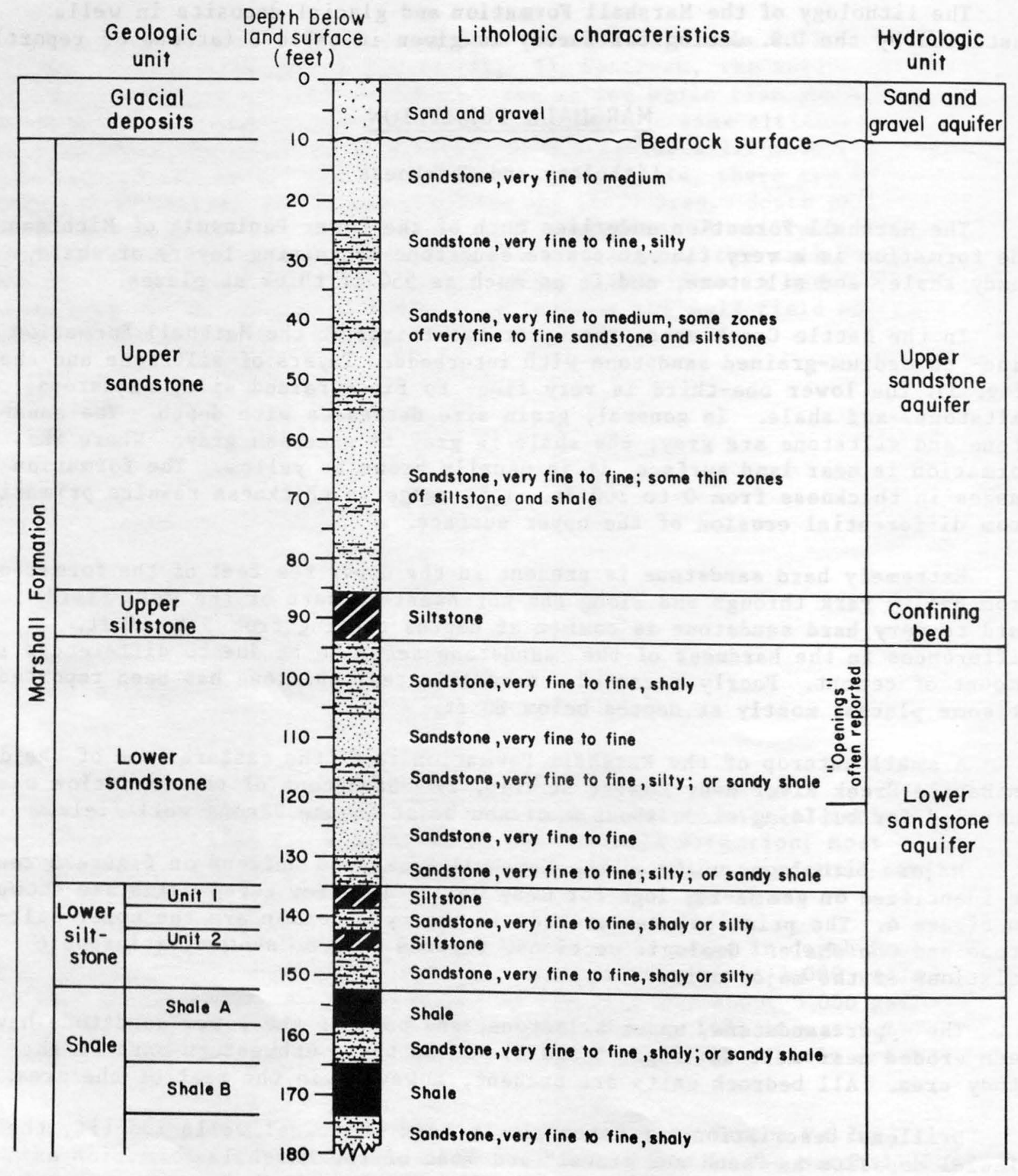

Figure 3.--Type 1ithologic column of Marshall Formation in Verona well field area. 


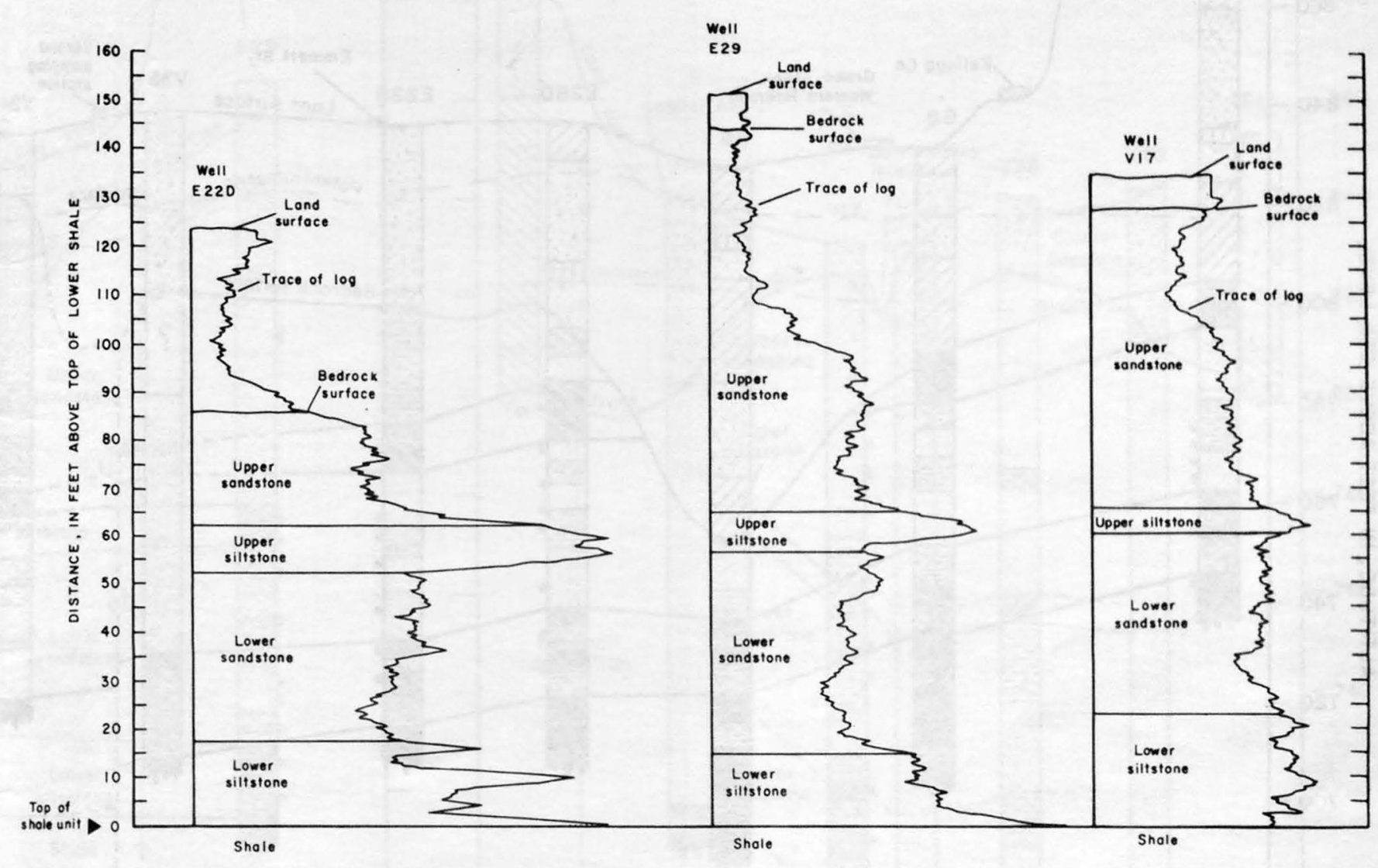

Figure 4.--Units of Marshall Formation identified on gamma-ray logs of several wells (Gamma count increases left to right). 


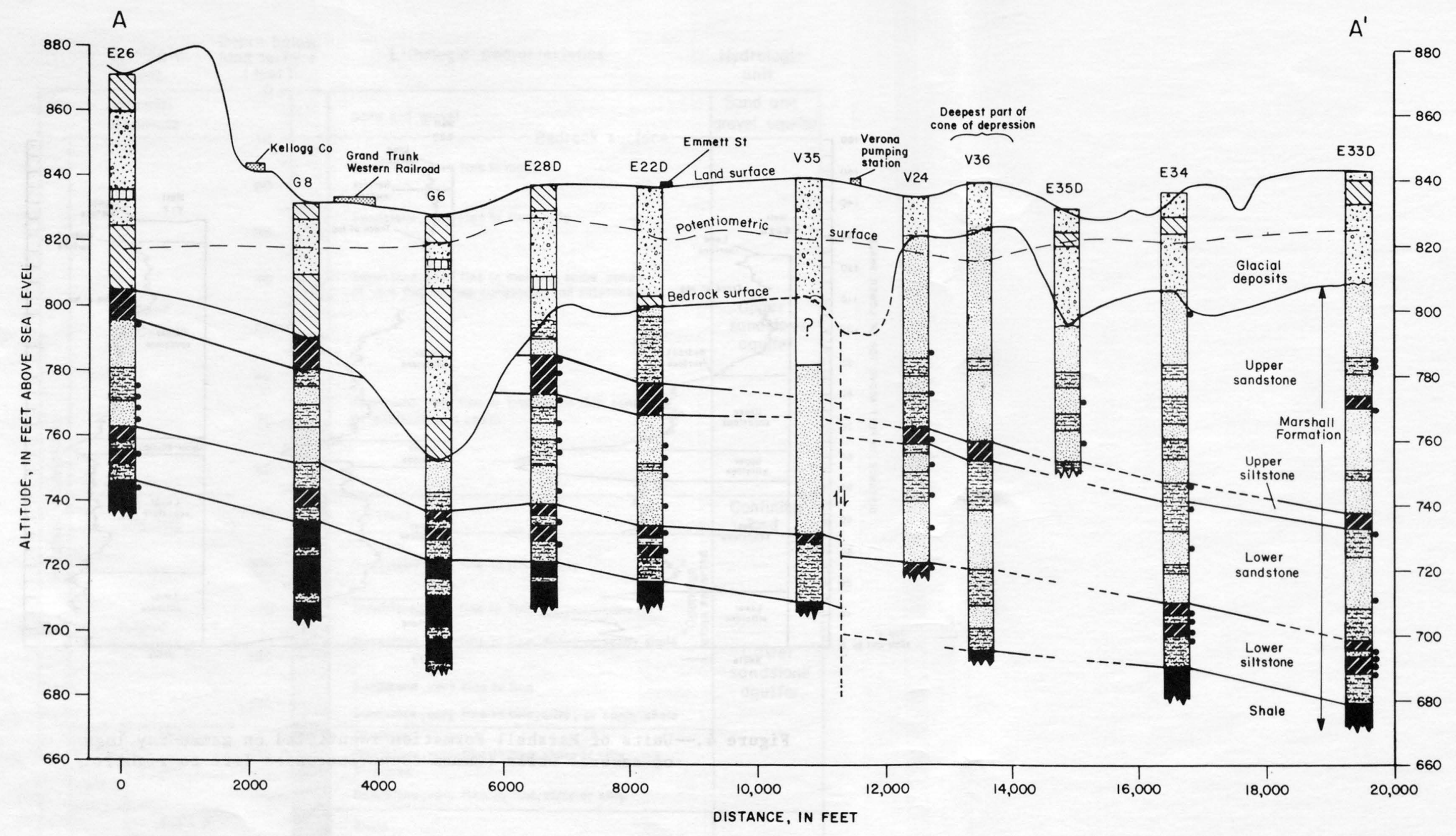

Figure 5.--Geologic section $A-A^{\prime}$, in north-south direction through Verona well field.

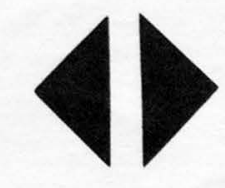

EXPLANATION DESCRIPTION OF LITHOLOGIC UNITS Sand

1... Sond and gravel

$\checkmark$ Sand, grovel, silt, and clay

IIII) Clay

VIV Siltstone

shole

Sandstone, shaly and/or silty

E23 WELL NUMBER

--- LINE OF STRATIGRAPHIC CORRELATION--

- ZONE OF OPENINGS-- as indicated by coliper log

1it INFERRED GEOLOGIC STRUCTURE -- foult, fold,
or lorgo fracture. Arrows show direction of movement (Location of geobogic sections shown in figures 2 ond 12) 


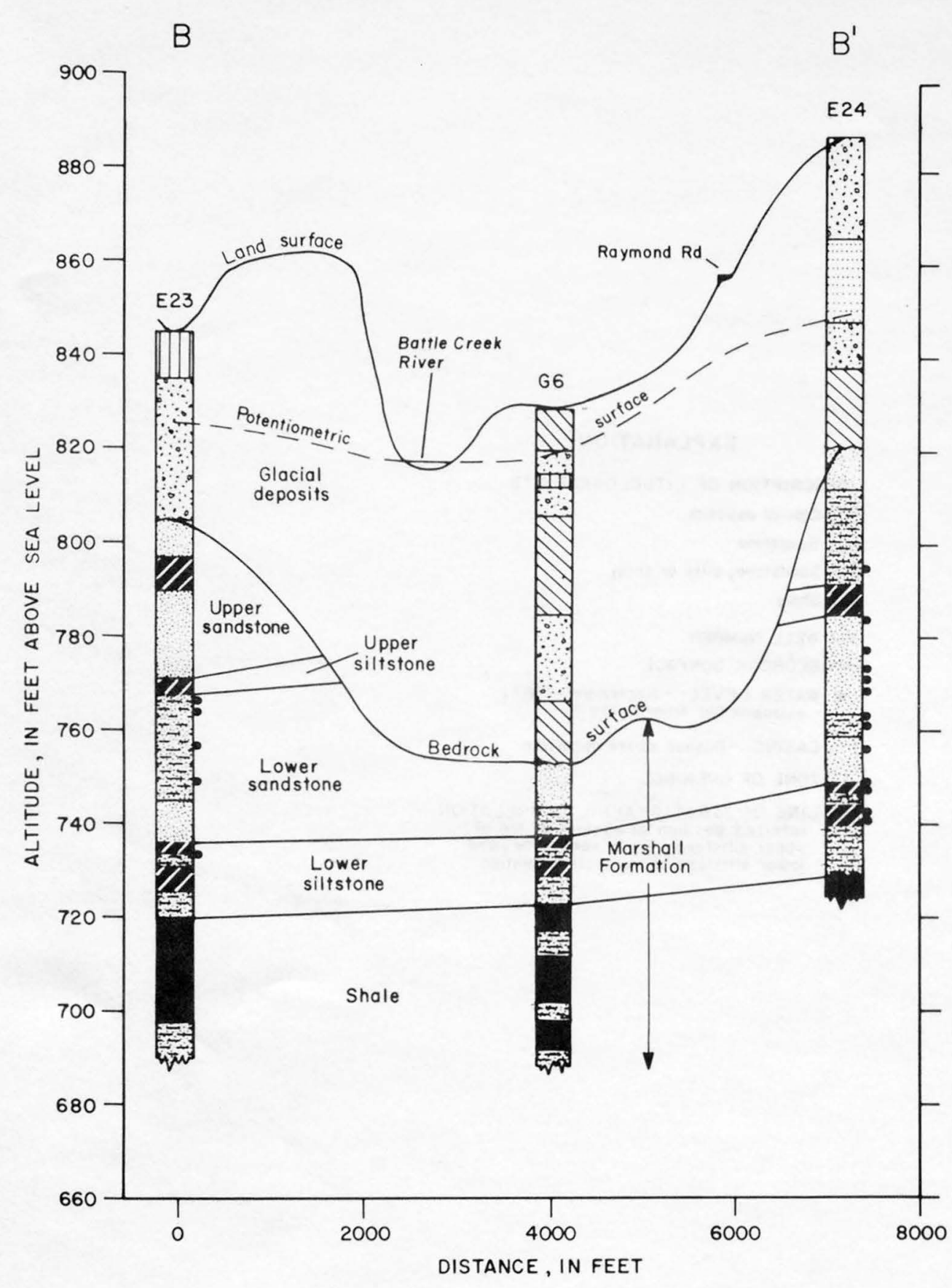

Figure 6.--Geologic section $B-B^{\prime}$, in east-west direction through southern part of study area.

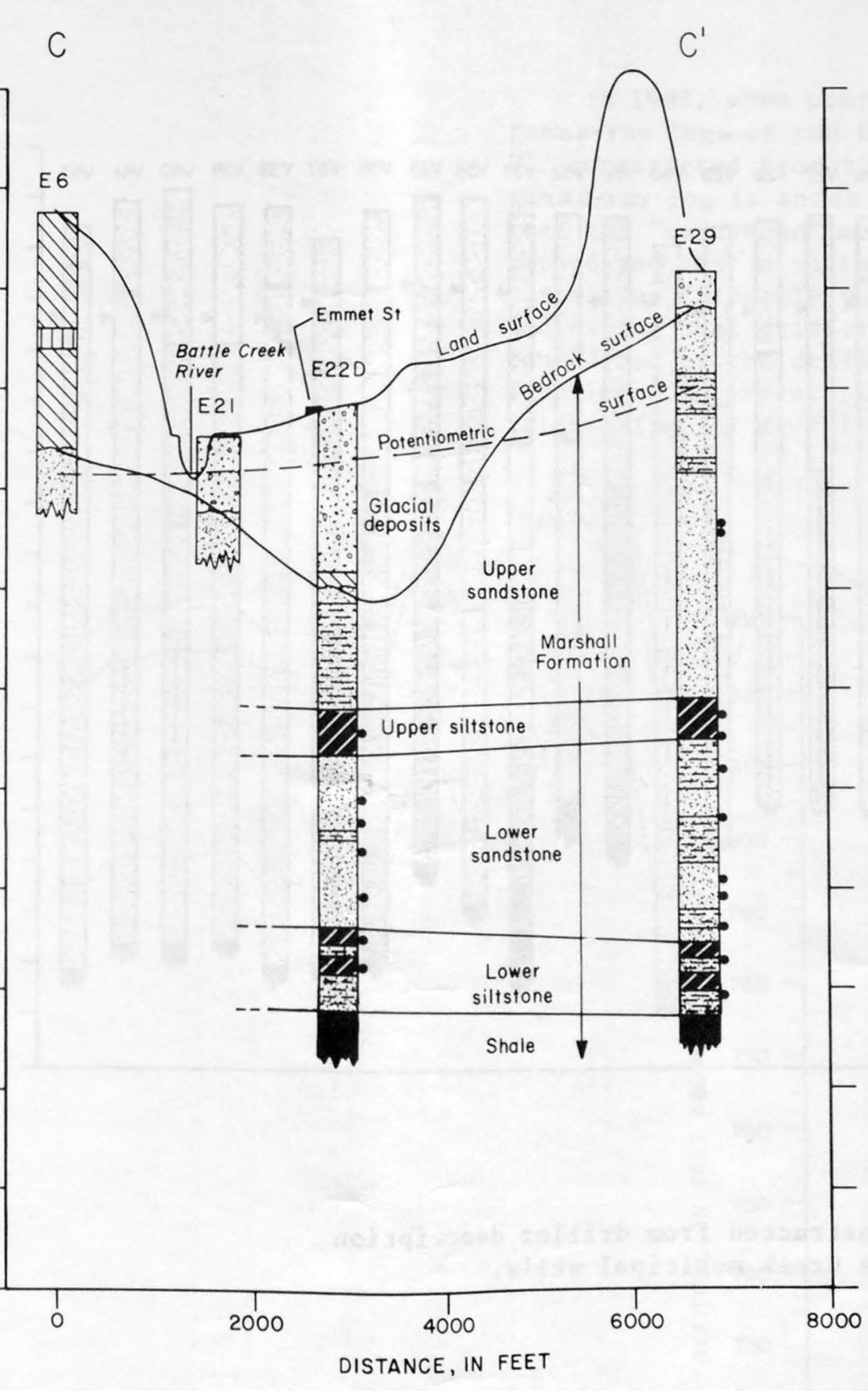

Figure 7.--Geologic section $\mathrm{C}^{-C^{\prime}}$, in east-west direction along Emmett St.

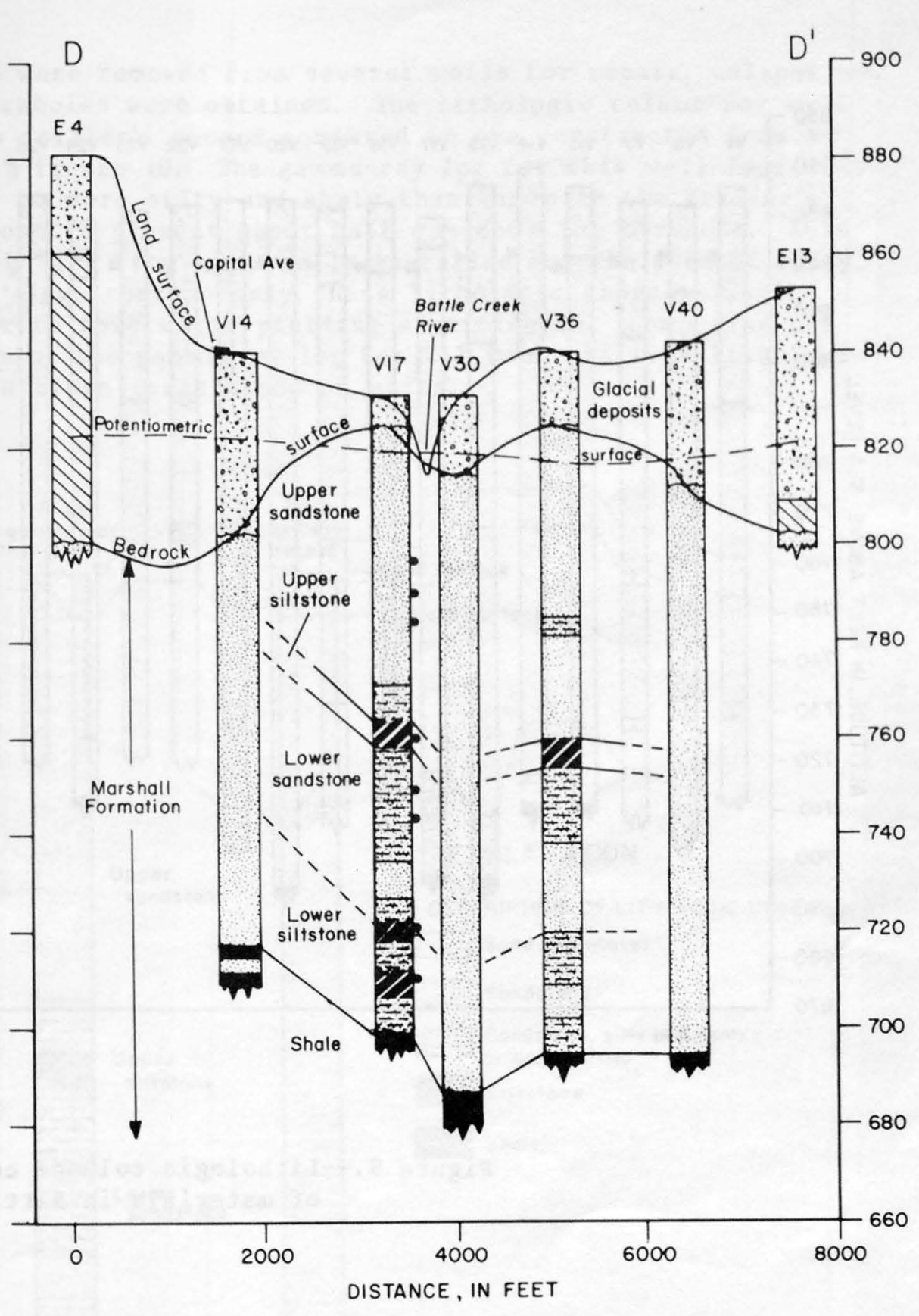

Figure 8.--Geologic section D-D', in east-west direction through Verona well $\mathrm{field}$. 


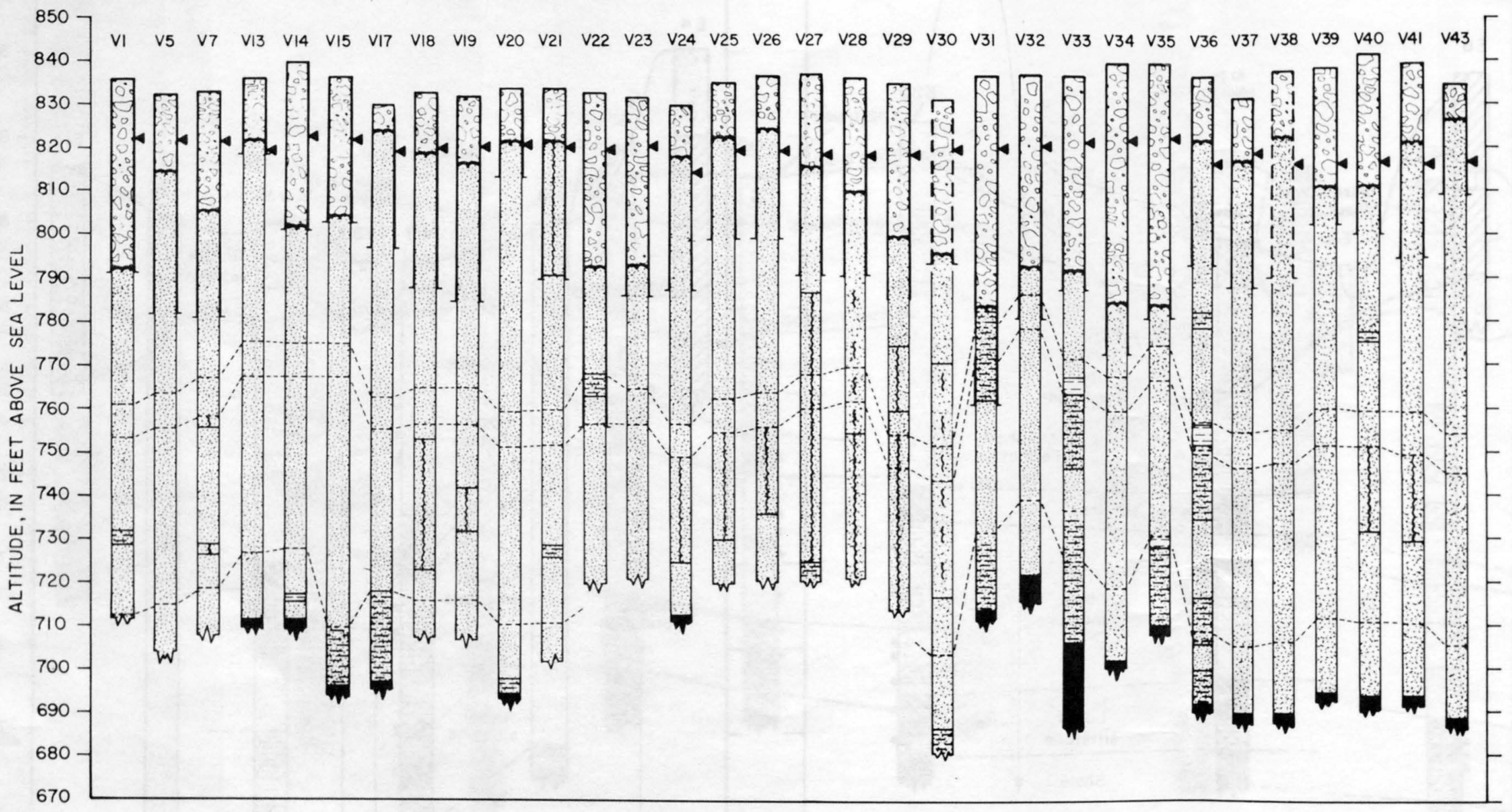

EXPLANATION DESCRIPTION OF LITHOLOGIC UNITS S. Glacial deposits Sandstone, silty or shaly Shale

VIT WELL NUMBER

BEDROCK SURFACE

4 WATER LEVEL-- September 1983 ,

J $L$ CASING -- Dashed where uncertain

ZONE OF OPENINGS

LINE OF STRATIGRAPHIC CORRELATION-

interred position of contoct of top of
upper siltstone, lower sondstone,

lower siltstone of Morsholl Formation

Figure 9.--Lithologic columns constructed from driller description of materials in Battle Creek municipal wells. 
In 1983, when pumps were removed from several wells for repair, caliper and gamma-ray logs of the boreholes were obtained. The lithologic column for well V17 constructed from the driller's record compared to one constructed from a gamma-ray $\log$ is shown in figure 10. The gamma-ray $\log$ for this well indicates that the "sandstone" may be more silty and shaly than shown in the driller's record and that a siltstone is present about half way down the borehole. This correlates favorably with data from many wells installed for the present study, indicating that drillers' logs contain only those lithologic characteristics considered by the driller to have water-yielding significance. Comparing the lithologic interpretation of the gamma-ray $\log$ for V17 with the type lithologic column (fig. 3) reveals a close correlation of units.

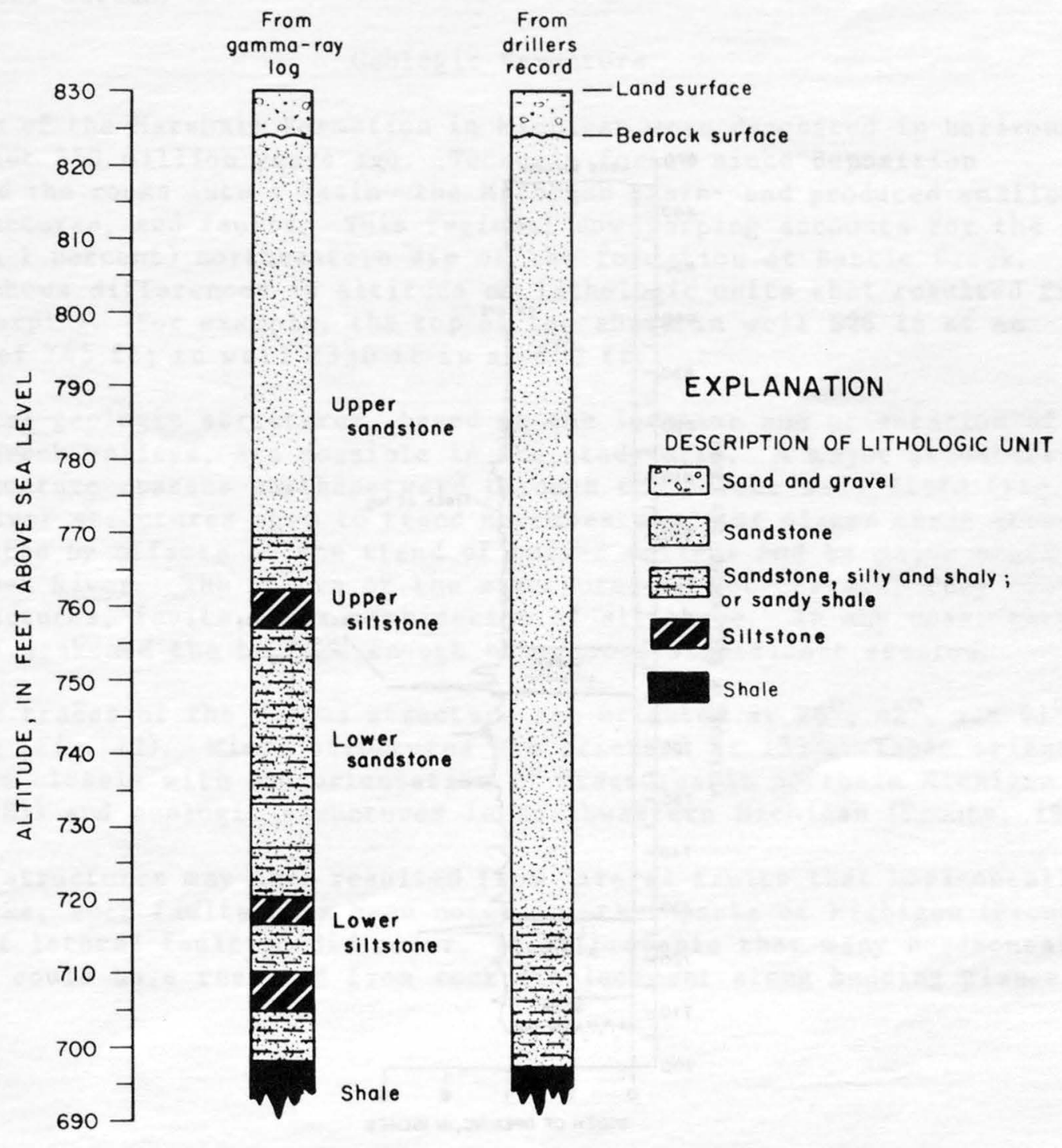

Figure 10.--Lithologic columns of Marsha11 Formation constructed from driller's record and gamma-ray $\log$ for well V17. 
Any sandstone bed in the well field that is hard or silty and shaly seems likely to contain "openings" or horizontal fractures. The location of the larger openings detected by caliper logging are shown on the geologic sections (figs. 5 to 8). An example of a caliper 108 for one well, well E29, is shown in figure 11. Some larger "openings" are present at the contacts between sandstone and siltstone; more "openings" were observed in the lower sandstone than in the upper. Also, as noted in drillers' logs, "openings" are commonly abundant in a zone directly under the upper siltstone. Video pictures of boreholes at wells V17 and V29 indicate some large circular openings. Drillers' records for some wells in the Verona well field note that there are "sufficient openings to carry away all drillings", which seems to indicate that the openings have significant lateral extension. If they are extensive, this could account, in part, for the excellent yields of the well field (as much as $14,000 \mathrm{gal} / \mathrm{min}$ with only 7 to 10 ft of drawdown).

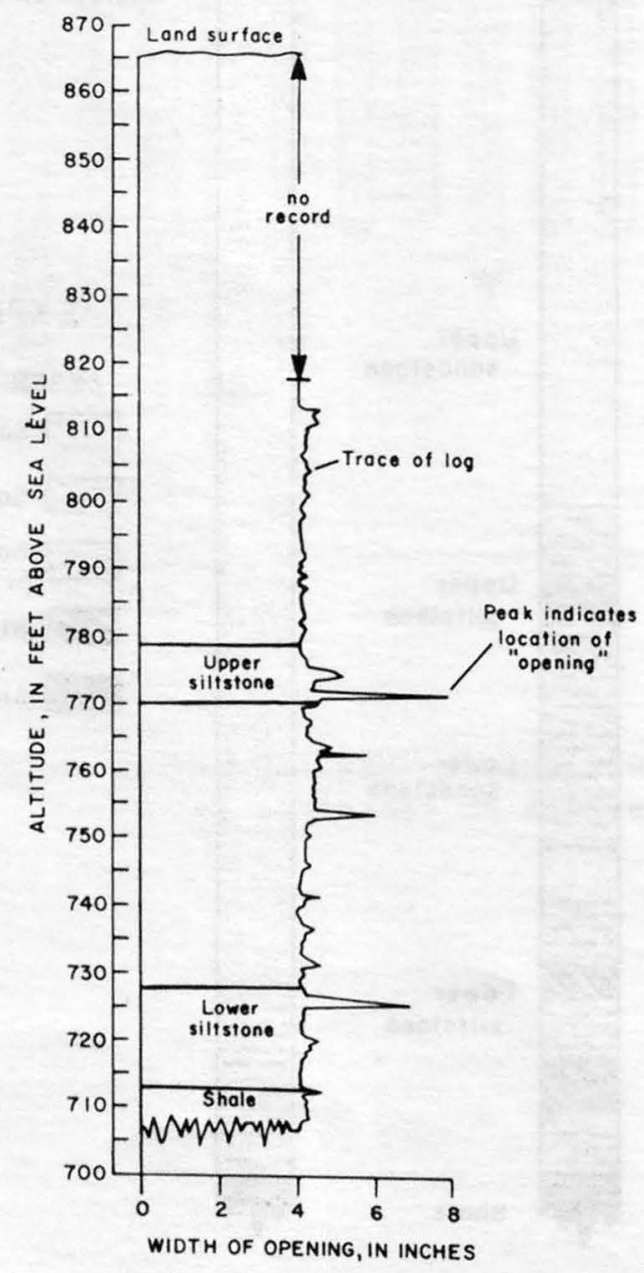

Figure 11.--Caliper log showing "openings" (probable horizontal fractures) in Marshall Formation penetrated by we11 E29. 
The bedrock surface, now buried under glacial deposits, is rolling and hilly (fig. 12). It is highest, $860 \mathrm{ft}$, in the eastern part of the study area. Northeastward trending major valleys have been carved in the surface. Evidence seems to indicate that drainage from these valleys was both to the northeast and southwest away from a high in the vicinity of Verona well field. Geologic sections $A-A^{\prime}$ and $D-D^{\prime}$ (figs. 5 and 8 ) show the relation of the valleys to the bedrock high under the well field. The valley south of the well field is as much as $75 \mathrm{ft}$ deep at Jameson Ave.

Bedrock is exposed at the northeast abutment of the dam on Battle Creek River at an altitude of $818 \mathrm{ft}$. Near well E20, bedrock may form the streambed of the river. From the dam eastward along Emmett St, bedrock forms a ridge that, under present pumping conditions, approximates the location of a major ground-water divide.

\section{Geologic Structure}

Rocks of the Marshall Formation in Michigan were deposited in horizontal layers about 350 million years ago. Tectonic forces since deposition downwarped the rocks into a basin--the Michigan Basin--and produced smaller folds, fractures, and faults. This regional downwarping accounts for the slight (less than 1 percent) northeastern dip of the formation at Battle Creek. Figure 5 shows differences in altitude of 1 ithologic units that resulted from the downwarping. For example, the top of the shale in well E26 is at an altitude of $745 \mathrm{ft}$; in we11 E33D it is at $680 \mathrm{ft}$.

Several geologic structures, based on the location and orientation of buried bedrock valleys, are possible in the study area. A major structure--the Verona structure--passes northeastward through the Verona well field (fig. 12). Several minor structures seem to trend northwestward; at places these structures are indicated by offsets in the trend of buried valleys and by major bends in Battle Creek River. The nature of the structures is not certain; they could be folds, fractures, faults, or a combination of all three. In any case, they apparently weakened the bedrock enough to promote significant erosion.

Major traces of the Verona structure are oriented at $28^{\circ}, 42^{\circ}$, and $61^{\circ}$ from true north (fig. 12). Minor structures are oriented at $133^{\circ}$. These orientations agree closely with the orientation of fractures in northern Michigan (Holst, 1983) and geologic structures in southwestern Michigan (Prouty, 1983).

Some structures may have resulted from lateral faults that horizontally offset rocks; such faults have been noted in other parts of Michigan (Prouty, 1983). If lateral faulting did occur, it is probable that many horizontal "openings" could have resulted from rock displacement along bedding planes. 

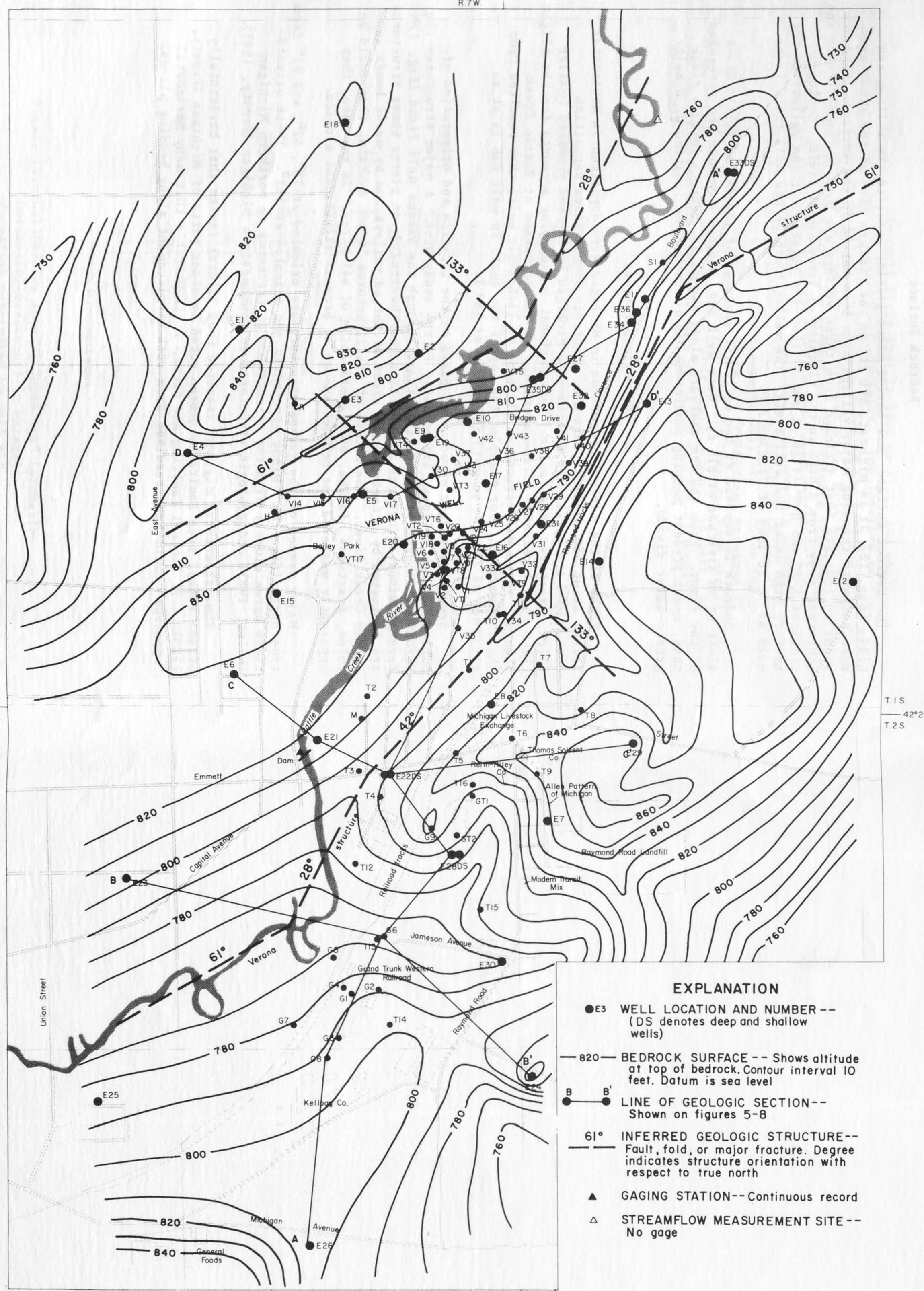

-e3 WELL LOCATION AND NUMBER (DS denotes deep and shallow wells) $-820-$ BEDROCK SURFACE - - Shows altitude
at top of bedrock. Contour interval 10

\section{B B' $B^{\prime}$ INE}

LINE OF GEOLOGIC SECTION-Shown on figures 5-8

$61^{\circ}$ INFERRED GEOLOGIC STRUCTURE-Fault, fold, or major fracture. Degree indicates structure orientation with
respect to true north

- gaging station--Continuous record

$\triangle \quad$ STREAMFLOW MEASUREMENT SITE -No gage 


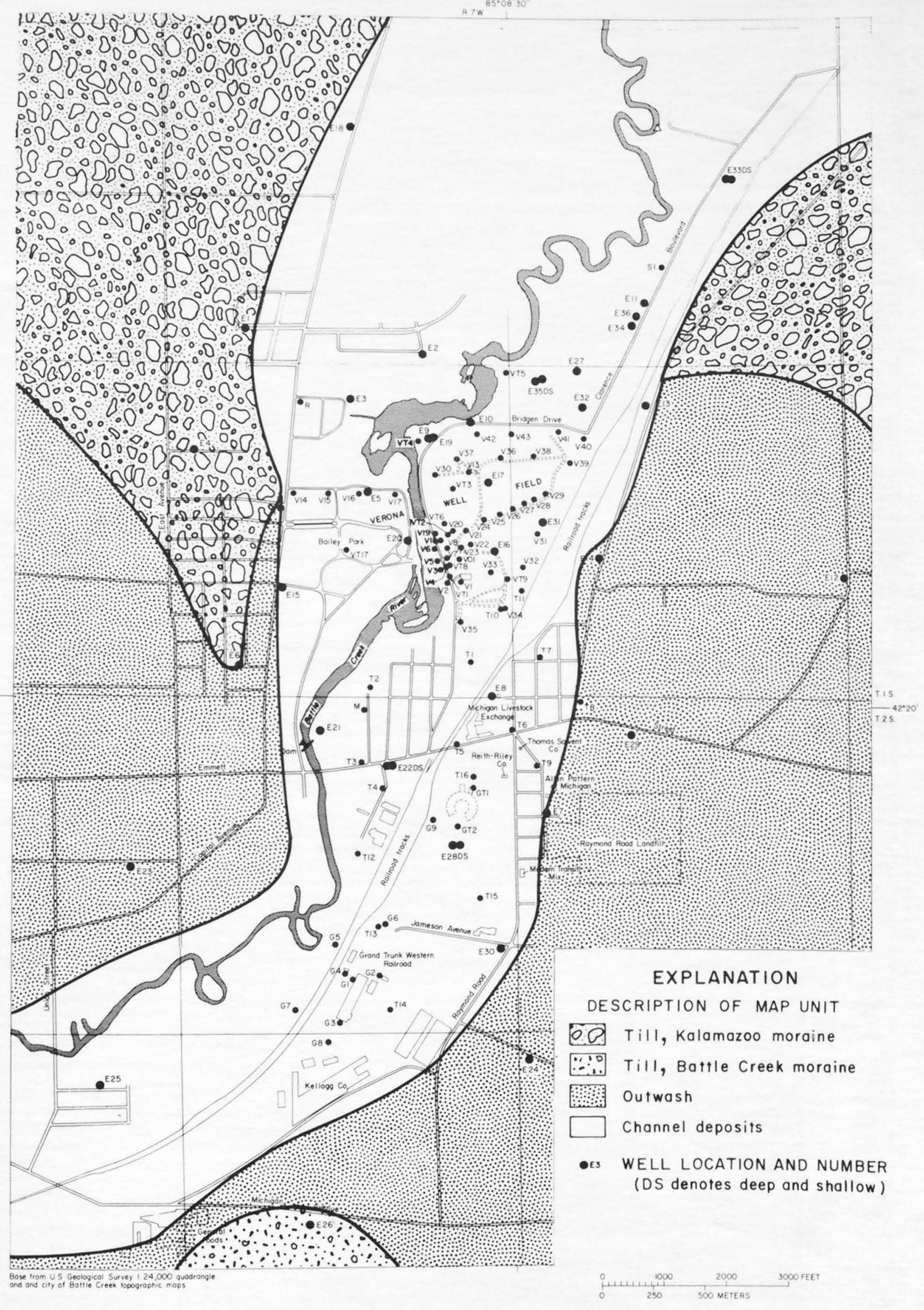

Unconsolidated materials of glacial and fluvial origin overlie the Marshall Formation in most of the study area. These materials were deposited by glaciers and glacial meltwater streams more than 12,000 years ago and by streams of nore recent age. Glacial deposits consist of till, outwash, and channel deposits.? The areal distribution of glacial deposits near Battle Creek is shown on figure 13.

Figure 13.--Areal distribution of glacial deposits.

Ti11

Till is a mixture of sand, silt, clay, gravel, and, in places, boulders. These materials, picked up, transported, and deposited by ice, formed end moraines where glacial ice maintained its outer edge for some period of time, and ground moraines where the ice sheet retreated. Ground moraines underlie most of the area except where they have been eroded by subsequent stream action. The following grain-size distribution of materials in well E26 between 55 and 57 ft below land surface is typical of till:

\begin{tabular}{lc} 
Grain size & $\begin{array}{c}\text { Percent } \\
\text { distribution } \\
\text { by weight }\end{array}$ \\
\cline { 2 - 2 } Gravel & 13.8 \\
Very coarse sand & 5.1 \\
Coarse sand & 7.2 \\
Medium sand & 27.3 \\
Fine sand & 27.3 \\
Very fine sand & 9.1 \\
Silt and clay & 10.2
\end{tabular}

The above analysis indicates that all grain sizes are well represented and

Thickness of till differs considerably throughout the area; it is thickest in morainal areas (Leverett, 1918). In the $125 \mathrm{ft}$ thick. It is $45 \mathrm{ft}$ thick at we11 $\mathrm{E} 6$ and $20 \mathrm{ft}$ thick at well $\mathrm{E} 26$. Thin till layers probably underlie most outwash deposits, but underlie channel deposits in only a few places.

Channel deposits consist of recent alluvium and glacial-stream deposits that are interconnected and have similar hydrologic characteristics. In this report, they are considered as one unit. 
Clay was found in six wells installed by the U.S. Geological Survey. No clay was found in wells installed by Ecology and Environment, Inc. (1982). Two wells in the Verona well field, wells V23 and V34, had clay or clayey material directly overlying sandstone. At Grand Trunk repair shop, glacial deposits contain a thick zone of sandy, silty clay (Environmental Data, Inc., 1982). Here the deposits are consistently more fine grained than till and may represent another origin, such as deposition in an ice-dammed lake.

Outwash

Outwash, deposited by water from melting glaciers, is mostly fine to coarse sand containing some gravel. Much of the upland area directly east and west of the well field has outwash at land surface. The following grain-size distribution of materials in well E23 between 20 and $35 \mathrm{ft}$ below land surface is typical of outwash:

Grain size

Grave1

Very coarse sand

Coarse sand

Medium sand

Fine sand

Very fine sand

Silt and clay

\author{
Percent \\ distribution, \\ by weight
}

2.4

13.9

30.9

36.4

11.9

1.7

2.8

About 85 percent of the particles are medium sand or larger.

Thickness of outwash varies depending largely on depth to the underlying bedrock. Maximum thickness is $100 \mathrm{ft}$ near well E12.

\section{Channel Deposits}

Unconsolidated materials deposited in the floodplain of Battle Creek River by glacial meltwater streams and by more recent flood waters are referred to as channel deposits. The grain size of materials in these deposits is generally larger than that in outwash. However, size distribution varies from place to place depending on location of the deposit relative to the main stream channel. The following grain-size distribution of materials in well E30 between 31 and 33 $\mathrm{ft}$ below land surface is typical of channel deposits:

\begin{tabular}{lc} 
Grain size & $\begin{array}{c}\text { Percent } \\
\text { distribution, } \\
\text { by weight }\end{array}$ \\
\cline { 2 - 2 } Gravel & 3.3 \\
Very coarse sand & 31.8 \\
Coarse sand & 31.1 \\
Medium sand & 22.0 \\
Fine sand & 7.7 \\
Very fine sand & 1.9 \\
Silt and clay & 2.2
\end{tabular}

About 90 percent of the particles are medium sand or larger. 
In many wells in channel deposits, gravel-sized coal particles were encountered at depths ranging between 20 and $30 \mathrm{ft}$. At wells E3, E11, E31, and E36, black, organic deposits are present near land surface (table 3 ).

Thickness of channel deposits varies depending largely on the topography of the underlying bedrock surface. In Bailey Park, where bedrock is near land surface, channel deposits are 6 to $8 \mathrm{ft}$ thick. One-half mile north of the park, the deposits are $5 \mathrm{ft}$ thick; bedrock was encountered during excavation for the area's sewer system. At wells E33 and E22, channel deposits are 34 and $37 \mathrm{ft}$ thick, respectively.

\section{HYDROLOGY}

Precipitation, the primary source of water in the Battle Creek area, averages 33 in. annually (National Oceanic and Atmospheric Administration, 1981). Of this, one third infiltrates the ground and percolates to the water table; the remainder flows to streams and lakes or is discharged from the area by evapotranspiration.

\section{SURFACE WATER}

Since 1935 a gaging station on Battle Creek River at the dam near Emmett St has been operated by the U.S. Geological Survey. Annual average discharge at the station is $200 \mathrm{ft}^{3} / \mathrm{s}$. Discharge between October 1981 and September 1982, ranged from 52 to $2,510 \mathrm{ft}^{3} / \mathrm{s}$; average monthly discharge during this 12-month period ranged from $398 \mathrm{ft}^{3} / \mathrm{s}$ in March to $83 \mathrm{ft}^{3} / \mathrm{s}$ in August (U.S. Geological Survey, 1982). The lowest expected discharge for a 7-day period with a probability of occurring at 10-year intervals is $33 \mathrm{ft}^{3} / \mathrm{s}$.

Discharge measurements were made at a site $2 \mathrm{mi}$ northeast of the gaging station (fig. 2) on July 9 and September 7, 1982. Thęse measurements indicaţe that the flow of Battle Creek River decreased $2.5 \mathrm{ft}^{3} / \mathrm{s}$ on July 9 and $1.0 \mathrm{ft}^{3} / \mathrm{s}$ on September 7 between the gaging station and the upstream site. (Discharge at the gaging station was $102 \mathrm{ft}^{3} / \mathrm{s}$ on July 9;56 $\mathrm{ft}^{3} / \mathrm{s}$ on September 7. This takes into account an inflow of $4.5 \mathrm{ft}^{3} / \mathrm{s}$ from purge wells $\mathrm{v} 32$ and $\left.\mathrm{v} 35.\right)$ on the basis of these measurements, and using standard U.S. Geological Survey techniques of evaluation, an average loss of $2.5 \mathrm{ft}^{3} / \mathrm{s}$ from the river was estimated. Most of the loss represents water induced from the river by municipal pumping; a minor part may have resulted from evapotranspiration. Accurate measurements could not be made nearer the well field because of slow-moving currents in that reach of the river.

\section{GROUND WATER}

\section{Recharge}

Ground water that discharges to streams and sustains perennial flow is ground-water runoff. By estimating ground-water runoff to Battle Creek River and assuming a steady-state condition (a condition wherein the amount of ground water discharged from the aquifers equals the amount of recharge they receive), it is possible to obtain a reasonable estimate of recharge. Ground-water runoff 
values, based on baseflow separations of hydrograph records during years with nearly average streamflow, are $133 \mathrm{ft}^{3} / \mathrm{s}$ at Battle Creek and $79 \mathrm{ft}^{3} / \mathrm{s}$ at earlye ( $\mathrm{mi}$. Thus, the amount of ground-water discharge to the river between Bellevue and Battle Creek is $54 \mathrm{ft}^{3} / \mathrm{s}$. To this, $2.5 \mathrm{ft}^{3} / \mathrm{s}$ wa $2.5 \mathrm{ft} / \mathrm{s}$ was a $\mathrm{s}^{3} \mathrm{~s}$ and a drainage $63 \mathrm{mi}^{2}$ resulting $56.5 \mathrm{ft}^{3} / \mathrm{s}$ and a drainage ar 12 in $/ \mathrm{yr}^{3}$ similar calculations for ground-water recharge is estimated to be 12 in/yr 3 indicate recherge to be 8 in. $/ \mathrm{yr}$

\section{Water Levels and Potentiometric Surfaces}

Water levels in wells (table 4) installed by the U.S. Geological Survey, Ecology and Environment, Inc. (1982), and Environmental Data, Inc. (1982), mostly reflect water-table conditions even though some wells are cased into the upper sandstone aquifer (fig. 3). A few wells cased into the lower sandstone aquifer reflect confined conditions. In areas of channel deposits, water moves easily between these deposits and the upper part of the upper sandstone aquifer. In areas of till and outwash underlain by till, however, resistance to vertical flow between aquifers is increased by finer grained particles of the till.

Water levels in adjacent deep and shallow wells indicate differences in direction of vertical flow. For example, at wells E33D and E33S which are $5 \mathrm{ft}$ apart, water levels in well E33D were as much as $0.5 \mathrm{ft}$ above levels in well E33S. At this location, ground water in the bedrock is moving slowly upward. Levels at wells E22 were 0.38 to $0.65 \mathrm{ft}$ lower in the deep well than in the shallow; 1 evels at wells E28 were 1.09 to $1.73 \mathrm{ft}$ lower in the deep than in the shallow. At these sites, ground water in the shallow aquifer is moving slowly downward. At some sites, such as at wells G1, the level in one well at a given time may be higher or lower than in the other depending on amount of recharge.

\footnotetext{
${ }^{3}$ For Kalamazoo River, south of the study area, recharge is estimated to be
} $11 \mathrm{in./yr}$. 
Water levels listed in table 4 and shown by potentiometric surfaces in Date of measurement

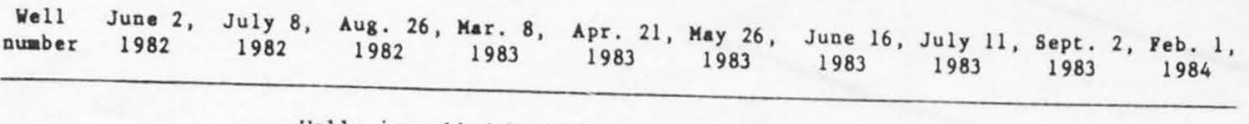
Hel1. inatal1ed by zcology and Bnvironment, Inc.

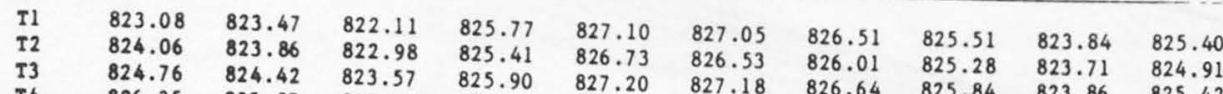

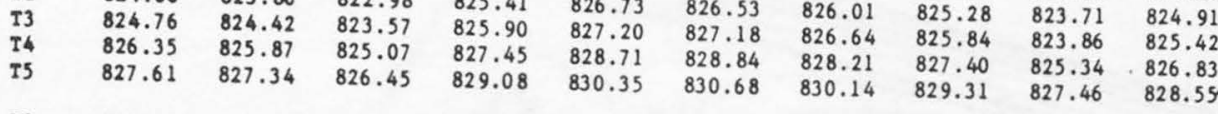

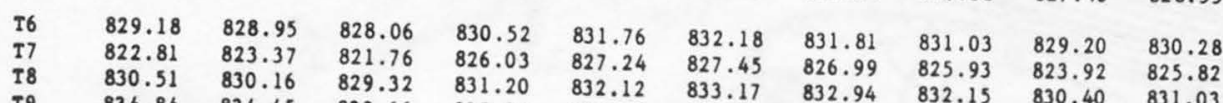

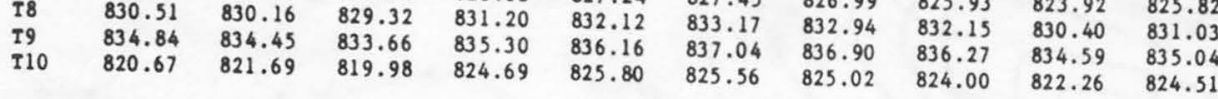

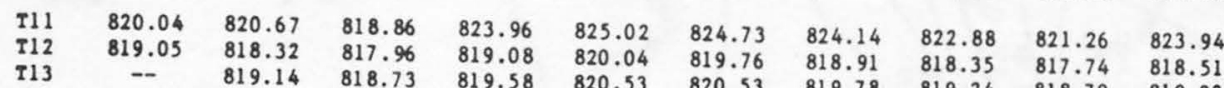

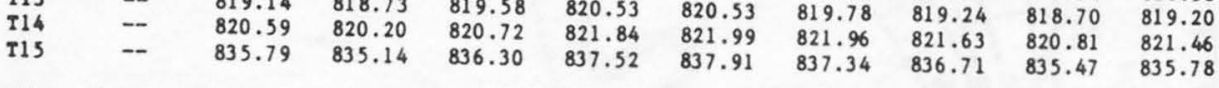
$\begin{array}{lllllllllll}\mathrm{r16} & 829.05 & 828.61 & 827.79 & 830.21 & 831.36 & 830.94 & 831.21 & 830.41 & 828.57 & 829.63\end{array}$ Wells installed by gavironaenta1 Data, Inc.

\begin{tabular}{|c|c|c|c|c|c|c|c|c|c|c|}
\hline $\begin{array}{l}{ }_{G 1} \\
G 1\end{array}$ & $=$ & $=$ & $\begin{array}{l}818.07 \\
817.83\end{array}$ & $\begin{array}{l}818.64 \\
---64\end{array}$ & $\begin{array}{l}820.06 \\
--.\end{array}$ & $\begin{array}{l}819.65 \\
---65\end{array}$ & $\begin{array}{l}819.26 \\
---26\end{array}$ & 817.64 & $\begin{array}{l}818.27 \\
818\end{array}$ & \\
\hline $\begin{array}{l}{ }_{6}^{618} \\
\text { Glc }\end{array}$ & $\overline{-}$ & $\overline{-}$ & $\begin{array}{l}818.06 \\
818.18\end{array}$ & $\begin{array}{l}818.60 \\
818.86\end{array}$ & $\begin{array}{l}820.03 \\
819.84\end{array}$ & $\begin{array}{l}819.64 \\
820.11\end{array}$ & $\begin{array}{l}819.23 \\
820.18\end{array}$ & $\begin{array}{l}819.90 \\
820.14\end{array}$ & $\begin{array}{l}818.22 \\
818.68\end{array}$ & $\begin{array}{l}818.68 \\
818.68 \\
819.80\end{array}$ \\
\hline 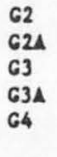 & $\begin{array}{l}z- \\
-z \\
--\end{array}$ & $\begin{array}{l}-- \\
z- \\
--\end{array}$ & $\begin{array}{l}818.67 \\
818.66 \\
817.88 \\
817.86 \\
817.80\end{array}$ & $\begin{array}{l}819.10 \\
819.10 \\
818.42 \\
818.44 \\
818.49\end{array}$ & $\begin{array}{l}820.60 \\
820.59 \\
819.91 \\
819.99 \\
819.99\end{array}$ & $\begin{array}{l}820.25 \\
820.23 \\
819.54 \\
819.53 \\
819.36\end{array}$ & $\begin{array}{l}819.86 \\
819.85 \\
819.919 \\
819.18 \\
818.92\end{array}$ & $\begin{array}{l}819.35 \\
819.35 \\
818.70 \\
818.70 \\
818.44\end{array}$ & $\begin{array}{l}818.83 \\
818.91 \\
818.09 \\
818.07 \\
817.91\end{array}$ & \\
\hline 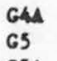 & $\overline{-}$ & $\overline{--}$ & $\begin{array}{l}817.77 \\
---77\end{array}$ & 818.39 & 819.76 & $\begin{array}{l}819.36 \\
---\end{array}$ & $\begin{array}{l}818.88 \\
--8\end{array}$ & 818.44 & $\begin{array}{l}817.87 \\
811.37\end{array}$ & $\begin{array}{l}818.40 \\
817.87\end{array}$ \\
\hline & $=$ & -- & $=$ & $=$ & -- & $=$ & -- & $=$ & $\begin{aligned} 818 \\
818.31\end{aligned}$ & $\begin{array}{l}817.87 \\
819 \\
824.98\end{array}$ \\
\hline & - & -- & -- & -- & -- & - & -- & - & 816.68 & $\begin{array}{l}824.98 \\
817.64\end{array}$ \\
\hline $\begin{array}{c}674 \\
68\end{array}$ & $=$ & - & -- & -- & -- & $\overline{--}$ & $=$ & $\overline{-z}$ & $\begin{array}{l}816.02 \\
817.91\end{array}$ & $\begin{array}{l}817.59 \\
818.82\end{array}$ \\
\hline & - & -- & -- & $=$ & -- & $=$ & $=$ & - & 818.37 & $\begin{array}{l}819.76 \\
828.68\end{array}$ \\
\hline & -- & - & -- & -- & -- & -- & -- & - & 827.55 & 828.70 \\
\hline
\end{tabular}

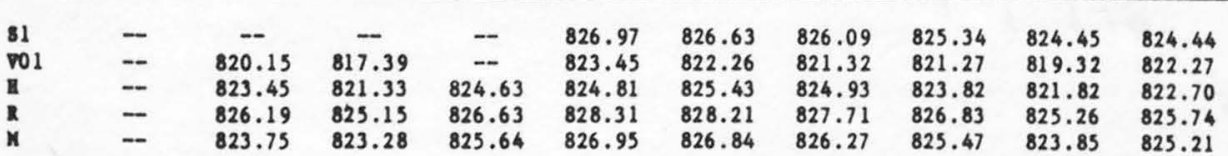

Area of map is larger than that of study area in figure 2 in order to include modeled area discussed in section titled "Ground-water flow simulations".

Based on water quality data provided by the Michigan Department of Public Health, a significant source of contaminants is an area near the Emmett StRaymond Rd intersection. 


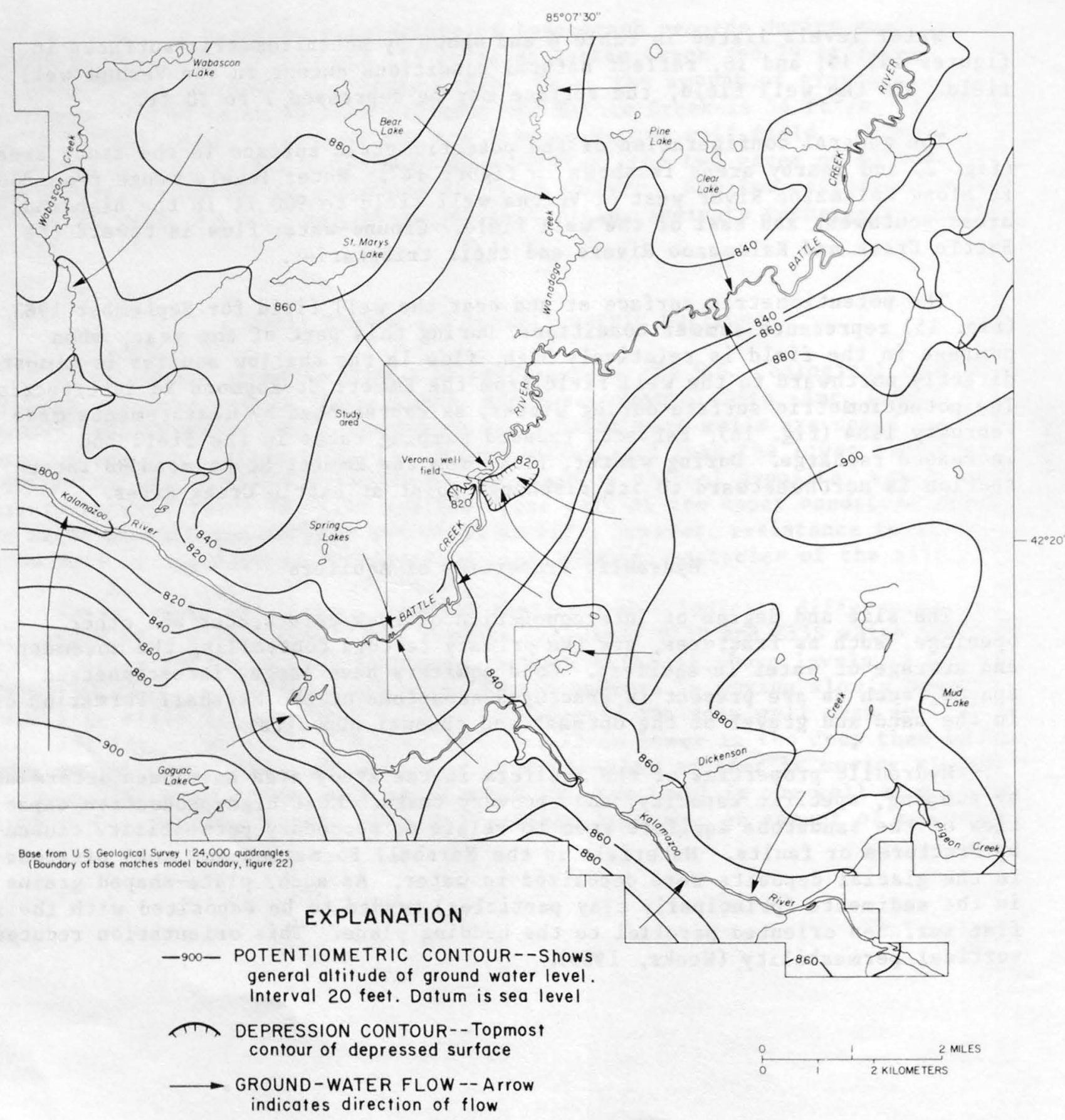

Figure 14.--Generalized average potentiometric surface of study area and area included in model (for model area see section titled "Ground-water flow mode1"). 


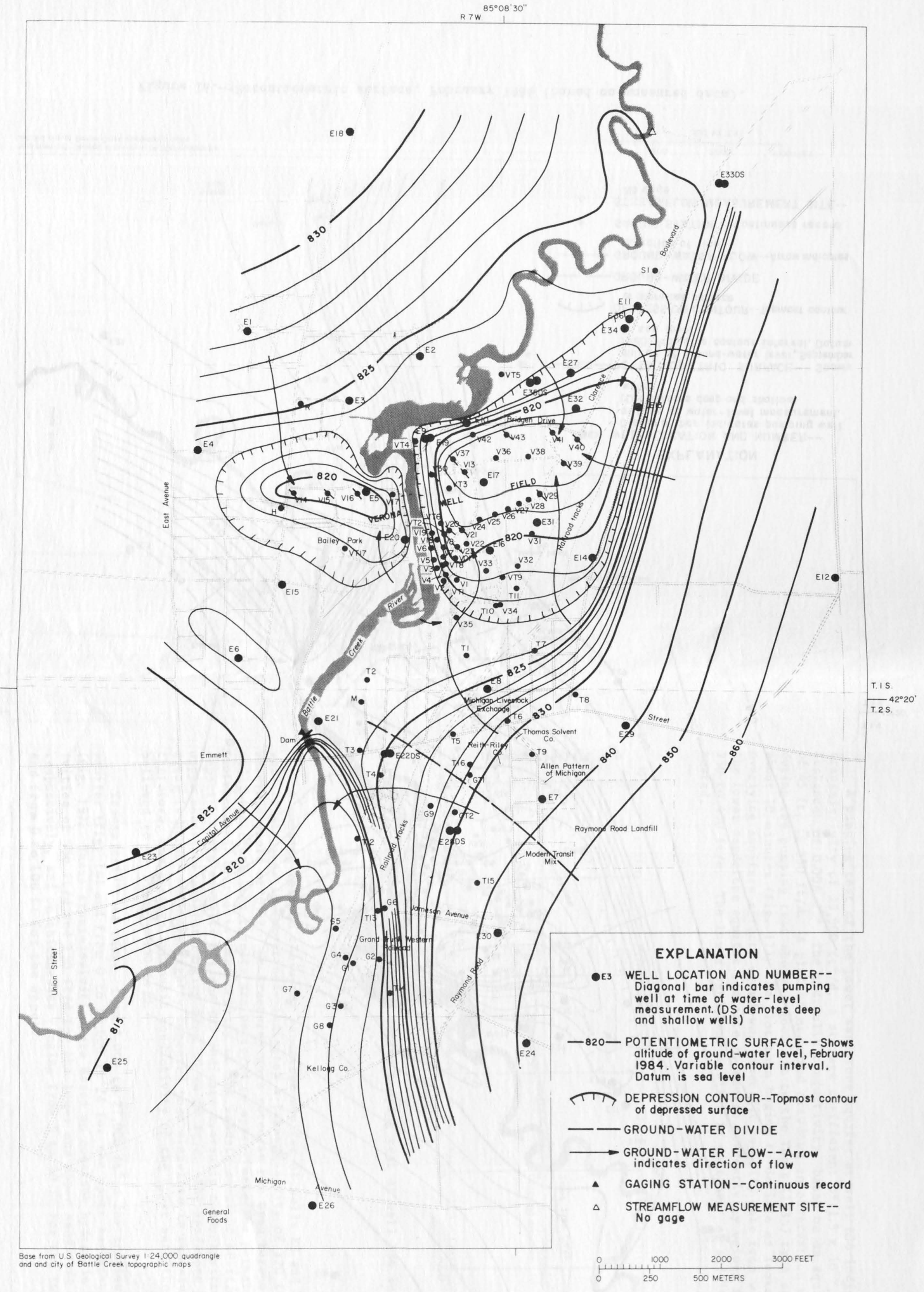

Figure 15.--Potentiometric surface, September 1983 (based on measured data). 


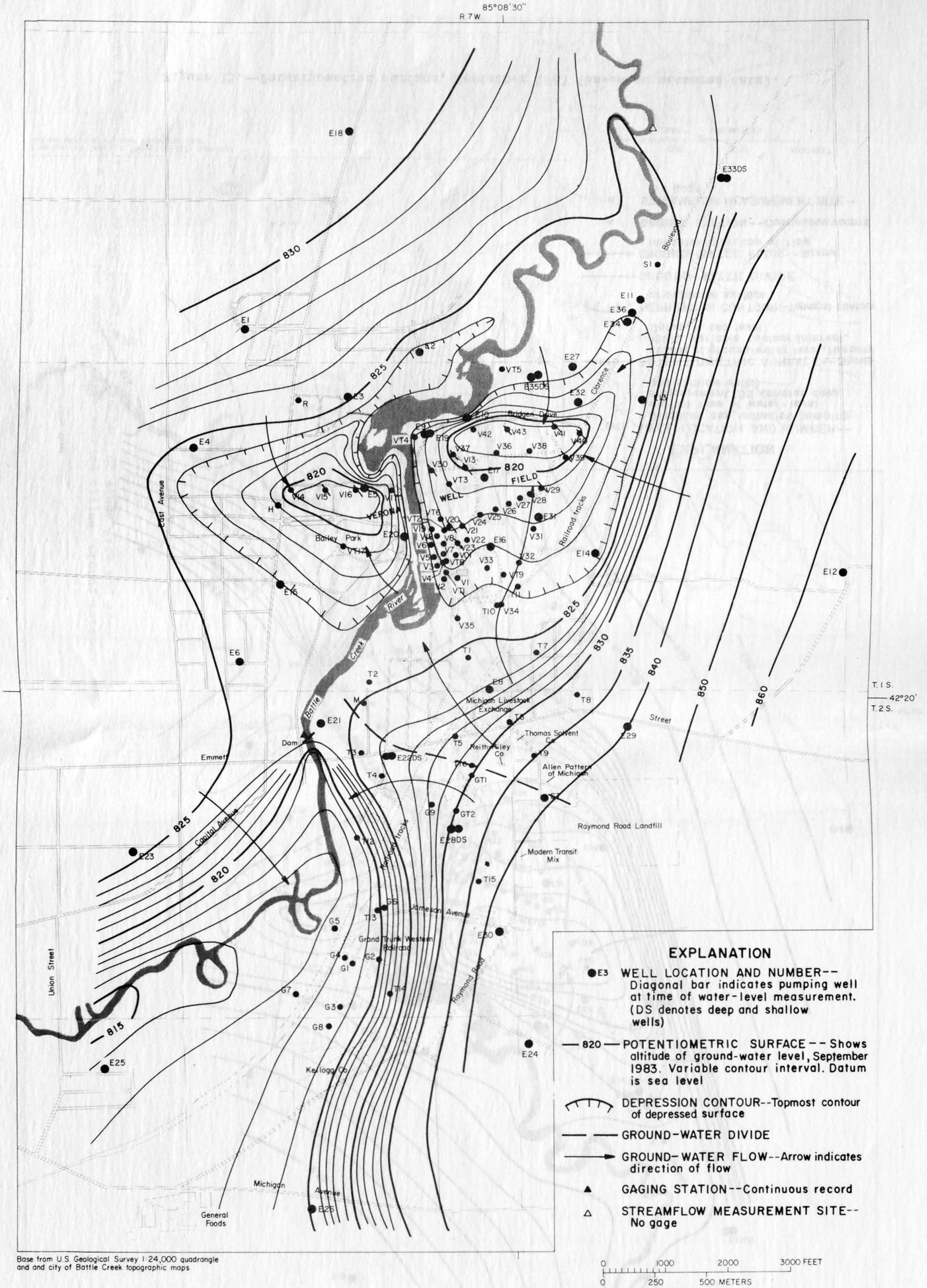

Figure 16.--Potentiometric surface, February 1984 (based on measured data). 
A pumping test of the lower sandstone aquifer at well E36 indicates a transmissivity of $25,000 \mathrm{ft}^{2} / \mathrm{d}$, a storage coefficient of $1.5 \times 10^{-5}$, and a leakance of $0.004 \mathrm{~d}^{-1}$. The hydraulic conductivity, based on an aquifer thickness of $45 \mathrm{ft}$, is $550 \mathrm{ft} / \mathrm{d}$. A plot of measured drawdown in observation we11 E34 during the pumping test shows a good fit to the Theis (1935) type curve for about 10 minutes ( $\mathrm{fig}$. 17); the plot then begins to deviate as leakage from the overlying aquifers affects drawdown. Specific capacity data from wells open in the lower sandstone aquifer indicate hydraulic conductivity values ranging from 250 to $450 \mathrm{ft} / \mathrm{d}$. The lower sandstone aquifer is confined at all locations tested.

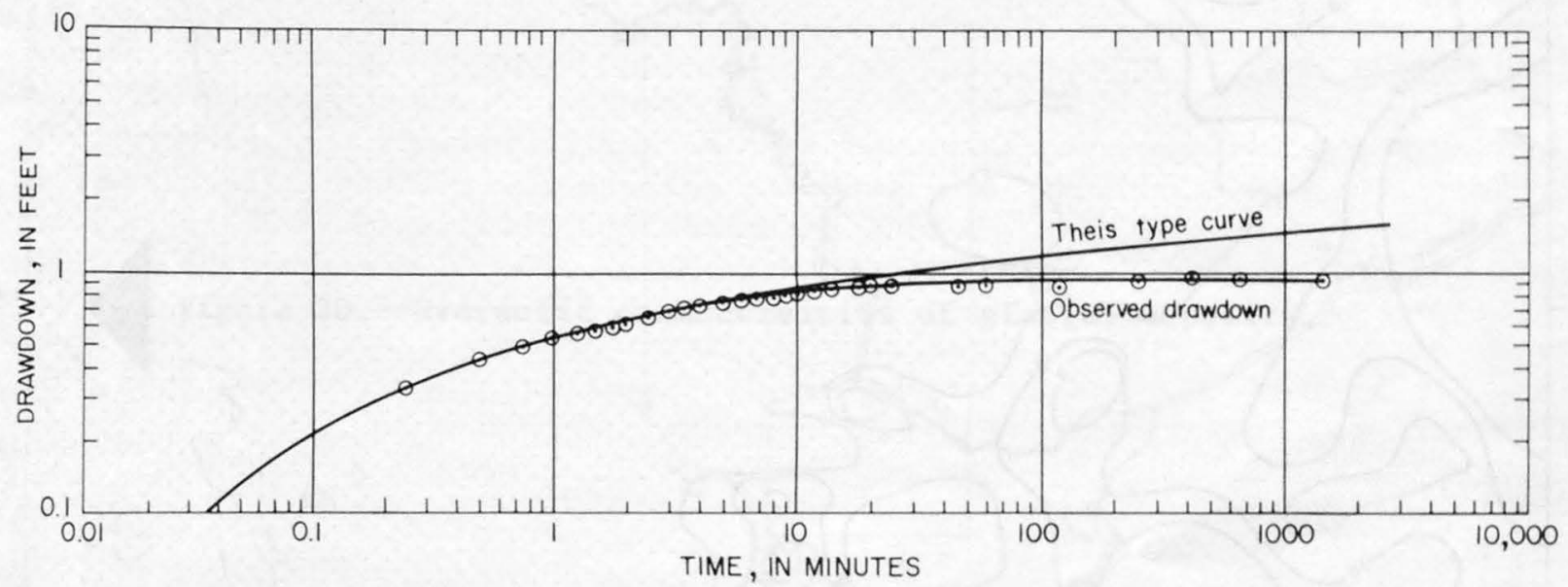

Figure 17.--Drawdown in well E34 during pumping test at well E36 and Theis type curve.

A pumping test on the upper sandstone aquifer at wells E9 and El $19--a$ site were the aquifer is unconfined--indicates a transmissivity of $320 \mathrm{ft} / \mathrm{d}$ and a specific yield of 0.02 . No fractures were noted in the open borehole of the well; therefore, the results are believed to approximate the primary (unfractured) hydraulic conductivity of the sandstone--about $10 \mathrm{ft} / \mathrm{d}$. Specific capacity tests at wells E21 and E32 indicate hydraulic conductivities for the upper sandstone aquifer ranging from 40 to $80 \mathrm{ft} / \mathrm{d}$. The sandstone at these sites is harder and more tightly cemented than elsewhere in the study area; therefore, the average hydraulic conductivity of the upper sandstone aquifer is believed to be higher--150 ft/d.

Transmissivities range from 3,000 to $27,000 \mathrm{ft}^{2} / \mathrm{d}$ for the lower sandstone aquifer ( $\mathrm{fig} .18$ ) and from 0 to $15,000 \mathrm{ft}^{2} / \mathrm{d}$ for the upper sandstone aquifer (fig. 19). These transmissivities are based on constant hydraulic conductivities of $550 \mathrm{ft} / \mathrm{d}$ and $150 \mathrm{ft} / \mathrm{d}$ for the lower and upper sandstone aquifers, respectively, and on thicknesses ranging from 5 to $50 \mathrm{ft}$ for the lower aquifer and from 0 to $100 \mathrm{ft}$ for the upper. 


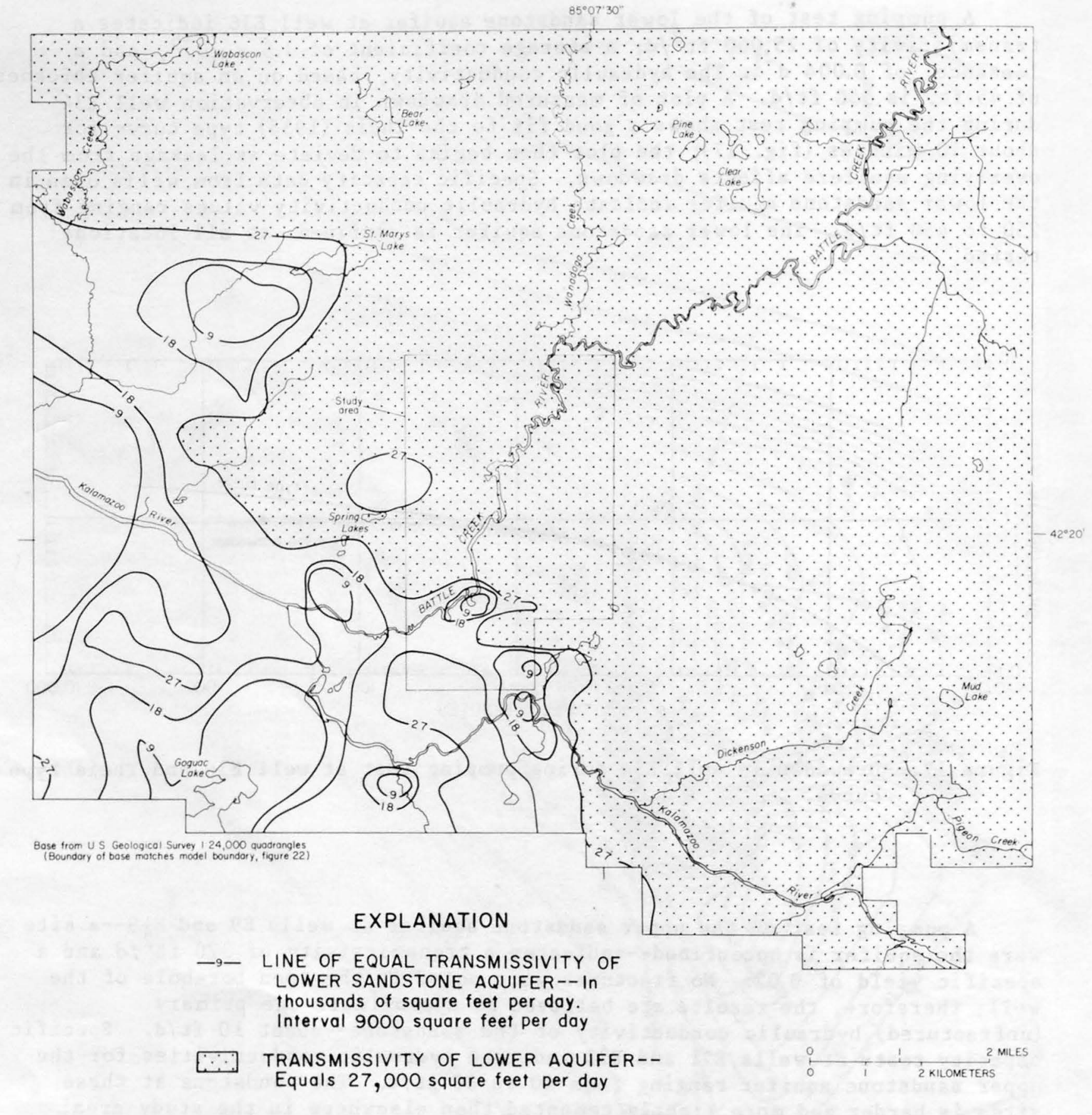

Figure 18.--Transmissivity of lower sandstone aquifer.

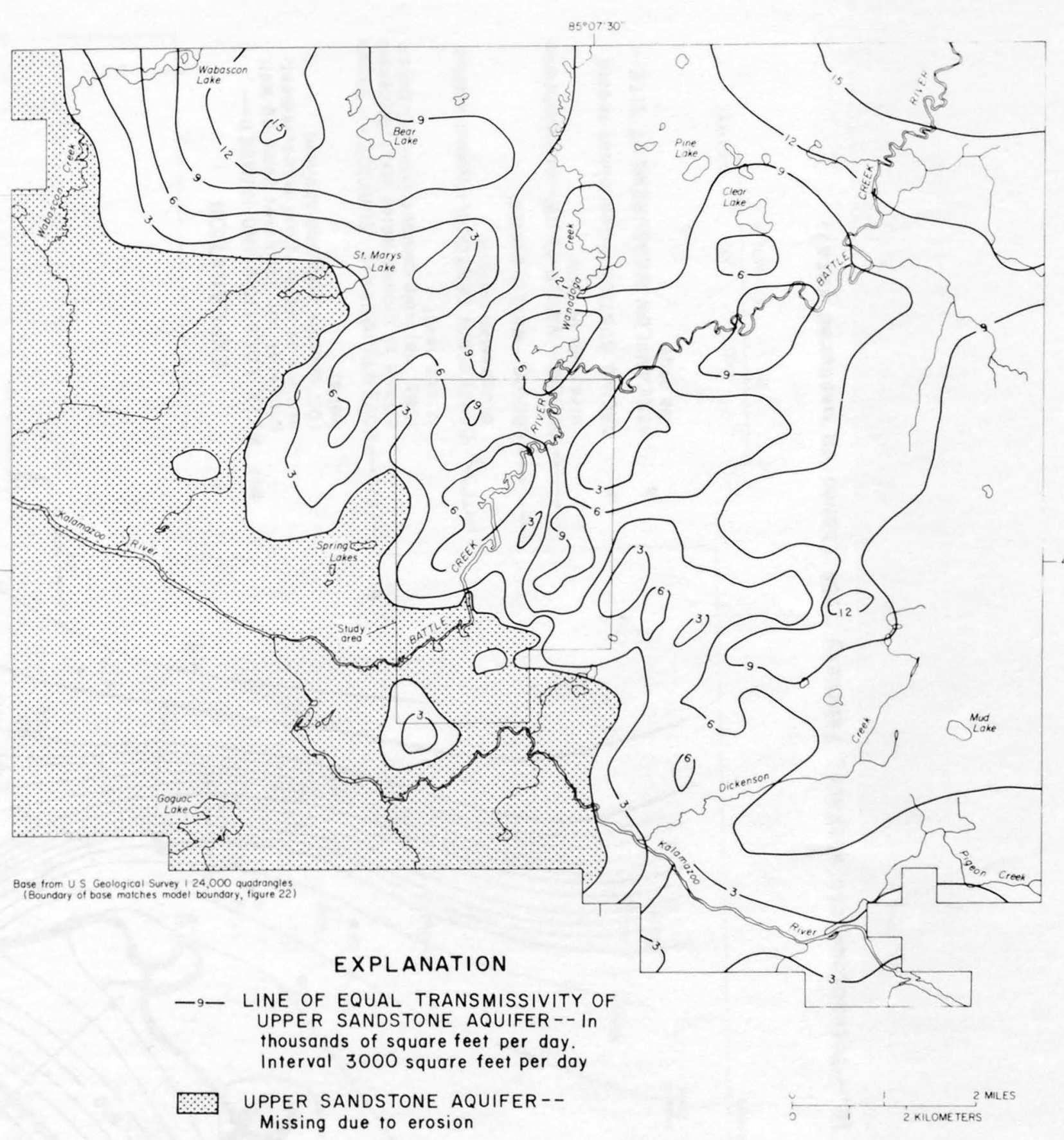

Figure 19.--Transmissivity of upper sandstone aquifer. 


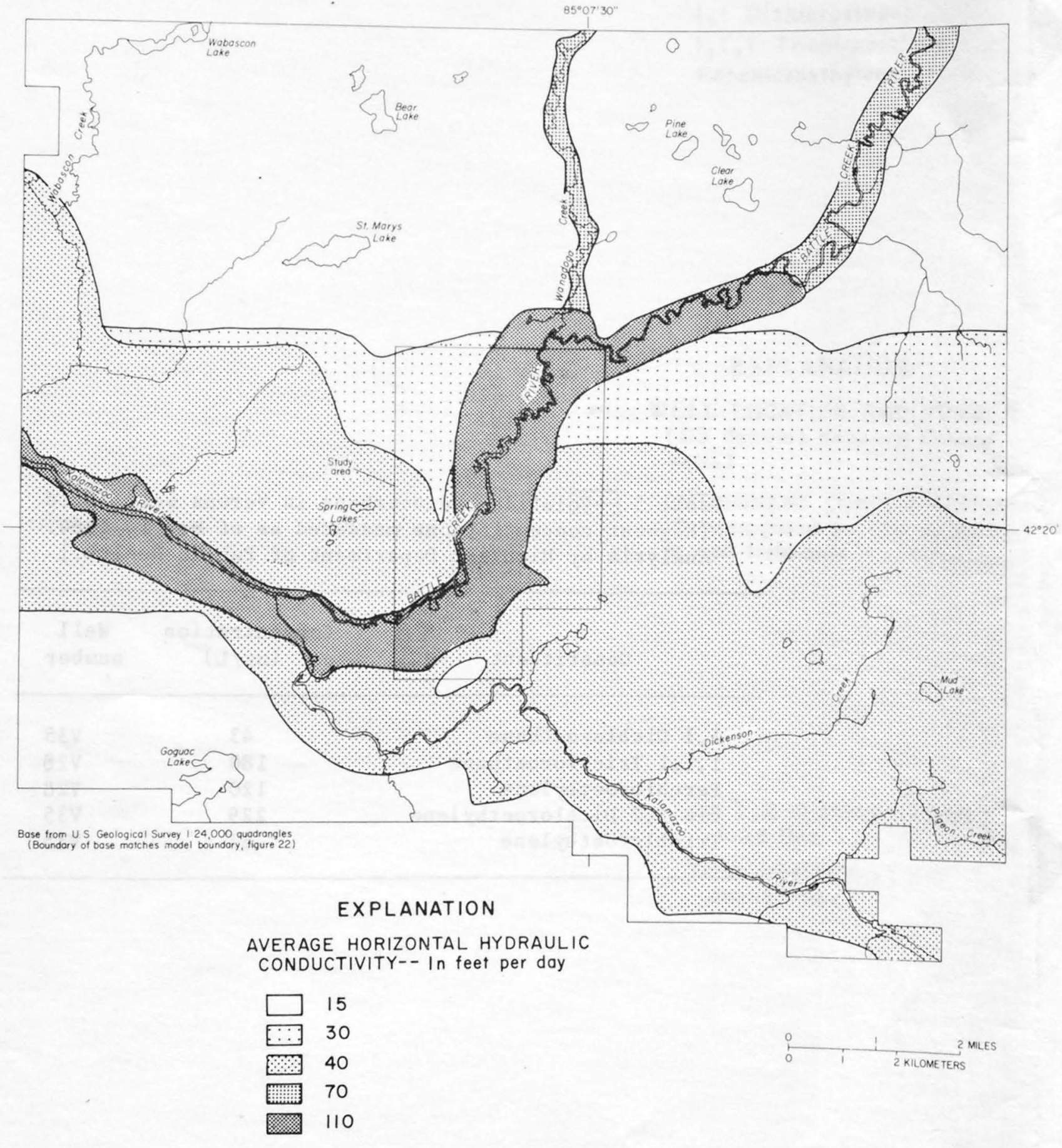

The hydraulic properties of the glacial deposits differ with the type of deposit. Based on grain-size analysis and similarity with other deposits in Michigan, horizontal hydraulic conductivity is estimated to be $110 \mathrm{ft} / \mathrm{d}$ for channel deposits, $70 \mathrm{ft} / \mathrm{d}$ for outwash, and $15 \mathrm{ft} / \mathrm{d}$ for till ( $\mathrm{fig} 20$ ). In a transition zone near the edge of the Kalamazoo moraine, hydraulic conductivity of interlayered till and outwash is estimated to be $30 \mathrm{ft} / \mathrm{d}$. The specific yield of outwash and channel deposits is estimated to be 0.15 ; the specific yield of till is not known. However, because till in the study area is coarse textured, its ability to store water may not be significantly less than that of other glacial deposits.

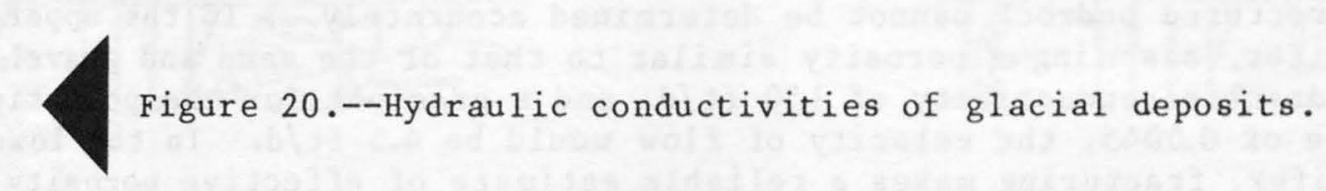


Velocity of ground-water flow depends on the gradient of the potentiometric surface and on the hydraulic conductivity and effective porosity ${ }^{6}$ of the aquifer. Along the margin of the Battle Creek River floodplain, the gradient of the potentiometric surface in the sand and gravel aquifer is steep (figs. 15 and potentiometric surface in the sand and gravel aquifer is steep (figs. 15 and 16), and ground water flow is comparatively rapid (as much as fe/d); within the floodplain the gradient is less and flow is slower. An effective porosity of 0.15 , an average hyraulic conductivity of $100 \mathrm{ft} / \mathrm{d}$, and water-ievel data were used to calculate flow velocity in the sand and gravel aquifer. The average velocity in September 1983, for example, between the Emmett St-Raymond Rd intersection (see foothote and pumping wells v38-v43 in the well field, was 2 $\mathrm{ft} / \mathrm{d}$. The highest velocity, $4 \mathrm{ft} / \mathrm{d}$, was at the intersection; the lowest, $\mathrm{ft} / \mathrm{d}$, was near the south edge of the field. For February 1984, velocities in the sand and gravel aquifer were 4 ft/d at the intersection, 1.5 river, and $1 \mathrm{ft} / \mathrm{d}$ in the southern part of the well field.

Ground-water-flow velocities can also be calculated for the sandstone aquifers; however, they are less accurate because a value for effective porosity of the fractured bedrock cannot be determined accurately. In the uppe sandstone aquifer, assuming a porosity similar to that of the sand and gravel aquifer, a hydraulic conductivity of $150 \mathrm{ft} / \mathrm{d}$, and a gradient for the potentiometric surface of 0.0045 , the velocity of flow would be $4.5 \mathrm{ft} / \mathrm{d}$. In the lower sandstone aquifer, fracturing makes a reliable estimate of effective porosity difficult, and thus, precludes calculations of flow velocity.

On the basis of the above calculations, movement of contaminants in the well field may be at rates varying from 1 to $4 \mathrm{ft} / \mathrm{d}$.

\section{Quality of Water}

\section{Verona Well Field}

Investigation of the quality of water in the well field was not part of this study. However, the Michigan Department of Public Health has analysed water from municipal wells for volatile hydrocarbons since the latter part of 1981. Using their data, distribution of hydrocarbons in the well field in 1982 and during the latter part of 1983 and early part of 1984 is shown in figure 21 . Highest concentrations measured as of May 1, 1984, were as shown in table 5 .

${ }^{6}$ Numerical values of specific yield, which are approximately equal to values of effective porosity, have been used in the calculations.

Table 5.--Volatile hydrocarbons in Verona well field [Highest concentrations measured as of May 1, 1984. Analysis by Michigan Department of Public Health.]

\begin{tabular}{lcc}
\hline \multicolumn{1}{c}{ Constituent } & $\begin{array}{c}\text { Concentration } \\
(\mu \mathrm{g} / \mathrm{L})\end{array}$ & $\begin{array}{c}\text { We11 } \\
\text { number }\end{array}$ \\
\hline 1,1 Dichloroethane & 43 & V35 \\
1,1,1 Trichloroethane & 180 & V28 \\
Perchloroethylene & 120 & V28 \\
cis 1,2 Dichloroethy lene & 229 & V35 \\
Trichloroethylene & 67 & V35
\end{tabular}


I,I Dichloroethane

I,1,1 Trichloroethane

Perchloroethylene

\section{EXPLANATION}

-3 WELL LOCATION AND NUMBER ( $D S$ denotes deep and shallow wells )

DONTAMINENT CONCENTRATION-IO micrograms per liter or more. In well field only

cis 1,2 Dichloroethylene; solid line Trichloroethylene; dashed line

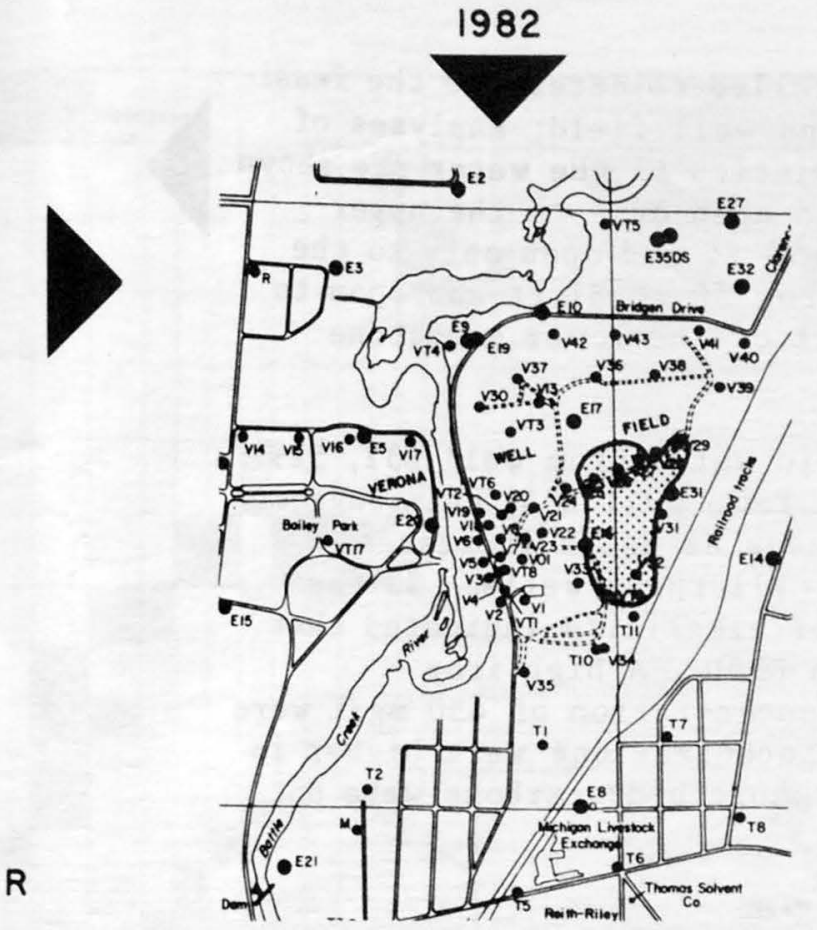

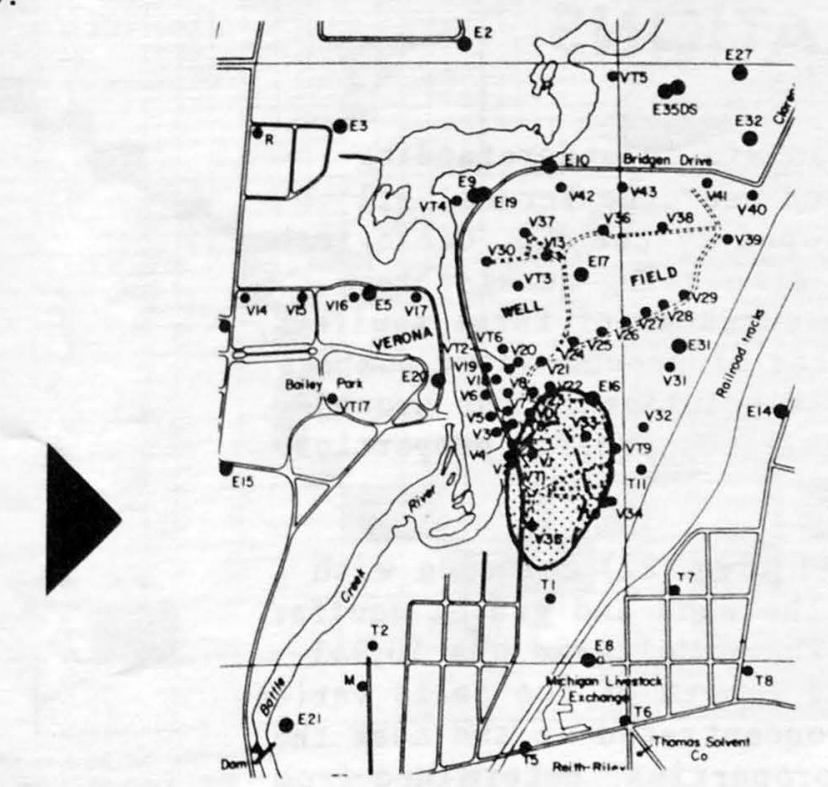

$1983-1984$
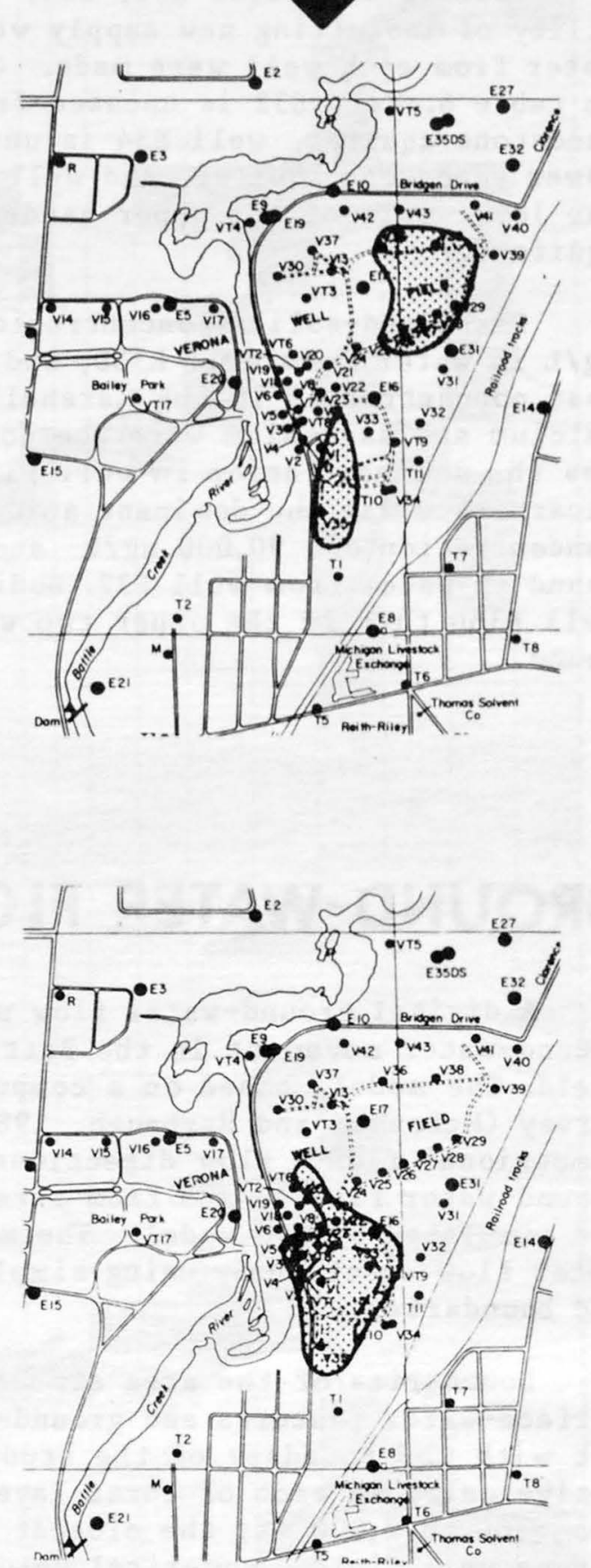

Figure 21.--Distribution of volatile hydrocarbons in Verona well field in latter part of 1981 and in latter part of 1983--early part of 1984 (based on data from Michigan Department of Public Health). 


\section{North of Well Field}

Observation wells E32, E34, and E35D were installed to determine the feasibility of installing new supply wells north of Verona well field; analyses of water from each well were made. Chemical characteristics of the water are shown in table 6. Well E32 is uncased from 36 to $60 \mathrm{ft}$ and open only to the upper sandstone aquifer, well E34 is uncased from 79 to $155 \mathrm{ft}$ and open only to the lower sandstone aquifer, and well E35D is uncased from 50 to $81 \mathrm{ft}$ and open to the lower part of the upper sandstone and upper part of the lower sandstone aquifers.

Dissolved-solids concentrations were $671 \mathrm{mg} / \mathrm{L}$ in water from well E32, 529 $\mathrm{mg} / \mathrm{L}$ in water from well E35D, and $283 \mathrm{mg} / \mathrm{L}$ in water from well E34; this suggest that concentration in the Marshall Formation decreases as depth increases. Calcium and magnesium were the dominant cations in all three wells. Sulfate was the dominant anion in well E32; measurements of alkalinity indicated that bicarbonate was the dominant anion in wells E34 and E35D. A high iron

concentration of $90,000 \mu \mathrm{g} / \mathrm{L}$ and a high sulfate concentration of $430 \mathrm{mg} / \mathrm{L}$ were found in water from well E32. Sodium and chloride concentrations were higher in than in the other two wells, Volatile organic hydrocarbons were not found.

\section{GROUND-WATER FLOW SIMULATIONS}

A digital ground-water flow model was used as an aid in understanding ground-water movement in the Battle Creek area at and near the Verona well rield. The model, based on a computer program developed by the U.S. Geological Survey (McDonald and Harbaugh, 1983), is capable of simulating quasi-threedimensional flow. Flow directions, potentiometric surfaces of three aquifers, ground-water flow to and from streams, and the effects of ground-water pumpage are simulated by the model. The model approximates a solution to the groundwater flow equation by using simplifying assumptions about aquifer properties and boundaries.

Boundaries of the area simulated with the model (fig. 22) coincide with surface-water features and ground-water divides in the sand and gravel aquifer, not with the boundary of the study area (fig. 2). The model grid has 10,943 active cells in each of three layers. The width and length of the cells varie from 100 to $2,000 \mathrm{ft}$; the closest grid spacing is concentrated at and near the Verona well field. Numerical values of hydrologic properties, determined from field data, are assigned to each cell; the properties of each cell are assumed to be homogeneous. These values define the top and bottom of each of the three aquifers, the location of streams and lakes and the hydraulic properties of their botton material, the hydraulic conductivity of the aquifers, recharge the aquifers, and locations and pumping rates of wells.
Table 6.--Chemical and physical characteristics of water from observation wells north of Verona well field

\begin{tabular}{|c|c|c|c|}
\hline Conatituent or property & $\begin{array}{l}\text { We11 } \\
\text { E32 }\end{array}$ & $\begin{array}{l}\text { We11 } \\
\text { E34 }\end{array}$ & $\begin{array}{l}\text { We } 11 \\
\text { E3SD }\end{array}$ \\
\hline $\begin{array}{l}\text { Temperature (deg. C) } \\
\text { Turbidity (ntu) }\end{array}$ & 11.0 & 11.0 & 11.0 \\
\hline $\begin{array}{l}\text { Turbidity (ntu) } \\
\text { oolor (platinum cobalt units) }\end{array}$ & $\begin{array}{c}100 \\
15\end{array}$ & ${ }_{10}^{1.1}$ & $\begin{array}{l}3.0 \\
2.0\end{array}$ \\
\hline $\begin{array}{l}\text { Specific conductance (micromios) } \\
\text { pH (unite) }\end{array}$ & $\begin{array}{l}13 \\
841 \\
6,6\end{array}$ & $\begin{array}{r}10 \\
470\end{array}$ & $\begin{aligned} 2.0 \\
834 \\
7.0\end{aligned}$ \\
\hline 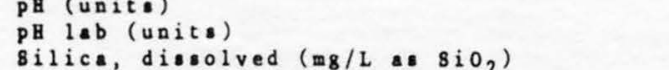 & $\begin{array}{l}6.6 \\
4.7\end{array}$ & 7. & $\begin{array}{r}7.0 \\
7.1\end{array}$ \\
\hline 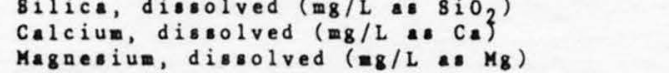 & $\begin{array}{l}45 \\
59\end{array}$ & $\begin{array}{l}14 \\
68\end{array}$ & $\begin{array}{r}13 \\
100\end{array}$ \\
\hline 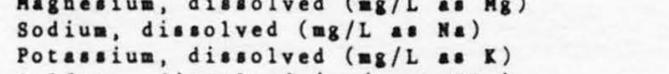 & $\begin{array}{c}25 \\
3.2 \\
2.1\end{array}$ & $\begin{array}{r}21 \\
6 .\end{array}$ & $\begin{array}{l}27 \\
24\end{array}$ \\
\hline 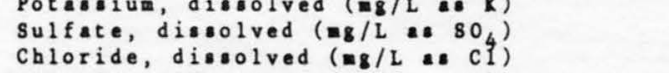 & $\begin{array}{rl}230 & 2.1 \\
2.2 & -1\end{array}$ & 30 & $\begin{array}{l}1.1 \\
57 \\
1.30\end{array}$ \\
\hline 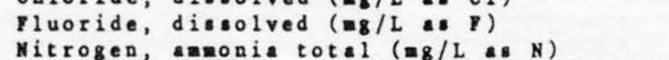 & 1.60 & & $\therefore$ \\
\hline 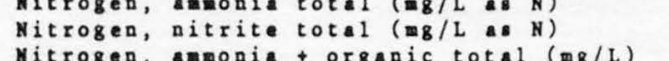 & $<.01$ & $\therefore .01$ & \\
\hline 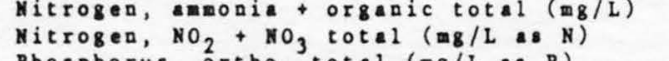 & $\therefore 10$ & $<10$ & $\begin{aligned}<.36 \\
<16\end{aligned}$ \\
\hline 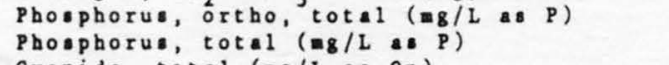 & .06 & $\begin{array}{c}.01 \\
.02\end{array}$ & \\
\hline 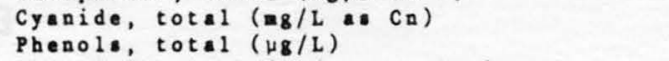 & --2 & ${ }_{2}^{<.01}$ & \\
\hline 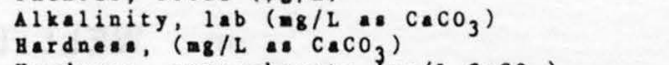 & $250^{1}$ & $\begin{array}{l}141 \\
260\end{array}$ & $\begin{array}{l}195 \\
360\end{array}$ \\
\hline 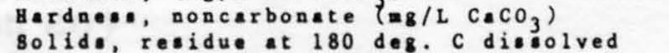 & $6 \overline{7}$ & $\begin{array}{l}116 \\
283\end{array}$ & $\begin{array}{l}166 \\
529\end{array}$ \\
\hline 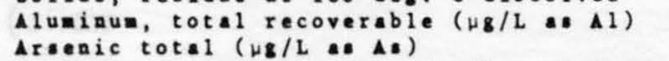 & ${ }_{2}^{10}$ & $\begin{array}{r}50 \\
1\end{array}$ & $\begin{array}{r}30 \\
2\end{array}$ \\
\hline 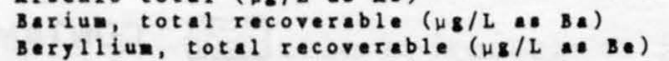 & $\begin{aligned}<100 \\
<10\end{aligned}$ & $\begin{array}{l}100 \\
<10\end{array}$ & $\begin{aligned} 300 \\
<10\end{aligned}$ \\
\hline 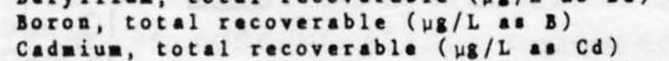 & $\underset{2}{20}$ & $<20$ & $<20$ \\
\hline 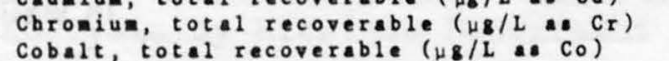 & $\begin{array}{l}10 \\
33\end{array}$ & $\begin{array}{r}10 \\
1\end{array}$ & $\begin{array}{r}10 \\
2\end{array}$ \\
\hline 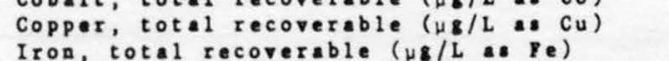 & 90,000 & $420^{2}$ & 1,000 \\
\hline 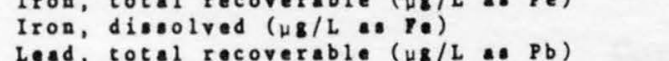 & & 420 & $\begin{array}{r}830 \\
830\end{array}$ \\
\hline 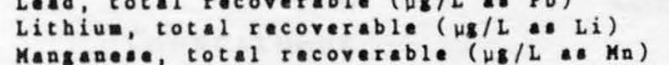 & $\begin{array}{r}80 \\
640\end{array}$ & $<10^{4}$ & $\begin{array}{l}2 \\
10 \\
80\end{array}$ \\
\hline 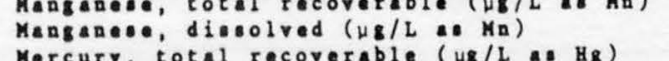 & 650 & 60 & 82 \\
\hline 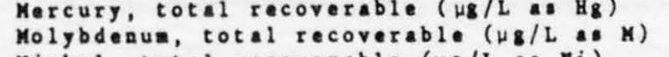 & $<1$ & & \\
\hline 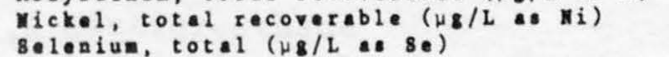 & $\begin{array}{l}96 \\
<1\end{array}$ & $\begin{array}{r}6 \\
<1\end{array}$ & $\varliminf_{<1}^{1}$ \\
\hline siver total recoverable (48/L $\left.\mathrm{ag} \mathrm{Ag}_{\mathrm{g}}\right)$ & $<1$ & $<i$ & 2 \\
\hline 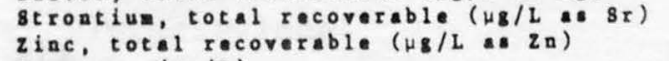 & $\begin{array}{l}90 \\
330\end{array}$ & $\begin{array}{r}110 \\
60\end{array}$ & $\begin{array}{r}130 \\
90\end{array}$ \\
\hline 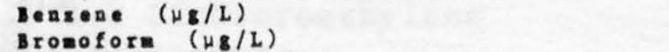 & $\begin{array}{l}<1 \\
<1\end{array}$ & $\ll_{1}^{1}$ & $\dddot{\varkappa}_{1}^{1}$ \\
\hline 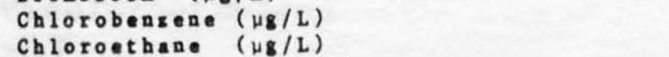 & $\ll_{<1}^{11}$ & $\ll_{<1}^{11}$ & $\ll_{1}^{1}$ \\
\hline 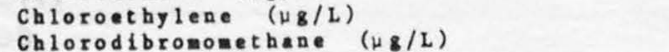 & $\begin{array}{l}<1 \\
<1\end{array}$ & $\overbrace{1}^{11}$ & $\begin{array}{c}1 \\
<1 \\
1\end{array}$ \\
\hline 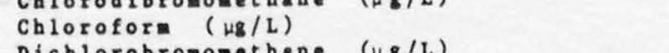 & $<i$ & $<_{<1}^{<}$ & $i_{<1}^{i}$ \\
\hline $\begin{array}{l}\text { Dichlorobromonet hane } \\
\text { carbontetrachloride }(\mu \mathrm{H} / \mathrm{g} / \mathrm{L}, \mathrm{L})\end{array}$ & $\ll 1$ & $<1$ & $\begin{array}{r}1 \\
<1\end{array}$ \\
\hline 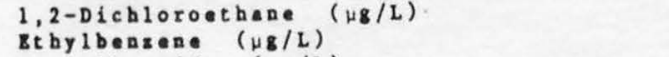 & $\ll 1$ & $\ll_{1}^{1}$ & $\begin{array}{l}11 \\
4\end{array}$ \\
\hline 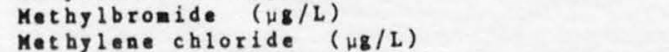 & $<_{1}^{11}$ & $<_{1}^{11}$ & $\varliminf_{1}^{11}$ \\
\hline 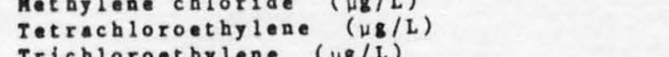 & $<1$ & $<1$ & $<1$ \\
\hline 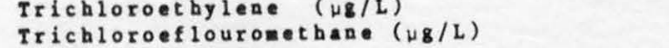 & $<1$ & $\ll 1$ & $\ll_{1}^{1}$ \\
\hline $\begin{array}{l}\text { Toluene }(\mathrm{H} / \mathrm{L}) \\
\text { Tolue }\end{array}$ & $<1$ & $<1$ & $\ll_{<1}^{11}$ \\
\hline 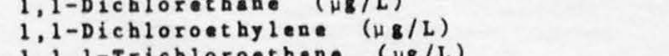 & $<1$ & $<_{<1}^{<1}$ & $<_{<1}$ \\
\hline 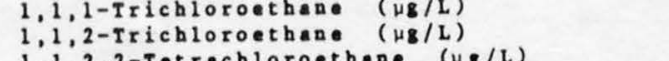 & $\begin{array}{l}1 \\
<1 \\
<1\end{array}$ & $\begin{array}{c}<1 \\
<1 \\
<1\end{array}$ & $\gtrless_{1}^{1}$ \\
\hline 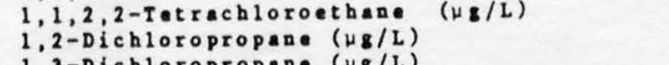 & $<1$ & $\begin{array}{l}1 \\
<1\end{array}$ & $\ll_{1}^{1}$ \\
\hline $\begin{array}{l}\text { 1,3-Dichloropropane (Hg/L) } \\
\text { 2-chloroethylvinylether (Hg/L) }\end{array}$ & $<1$ & $<1$ & $<1$ \\
\hline 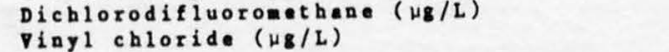 & $<1$ & $<1$ & $<1$ \\
\hline
\end{tabular}




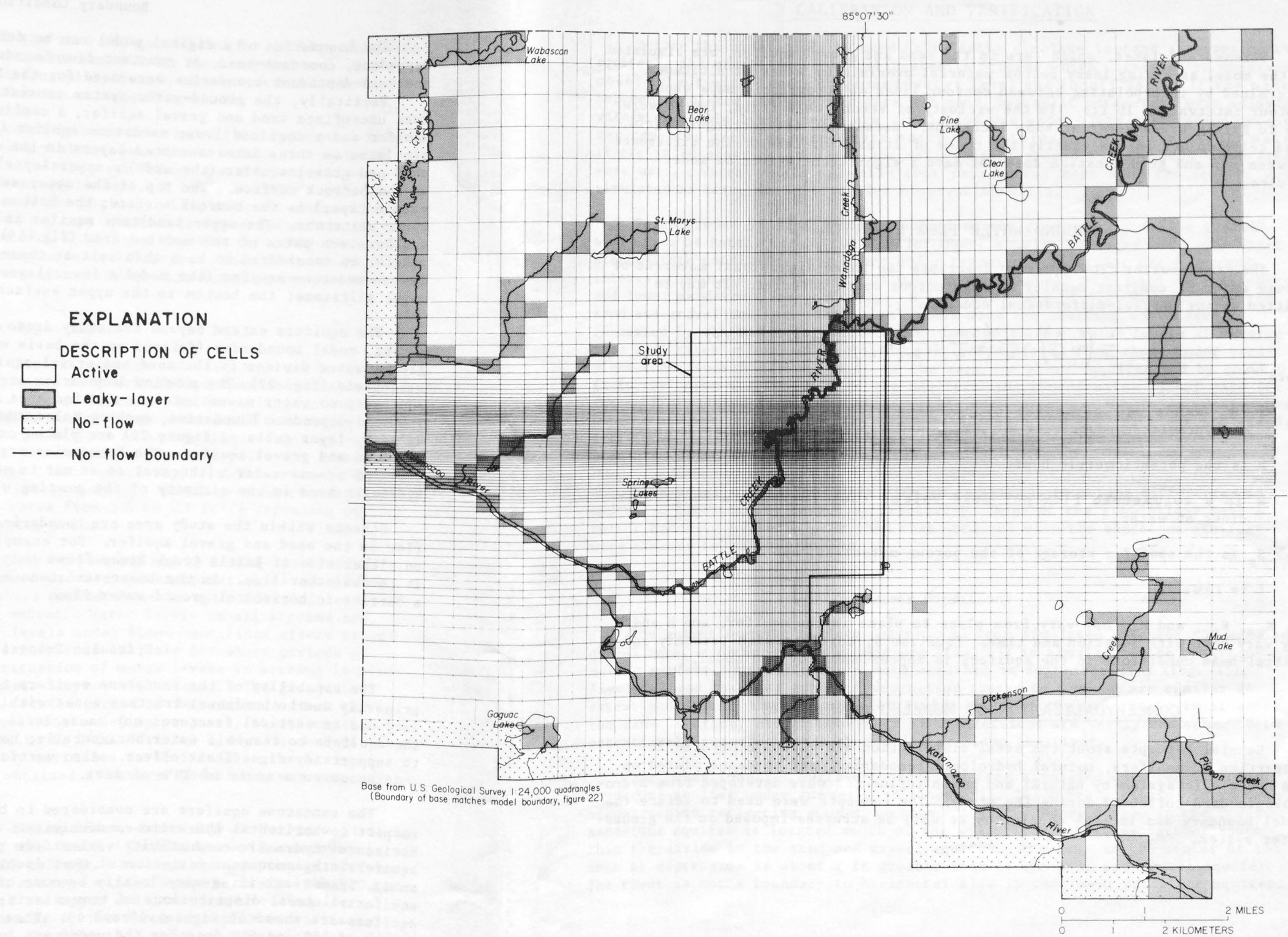

Figure 22.--Boundaries and grid spacing used in digital model. 
Streams and lakes, which are in the sand and gravel aquifer, are simulated in the model as having leaky bottom material overlain by water at altitudes determined by interpolating between contour lines on topographic maps whose contour interval is $10 \mathrm{ft}$. In the vicinity of Verona well field, levels were run to Battle Creek River at some locations. Because of the rectangular grid, between map and grid location does not have a significant effect on model results.

\section{GROUND-WATER FLOW EQUATION}

The ground-water flow equation describes the three-dimensional movement of ground water of constant density through porous earth material. It may be written as the partial-differential equation

$$
\frac{\partial}{\partial x}\left(x_{x x} \frac{\partial h}{\partial x}\right)+\frac{\partial}{\partial y}\left(x_{y y} \frac{\partial h}{\partial y}\right)+\frac{\partial}{\partial z}\left(x_{z z} \frac{\partial h}{\partial z}\right)-W=s_{5} \frac{\partial h}{\partial t}
$$

where

$x, y$, and $z$ are cartesian coordinates aligned along the major axes of hydraulic conductivity $\mathrm{K}_{\mathrm{xx}}, \mathrm{K}_{\mathrm{yy}}$, and $\mathrm{K}_{\mathrm{zz}}$;

$h$ is the potentiometric head;

$W$ is a volumetric flux per unit volume that represents sources or sinks of water

$\mathrm{S}_{\mathrm{s}}$ is the specific storage of the porous materials; and

$t$ is time. $\mathrm{S}_{\mathrm{s}}, \mathrm{K}_{\mathrm{xx}}, \mathrm{K}_{\mathrm{yy}}$, and $\mathrm{K}_{\mathrm{zz}}$ may vary from place to place in the aquifer, and $\mathrm{h}$ and $\mathrm{W}$
may vary both with location and time. Equation 1 , together with boundary and initial-head conditions in the aquifer, is approximated by the model.

\section{CONCEPTUALIZATION OF MODELED CONDITIONS}

General concepts about the areal distribution and values of hydraulic properties of aquifers, natural hydrologic boundaries, and stresses placed on the hydrologic system by natural and human influences were developed from hydro geologic data collected during the study. The concepts were used to def ine the model boundary and initial conditions as well as stresses imposed on the ground water system.
The boundaries of a digital model can be defined by no-flow, headdependent, constant-head, or constant-flux boundary conditions. Only no-flow and head-dependent boundaries were used for the Battle Creek model.

Vertically, the ground-water system consists of three aquifers--an uppermost unconfined sand and gravel aquifer, a confined-unconfined upper sandstone aquifer and a confined lower sandstone aquifer (fig. 3). The three aquifers ar simulated as three interconnected layers in the digital model. The top of the sand and gravel aquifer (the model's upper layer) is the water table; the botto is the bedrock surface. The top of the upper sandstone aquifer (the model's middle layer) is the bedrock surface; the bottom is the upper surface of the upper siltstone. The upper sandstone aquifer is missing in the western and southwestern parts of the modeled area (fig. 19). For modeling purposes, this aquifer is considered to be a thin unit at these locations. The top of the lower sandstone aquifer (the model's lower layer) is the lower surface of the upper siltstone; the bottom is the upper surface of the shale unit.

The aquifers extend beyond the study area. To limit their horizontal extent, model boundaries (defined on the basis of surface-water features and ground-water divides in the sand and gravel aquifer) were set 4 to $7 \mathrm{mi}$ from the well field (fig. 22). The no-flow boundaries are coincident for all three aquifers; no water moves into the modeled area from outside these boundaries. The head-dependent boundaries, such as Kalamazoo River and Wabascon Creek (shown as leaky-layer cells on figure 22) are placed only in the layer that simulates. the sand and gravel auifer. The boundaries are distant eaug from the major areas of ground-water withdrawal so as not to effect the calculation of hydraulic head in the vicinity of the pumping wells.

Streams within the study area are boundaries for horizontal ground-water flow in the sand and gravel aquifer. For example, ground water in this aquifer on either side of Battle Creek River flows only to or from the river, not beyon
it to the other side. In the lower sandstone aquifer, however, the river is not a barrier to horizontal ground-water flow.

\section{Hydraulic Properties}

The capability of the sandstone aquifers to transmit water horizontally is primarily due to horizonal fracture zones within the rocks. Secondary permeability due to vertical fractures may cause local differences in the capability of the aquifers to transmit water horizontally; however, there is little evidence to support any significant effect. Also vertical fractures are not known to be continuous on a scale of 10 's of feet.

The sandstone aquifers are considered to be homogeneous and isotropic with respect to horizontal hydraulic conductivity. Although it is known that horizontal hydraulic conductivity varies from place to place in the sandstone aquifers, the amount of variation at most locations, based on available data, is small. Transmissivities vary locally because of varying thickness of the

aquifers. Areal distributions of transmissivity used to simulate the sandstone aquifers are shown on figures 18 and 19. These figures represent constant values of 150 and $550 \mathrm{ft} / \mathrm{d}$ for the upper and lower sandstone aquifers respectively. 
The hydraulic conductivity of the sand and gravel aquifer differs depending on the type of deposit. Till has a lower conductivity than outwash and channel simulate the sand and gravel aquifer are shownanic conductivi

The vertical flow of ground water is more restricted than horizontal flow rom model simulations, upper sandstone aquifers were detern. $10^{-2}$ per day, respectively, deposits. Based on analy, for areas underlain by till, outwash, and channel pper and lower sands value was raised sandstone aquifers of $4 \times 10^{-3}$ per day was initially used. This value of $1.2 \times 10^{-3}$. value of $1.2 \times 10^{-3}$ was used because of more clay-rich deposits in that area.

Hydrologic Stresses

The aquifers are stressed by natural recharge and discharge and by groundater pumpage. Most recharge originates as precipitation that infiltrates the soil and percolates to the sand and gravel aquifer. Recharge is greatest in the recharge rate used in the model for these deposits is $13 \mathrm{in./yr}$. Recharge is less in metropolitan areas and areas of till; the recharge rates used in the model for these deposits are 8 and 10 in./yr, respectively. Local recharge occurs where supply wells are near strean water is induced from the streams by pumping. Baseflow measurement indicate that water is induced at rates from 1.0 to $3.5 \mathrm{ft} / \mathrm{s}$ depending on pumping rates and locations of pumping wells.

Ground-water is discharged mostly by pumping and by leakage to streams, akes, and swamps. Discharge by ground-water evapotranspiration is considered insignificant because the places where ground water is within $5 \mathrm{ft}$ of land surface are few and small in areal extent. Water levels in all streams are assumed to be constant. High water levels under flood conditions affect ground water levels and flow directions near streams but only for short periods of time. During other periods, the fluctuation of water levels in streams is mino and the effects on priond-water levels are not meared differ gaging station stren of streamber sieve analyses of bottons initially estimated to fted $t$ $4 \mathrm{ft} / \mathrm{d}$ during model calibration.

Ground-water pumpage stresses the aquifers, especially in Verona well field and in the industrial area south of the field. Combined, continuous pumpage of several industries is 3,000 to $6,000 \mathrm{gal} / \mathrm{min}$. Average summer pumpage at Verona ell field is about $8,000 \mathrm{gal} / \mathrm{min}$; average winter pumpage is about $6,300 \mathrm{gal}$ min. Most wells produce from both the upper and lower sandstone aquifers. In the model, distribution of pumpage among aquifers was accomplished with a multiaquifer well-simulation program (M. G. McDonald, written communication, 1984) similar to a well-simulation technique outlined by Bennett and others (1982).
Before the model could be used to reliably simulate imposed stresses on the aquifers, the model had to be calibrated, a process which consisted of comparing model output with measured ground-water level and runoff data. If the match between simulated and measured data was poor, hydraulic parameters were adjusted within plausible limits and a new simulation was made. This calibration process was repeated until an acceptable match was attained. For calibration, water levels in 80 observation wells and estimates of ground-water runoff at 9 sites were used. Water levels in wells that represented more than one aquifer were simulated as being in multiaquifer observation wells.

To determine if steady-state conditions could accurately define groundwater flow at Battle Creek, two similar model simulations were made--one under steady-state conditions, the other under transient conditions for a 3 -month interval. Storage coefficients of 0.00015 and 0.000015 were used for the upper and lower sandstone, respectively. A specific yield of 0.15 was used for the sand and gravel aquifer. Both simulations used the starting water levels generated by the model for winter pumping conditions. Water levels at observation well sites under steady-state conditions differed from those under transient conditions by about $1.0 \mathrm{ft}$ in the sand and gravel aquifer and by about 0.6 $\mathrm{ft}$ in the upper and lower sandstone aquifers. The ground-water runoff rate for the entire modeled area under steady-state conditions was $0.6 \mathrm{ft}^{3} / \mathrm{s}$ greater than under transient conditions. The small differences between transient and steadystate model results indicates that the ground-water system can be accurately simulated using steady-state conditions.

Some model simulations were made in an attempt to define differences in hydraulic conductivity caused by fracturing. None of the simulations gave a better match to measured data than that obtained when the sandstone aquifers were assumed to be homogeneous.

\section{Summer Conditions}

The potentiometric surface constructed from simulated data for the sand and gravel aquifer under summer conditions (fig. 23) is similar to the potentiometric surface constructed from data obtained in September 1983 (fig. 15). simulated and observed cones of depression caused by pumping are similar in extent and depth. The ground-water divide south of the well field is at about the same location, and ground-water flow directions are nearly the same. Both potentiometric-surface maps show a divide along the river.

The potentiometric surface constructed from simulated data for the lower andstone aquifer under summer conditions (fig. 24) shows a single, large cone of depression reflecting summer pumpage. A ground-water divide in the lower sandstone aquifer is located south of the well field but it is farther south than the divide in the sand and gravel aquifer. Drawdown in the center of the cone of depression is about $2 \mathrm{ft}$ greater than in the sand and gravel aquifer. The river is not a boundary to horizontal flow in the lower sandstone aquifer. 


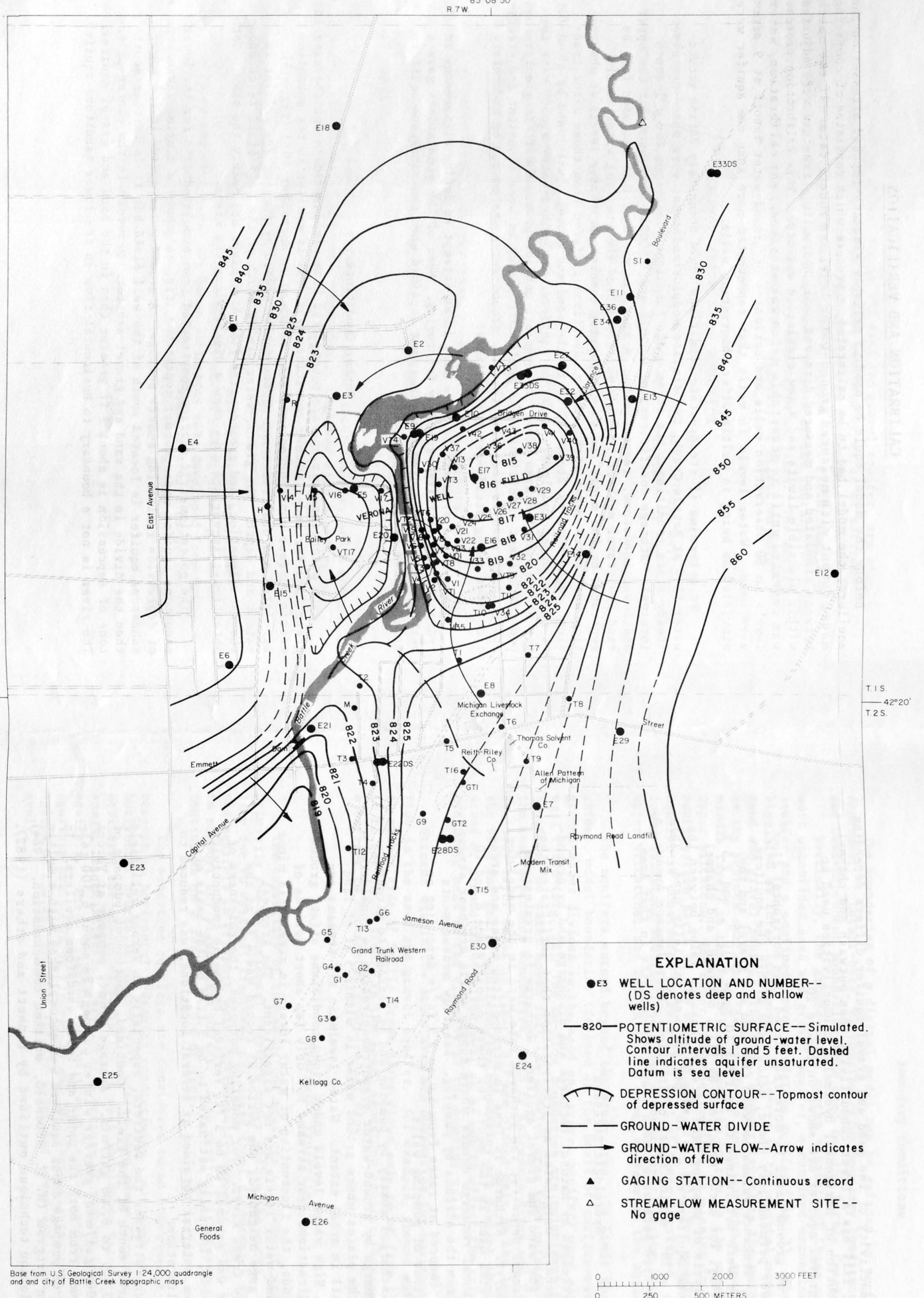

Figure 23.--Simulated potentiometric surface of sand and gravel aquifer under summer conditions. 


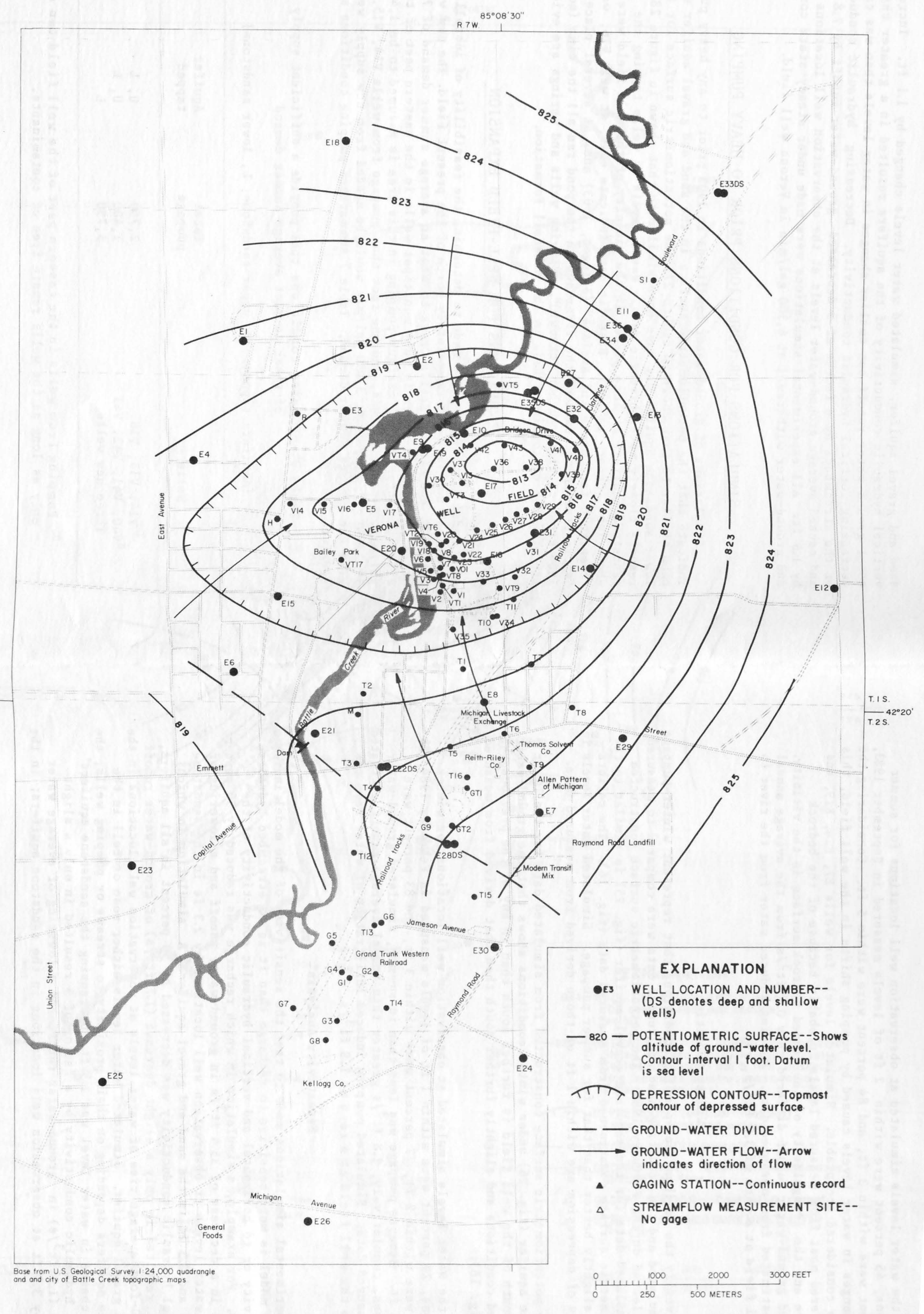


of the water levels simulated at observation well locations for summer conditions, 45 percent were within $2 \mathrm{ft}$ of levels measured in September 1983 63 percent were within $3 \mathrm{ft}$, and 84 percent were within $5 \mathrm{ft}$. Considering the rapid changes in water levels caused by pumping shifts in the well field, thi match is considered acceptable. Simulated levels for we1ls E7, E24, E29, and E30 differed most from measured levels, probably because of the bedrock structure and the irregularity of the eroded bedrock surface in the vicinity. simulated ground-water runoff differed only $0.5 \mathrm{ft}^{3} / \mathrm{s}$ from the average annual runoff estimated from measured data. Pumping induced water from the river to the well $\mathrm{field}$ at a rate of $3.0 \mathrm{ft}^{3} / \mathrm{s}$.

\section{Winter Conditions}

To verify the calibration, pumping conditions that represent winter pumpage were simulated and the resulting head and runoff data were compared to measured data collected during February 1984. The potentiometric surface constructed from simulated data for the sand and gravel aquifer (fig. 25) is similar to the potentiometric surface constructed from measured data (fig. 16). The calibration is slightly better than that for summer pumpage. Simulated water levels in the cones of depression are within $1 \mathrm{ft}$ of those derived from measured data.

The potentiometric surface constructed from simulated data for the lower sandstone aquifer (fig. 26) under winter conditions shows that the ground-wate divide south of the well field is further south than in any of the previous simulated conditions and slightly further south than that derived from measured data (fig. 16).

of the water levels simulated at observation well locations for winter conditions, 29 percent were within $1 \mathrm{ft}$ of levels measured in February 1984, 53 percent were within $2 \mathrm{ft}, 77$ percent were within $3 \mathrm{ft}$, and 83 percent were within $5 \mathrm{ft}$. Because pumpage was less than in runoff was, cumulatively, $1.8 \mathrm{ft}^{3} / \mathrm{s}$ greater than annual average runoff estimated from measured data. Simulated pumping induced infiltration of water from the river to the well $\mathrm{field}$ at a rate of $1.9 \mathrm{ft}^{3} / \mathrm{s}$.

Sensitivity Analysis

Experimental simulations made to test the sensitivity of the model indicate that the model is more sensitive to recharge than it is to streambed hydraulic conductivity or to horizontal and vertical hydraulic conductivity of the aquifers. For example, a simulation in which recharge was reduced by 50 percent resulted in a decrease of $35.4 \mathrm{ft} / \mathrm{s}$ in ground-water runoff and a lowering of averifers and $2.3 \mathrm{ft}$ in the sandston aquifers and simulation in which however, resulted in ond all aquifers, how ans sand and a

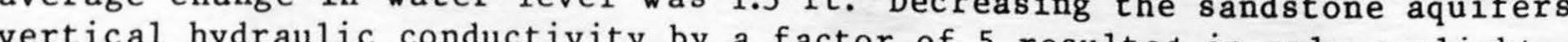
作 levels by $3.5 \mathrm{ft}$ at observation well locations in the sandstone aquifers; in the sand and gravel aquifer, simulated water levels changed by $1.1 \mathrm{ft}$. Increasing ertical hydraulic conductivity of the aquifers resulted in a greater change in total ground-water runoff but smaller changes in water levels than was caused by decreasing vertical hydraulic conductivity. Decreasing hydraulic conductiyity of the streambeds by a factor of 5 decreased ground-water runoff by $7.8 \mathrm{ft} / \mathrm{s}$ and caused average ground-water levels at the observation well locations to rise by $1.6 \mathrm{ft}$. All experimental simulations were made under steady-state conditions and ground-water withdrawal at $6,300 \mathrm{gal} / \mathrm{min}$ in Verona well field.

\section{SIMULATIONS FOR CONDITIONS PRIOR TO HEAVY PUMPING}

Simulations of ground-water conditions in 1903 prior to any heavy pumping indicate that the potentiometric surface in the sand and gravel aquifer may have been similar to that shown in figure 27; the potentiometric surface for the lower sandstone aquifer may have been similar to that shown in figure 28 . The results closely match historic data. Water levels in wells tapping the sandstone aquifers at some places in the vicinity of the well field were at or and "rose to 6 feet above the surface" (Bridgen, 1903) and, at several places, "rose to 6 seces, springs along the bank of the river and in the pond ran all the time (note on the presence of confining beds in the Marshall Formation.

\section{SIMULATIONS FOR WELL-FIELD EXPANSION}

Model simulations were made to determine the feasibility of installing new municipal supply wells immediately north of the present field. The new wells are needed by the city of Battle Creek to meet an average summer demand of 7,900 gal/min. Because water in many municipal wells in the eastern part of the wel field is contaminated, maximum pumping in this area is assumed to be 1,400 $\mathrm{gal} / \mathrm{min}$. Because of this, and the fact that pumpage from wells V14, v15, and $\mathrm{v} 16$ is $2,750 \mathrm{gal} / \mathrm{min}$, about $3,750 \mathrm{gal} / \mathrm{min}$ would be needed from new supply wells to meet the average summer demand. Table 7 summarizes pumping conditions and the aquifers tapped.

Table 7.--Pumping conditions that provide a sufficient supply of water to meet average summer deman

[Aquifers tapped: U, upper sandstone; L, lower sandstone]

\begin{tabular}{cll}
\hline We11s & $\begin{array}{l}\text { Total } \\
\text { pumpage }\end{array}$ & $\begin{array}{l}\text { Aquifer } \\
\text { tapped }\end{array}$ \\
\hline V14, V15, V16 & 2,750 & U, L \\
V40, V41, V42, V43 & 1,400 & U, L \\
Three new we11s & 3,750 & L \\
\hline
\end{tabular}

a Pumping from wells in the eastern part of the well field can continue only as long as the wells remain free of contaminants. 


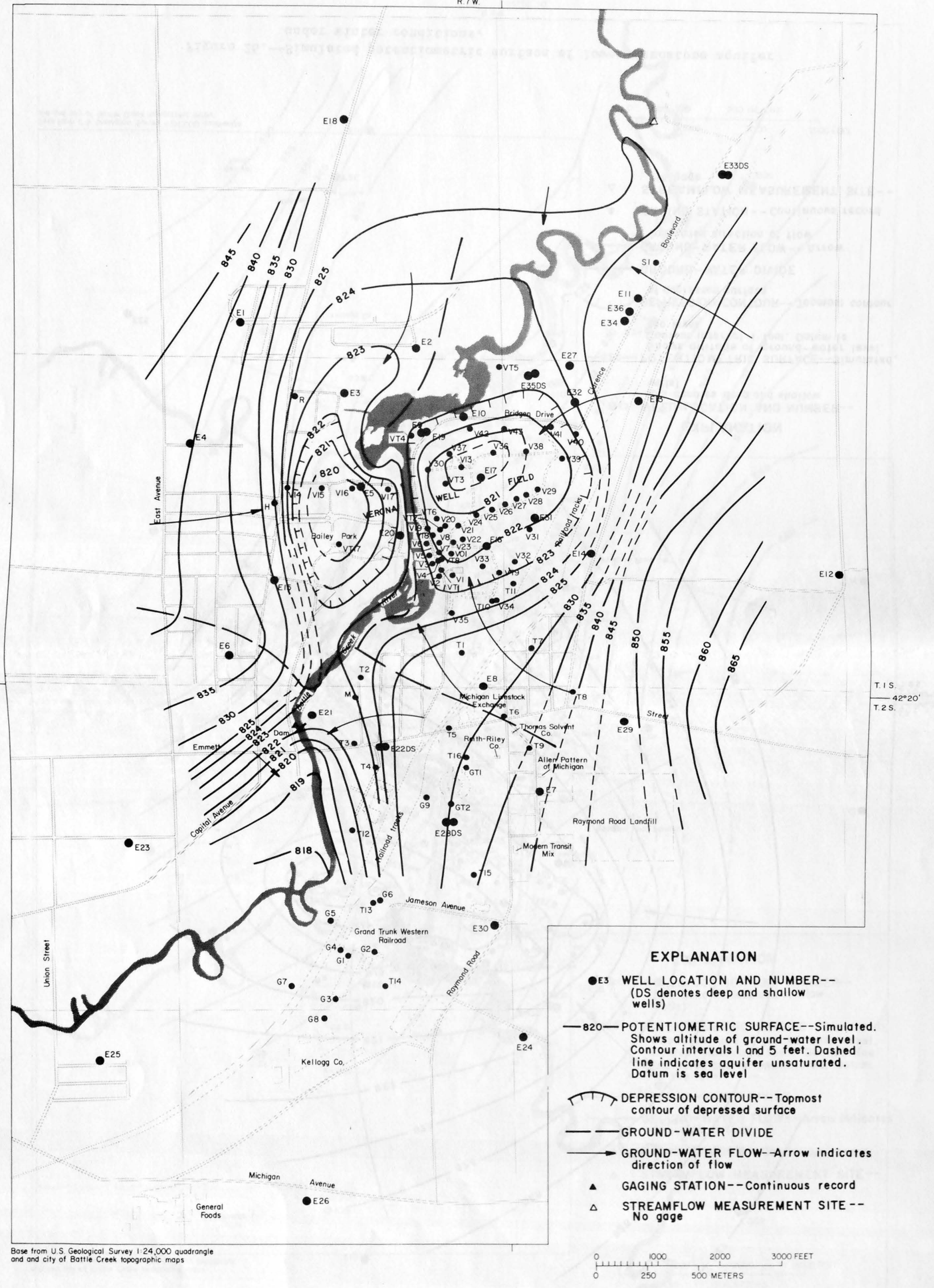

Figure 25.--Simulated potentiometric surface of sand and gravel aquifer 


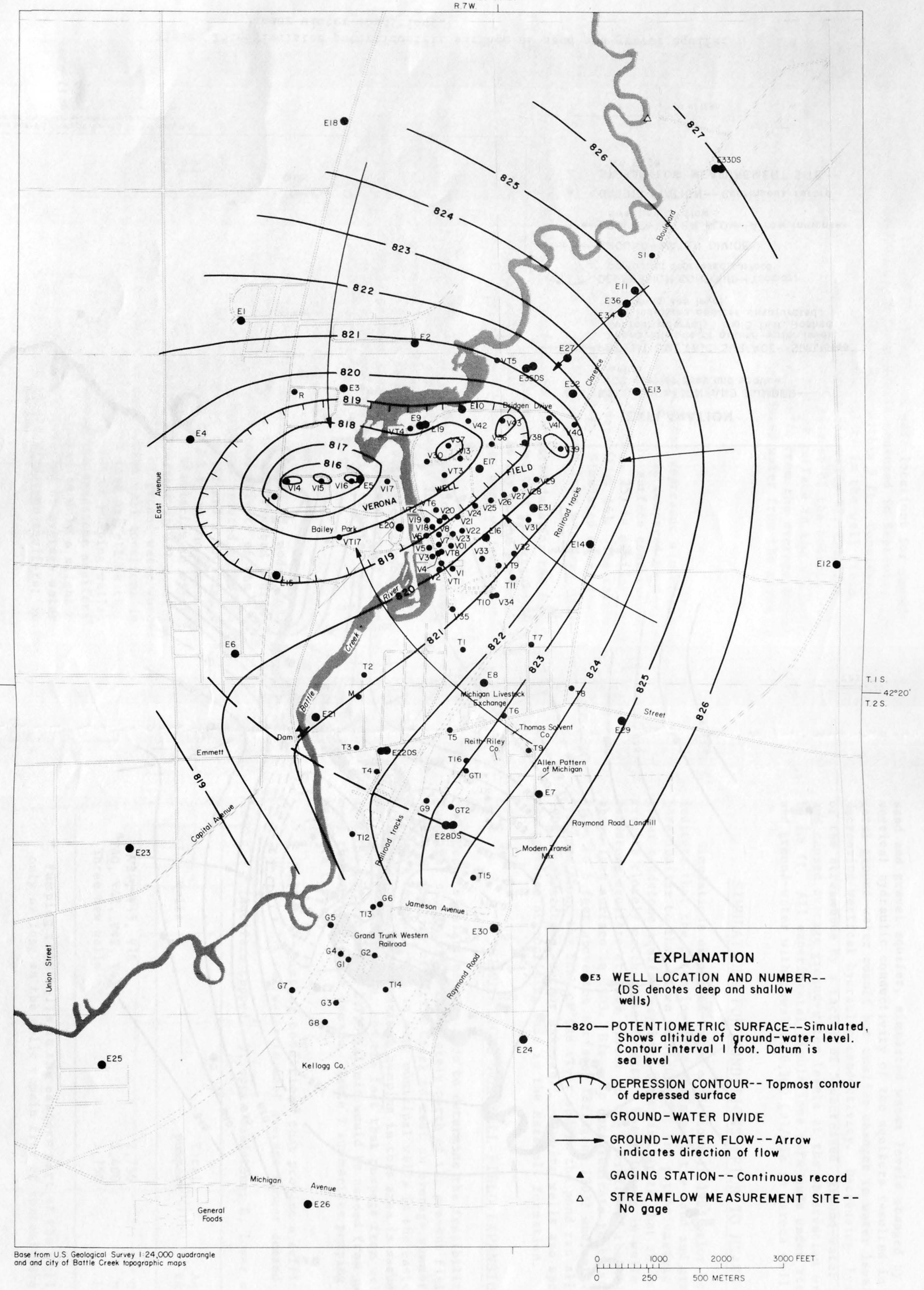

Figure 26.--Simulated potentiometric surface of lower sandstone aquifer under winter conditions. 


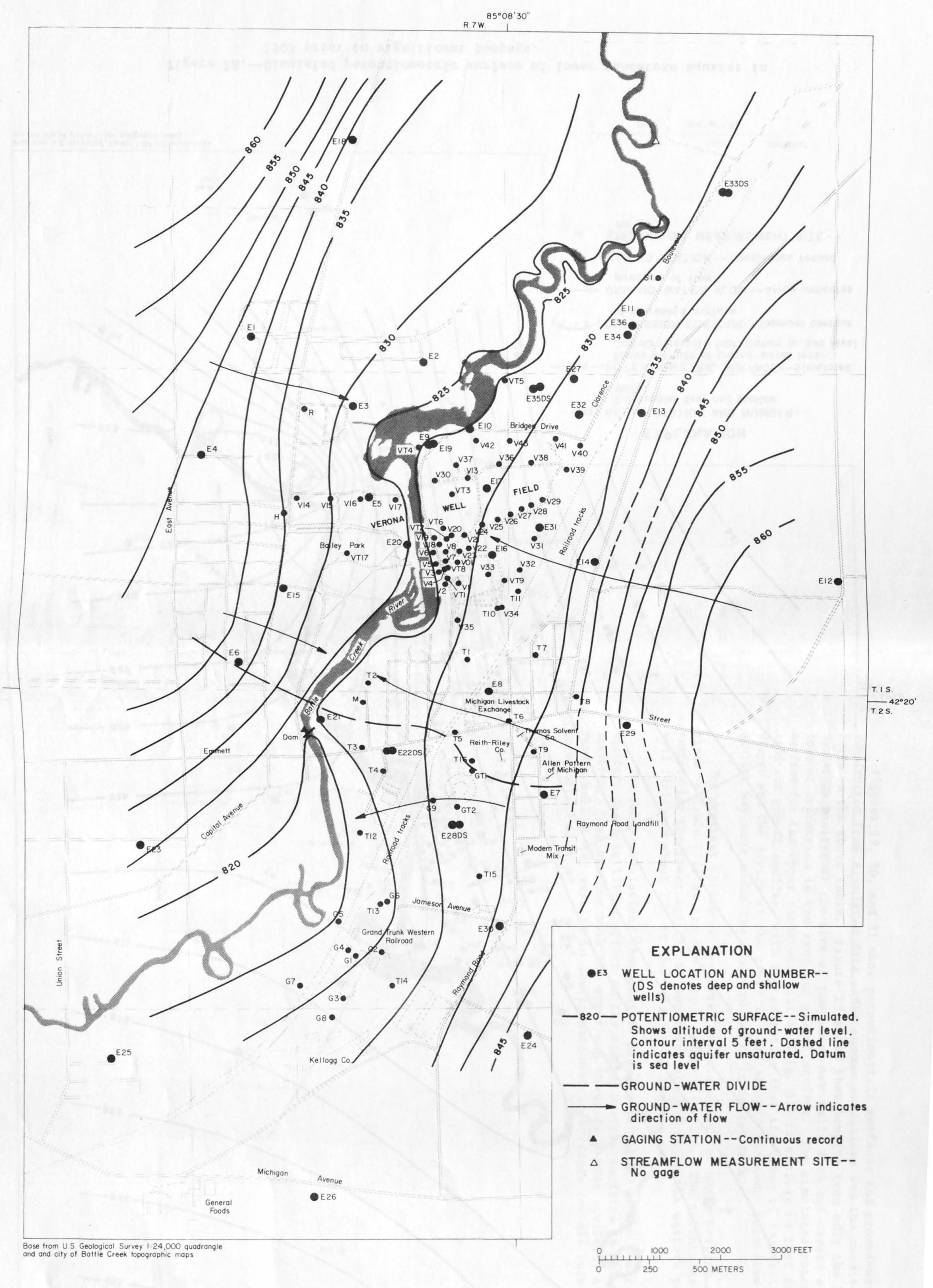


Do

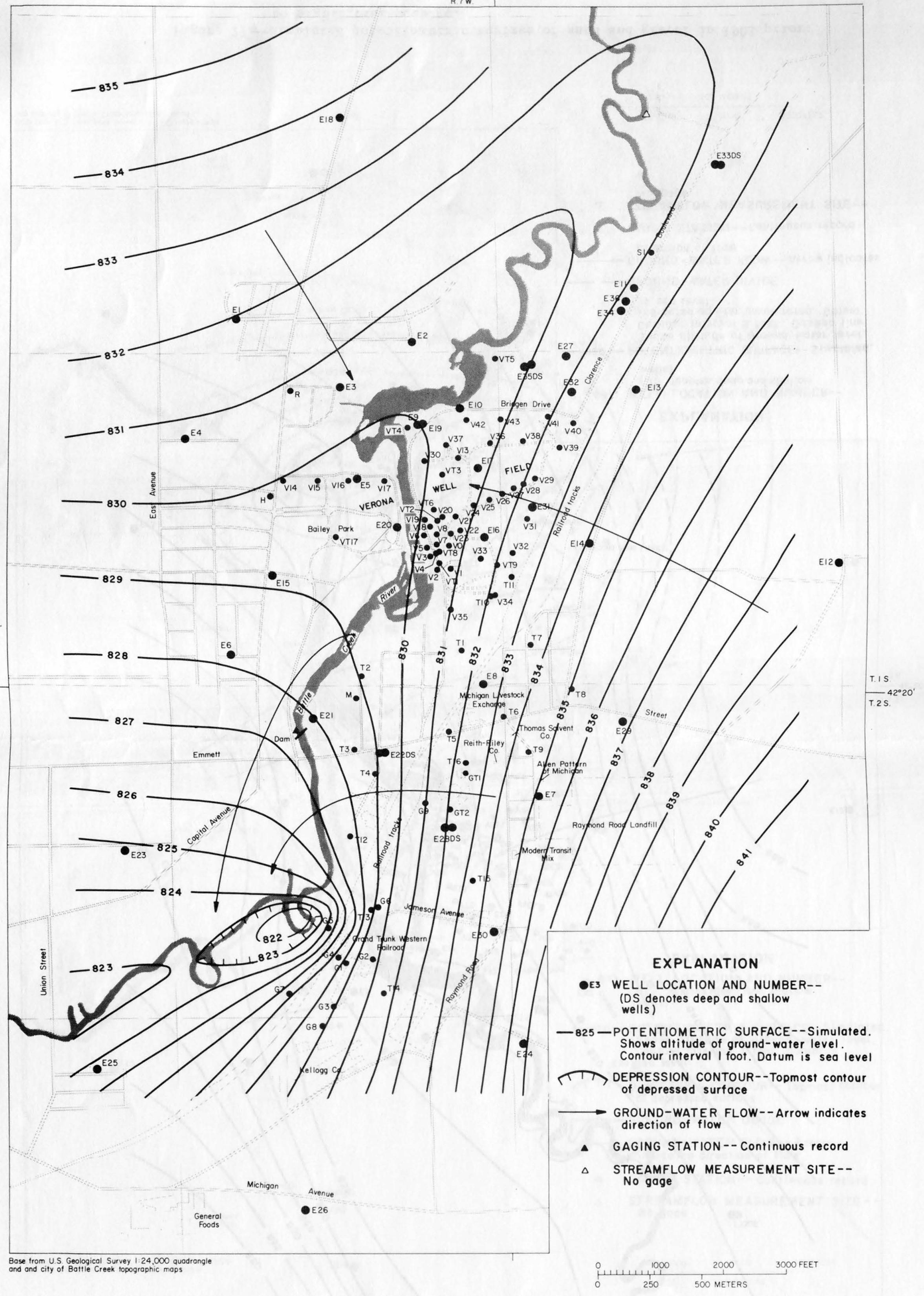

Figure 28.--Simulated potentiometric surface of lower sandstone aquifer in 1903 prior to significant pumpage. 
Figures 29,30 , and 31 show potentiometric surfaces and ground-water flow constructed from simulated data under summer conditions and the conditions set forth in the above table. Figure 29 shows that pumping from only the lower sandstone aquifer at the site of the three new wells does not create a separate cone of depression in the sand and gravel aquifer. The simulated potentiometric surface for the upper sandstone aquifer (fig. 30) is similar to that for the sand and gravel aquifer, with the exception that the cones of depression are deeper and the divide at the river is less sharply defined. Some flow in this aquifer may move under the river to wells in Bailey Park.

The greatest stress on the lower sandstone aquifer under pumping conditions given in table 7 is by the new supply wells (fig. 31). The potentiometric surface for the lower aquifer is depressed about $5 \mathrm{ft}$ in the western part of the well field and about $7 \mathrm{ft}$ in the vicinity of the new wells.

The above simulations show that if pumping is only from the lower sandstone aquifer, there is little effect on the potentiometric surfaces in the other two aquifers. Pumping from both the upper and lower sandstone aquifers, as in the Verona well field, results in the potentiometric surfaces for all three aquifers being effected. 

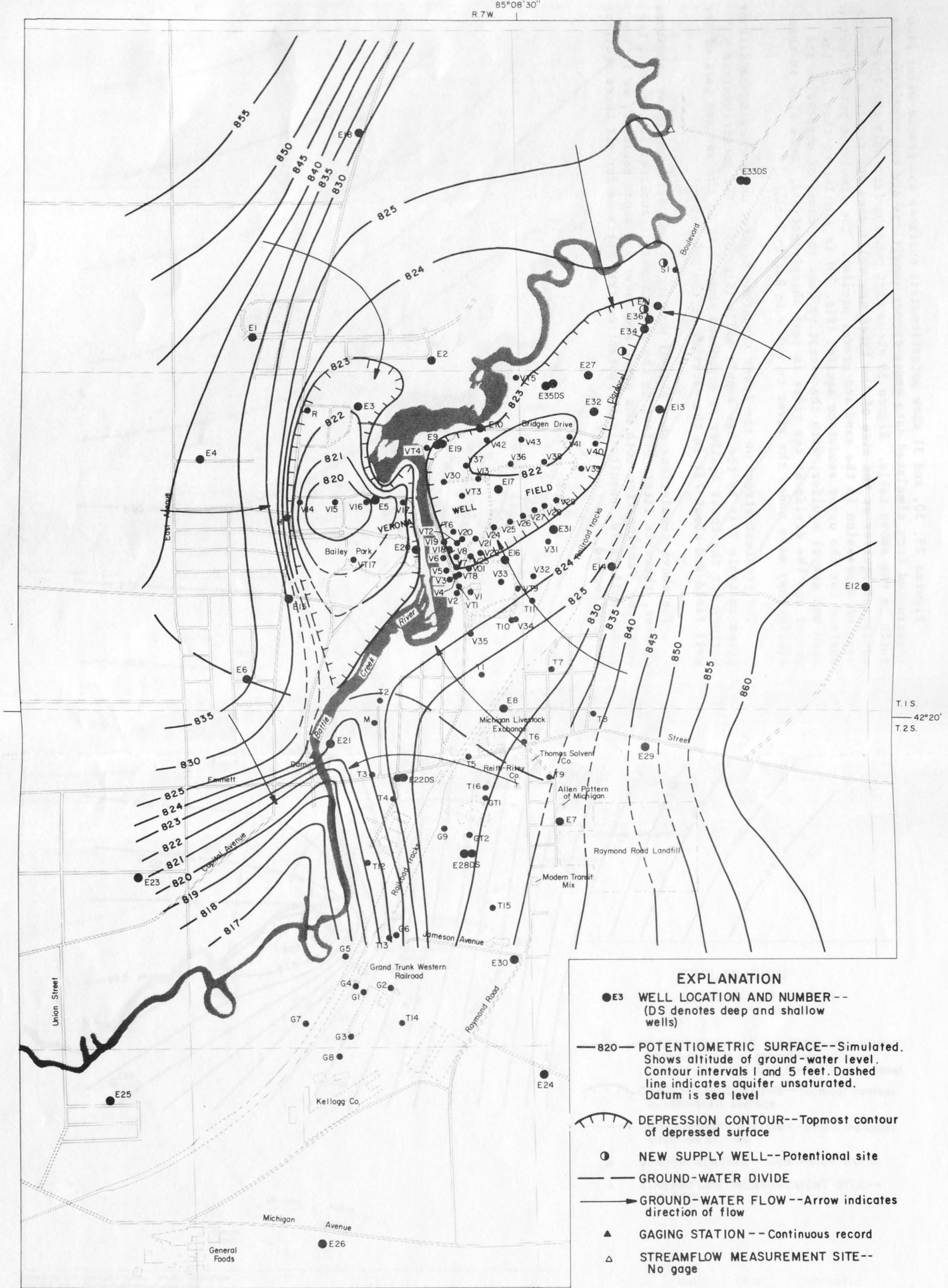
EXPLANATION
-e3 WELL LOCATION AND NUMBER - ( $D S$ denotes deep and shallow
wells) -820- POTENTIOMETRIC SURFACE--Simulated
Shows altifude of ground-water level.
Contour intervals 1 and 5 feet. Dashed
line indicates aquifer unsaturated.
Dafum is sea level
- NEW SUPPLY WELL--Potentional site $\longrightarrow$ GROUND-WATER DIVIDE
GROUND-WATER FLOW--Arrow indicates
direction of flow
- gaging STATION--Continuous record
$\triangle$ STREAMFLOW MEASUREMENT SITE-- No gage

Bose from U.S. Geological Survey I: 24,000 quadrongle
and ond city of Battle Creek topographic maps

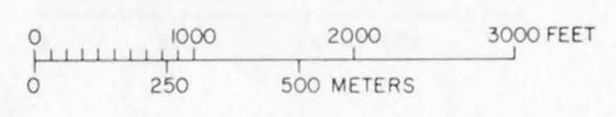

Figure 29.--Simulated potentiometric surface of sand and gravel aquifer under summer conditions with three new supply wells immediately north of Verona well field pumping a total of 3,750 $\mathrm{gal} / \mathrm{min}$ from the lower sandstone aquifer (supply wells V14, V15, V16 pump a total of 2,750 $\mathrm{gal} / \mathrm{min}$; supply wells $\mathrm{V} 40, \mathrm{~V} 41, \mathrm{~V} 42$, and $\mathrm{V} 43 \mathrm{pump}$ a total of $1,400 \mathrm{gal} / \mathrm{min}$. Interdiction wells not simulated). 


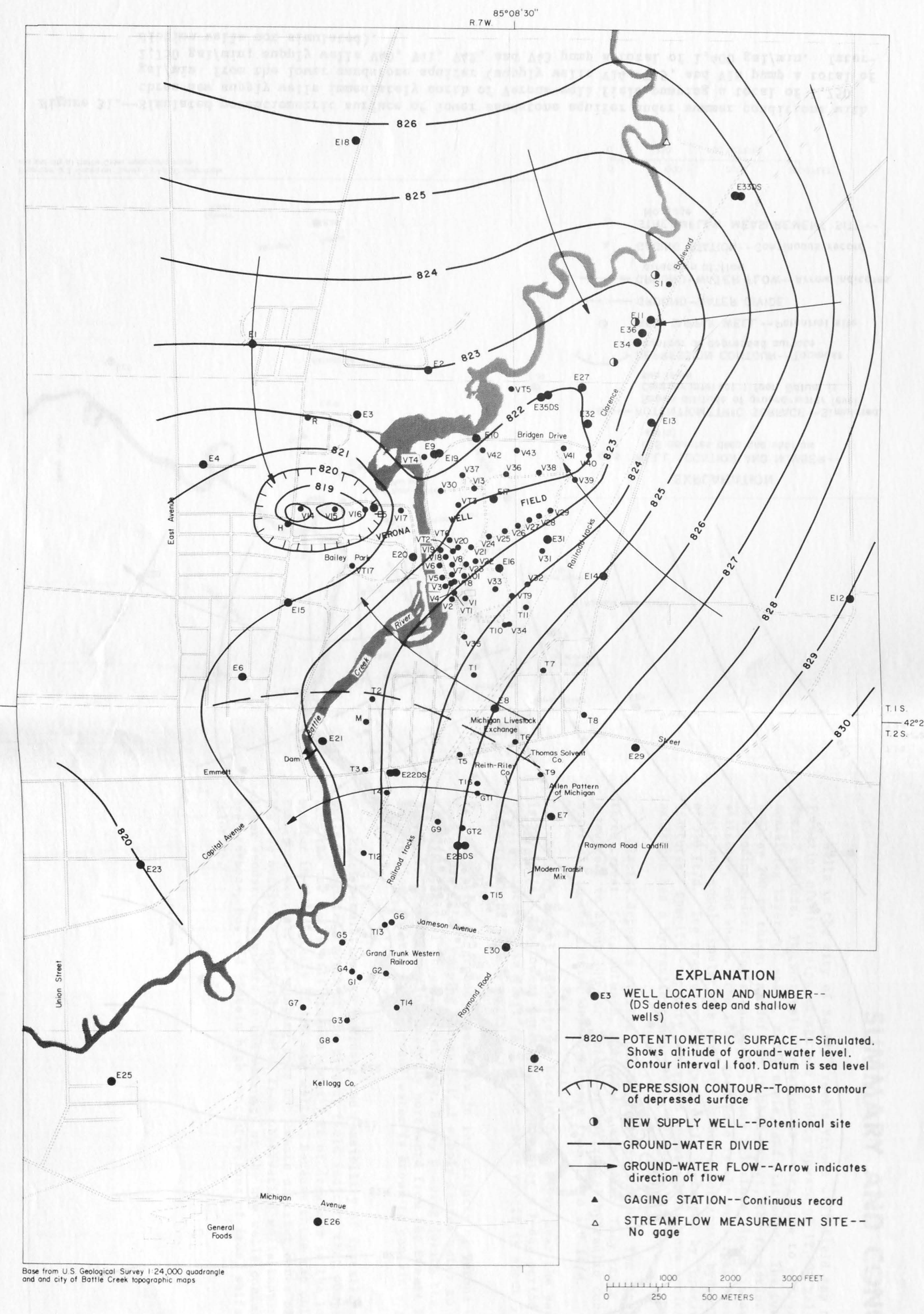

Figure 30.--Simulated potentiometric surface of upper sandstone aquifer under summer conditions with three new supply wells immediately north of Verona well field pumping a total of 3,750 $\mathrm{gal} / \mathrm{min}$ from the lower sandstone aquifer (supply wells V14, V15, and V16 pump a total of $2,750 \mathrm{gal} / \mathrm{min}$; supply wells $\mathbf{V} 40, \nabla 41, \mathrm{~V} 42, \mathrm{~V} 43$ pump a total of $1,400 \mathrm{gal} / \mathrm{min}$. Interdiction wells not simulated). 

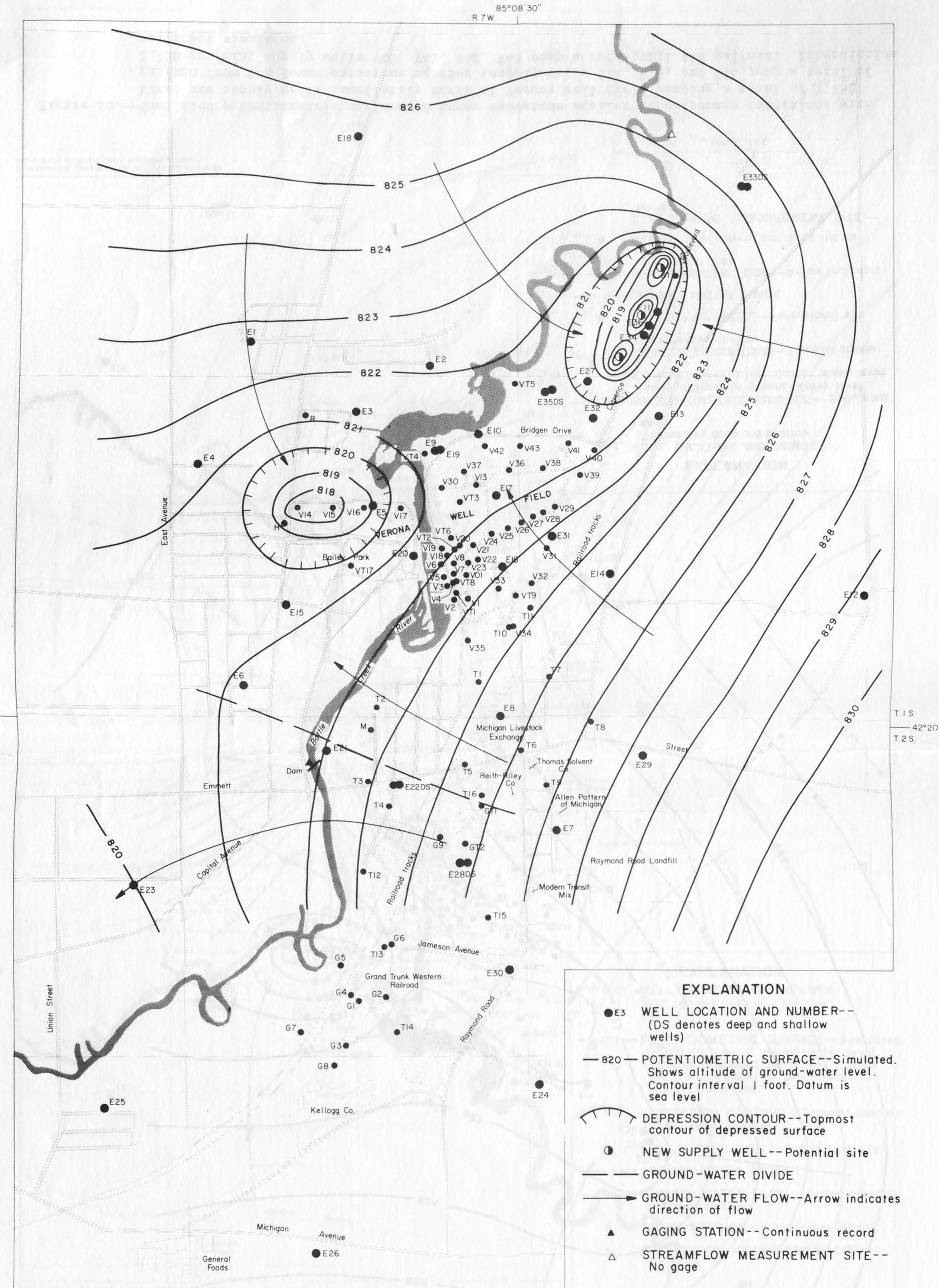

\section{EXPLANATION}

- 3 well location and nUmber-(DS denotes deep and shallow wells)

-820-POTENTIOMETRIC SURFACE--Simulated. Shows altitude of ground-water level. Contour interval I foot. Datum is Contour in
sea level

$\lceil T$ DEPRESSION CONTOUR--TOPMOST contour of depressed surface

- NEW SUPPLY WELL-- Potential site - GROUND-WATER DIVIDE

- GROUND-WATER FLOW--Arrow indicates direction of flow

- gaging STATION--Continuous record

$\triangle$ STREAMFLOW MEASUREMENT SITE-No gage

Figure 31.--Simulated potentiometric surface of lower sandstone aquifer under summer conditions with three new supply wells immediately north of Verona well field pumping a total of 3,750 $\mathrm{gal} / \mathrm{min}$ from the lower sandstone aquifer (supply wells V14, V15, and V16 pump a total of $2,750 \mathrm{gal} / \mathrm{min}$; supply wells V40, V41, V42, and V43 pump a total of $1,400 \mathrm{gal} / \mathrm{min}$. Interdiction wells not simulated). 


\section{SUMMARY AND CONCLUSIONS}

Wells in the city of Battle Creek's Verona well field tap the Marshall Formation of Mississippian age and produce upward of 12,000 gal/min during peak demand periods. The Marshall Formation is a very fine to medium sandstone containing layers of shale, sandy shale, and siltstone. The formation is as much as $200 \mathrm{ft}$ thick. As defined in this report, the formation consists of, in descending order: Upper sandstone, upper siltstone, lower sandstone, lower siltstone, and shale. The lower sandstone is the principal aquifer; pumping tests and model simulations indicate it has a horizontal hydraulic conductivity of $550 \mathrm{ft} / \mathrm{d}$. Its transmissivity is greatly increased by "openings" or fractures. Specific-capacity tests and model simulations indicate the upper sandstone has a hydraulic conductivity of $150 \mathrm{ft} / \mathrm{d}$.

Glacial deposits overlie the Marshall Formation. The deposits consist of three types: Till, outwash, and channel deposits. They range in thickness from a few feet to about $100 \mathrm{ft}$. Values of horizontal hydraulic conductivities for materials in the glacial deposits range from 15 to $110 \mathrm{ft} / \mathrm{d}$.

Average annual discharge of Battle Creek River near the Verona well field is $200 \mathrm{ft}^{3} / \mathrm{s}$. The lowest expected discharge for a 7-day period having a 10-year recurrent interval is $33 \mathrm{ft}^{3} / \mathrm{s}$. Ground-water runoff is about $55 \mathrm{ft} / \mathrm{s}$. Recharge ranges from 8 to 13 in./yr.

Velocities of ground-water flow in the vicinity of Verona well field range from 1 to $4 \mathrm{ft} / \mathrm{d}$. Pumping for municipal supply causes water to flow to the well field from several thousand feet away. Heavy pumping during the summer months causes ground water to flow directly northward from the Emmett St-Raymond Rd intersection, an area where ground water is known to contain significant contaminants.

Model simulations to evaluate the feasibility of installing new supply wells immediately north of the present field indicate that pumping $3,750 \mathrm{gal} / \mathrm{min}$ from the new wells will produce about $7 \mathrm{ft}$ of drawdown in the lower sandstone aquifer in the vicinity of the new wells. Because these tap only the lower sandstone aquifer, the pumping does not create distinct cones of depression in the two overlying aquifers. Water from observation wells tapping the upper and lower sandstone aquifers in the vicinity of the new wells contained no volatile hydrocarbons, but did contain high concentrations of iron, sulfate, sodium, and chloride. 


\section{REFERENCES CITED}

Bridgen, W. W., 1903, Report on wells put down northeast of Verona: Report to Special Committee on Water Supply, 4 p.

Bennett, G. D., Kontis, A. L., and Larson, S. P., 1982, Representation of multiaquifer well effects in three-dimensional ground-water flow simulation: National Water Well Association; Ground Water, vol. 20, no. 3, p. 334-341.

Ecology and Environment, Inc., 1982, Battle Creek ground water survey, 49 p., 11 figs.

Environmental Data Inc., 1982, Results of hydrogeological investigation at the heavy equipment repair shop, Grand Trunk Western Railroad, Battle Creek, Michigan, in August 1982: 34 p., 1 fig.

Ho1st, T. B., 1983, Regional jointing in the northern Michigan Basin, in Geology: Geological Society of America, Inc., p. 273-277.

Leverett, Frank, 1918, The country around Camp Custer: U.S. Geological Survey Administrative report, p. 16

McDonald, M. G., and Harbaugh, A. W., 1983, A modular three-dimensional finitedifference ground-water flow model: U.S. Geological Survey Open-File Report $83-875$, p. 528 .

Monnett, V. B., 1948, Mississippian Marshall Formation of Michigan: American Association of Petroleum Geologists Bulletin, vol. 32, pp. 629-688.

National Oceanic and Atmospheric Administration, 1981, Climatological data annual summary: U.S. Department of Commerce, v. 96 , no. 13,19 p.

Newcombe, R. B., 1933, Oil and gas fields of Michigan: Michigan Department of Conservation, Geological Survey Division, publication 38, series 32 , p. 293.

Prouty, C. E., 1983, The tectonic development of the Michigan Basin intrastructures, in Tectonics, structure and karst in northern lower Michigan Michigan Basin Geological Society, 1983 Field Conference, p. 42-46.

Stearns, M. D., 1933, The petrology of the Marshall Formation of Michigan: Journal of Sedimentary Petrology, vol. 3, pp. 99-112.

Stearns, M. D., and Cook, C. W., 1931, A petrographic study of the Marshall Formation and its relation to the sand of the Michigan Series Formation: Michigan Academy of Science, Arts, and Letters, vol. XVI, pp. 429-437.

Theis, C. V., 1935, The relation between the lowering of the piezometric surface and the rate and duration of discharge of a well using ground-water storage: American Geophysical Union Trans., v. 16, p. 519-524.
Thom W. A 1931, A study of the Marshall Formation in Michigan: Michigan Academy of Science, Arts, and Letters, vol. XIV, pp. 487-498.

U.S. Geological Survey, 1982, Water resources data for Michigan, 1981: U.S. Geological Survey Water-Data Report MI-81-1, 524 p., 9 fig.

Van1ier, K. E., 1966, Ground-water resources of the Battle Creek area, Michigan: Michigan Geological Survey Water Investigation 4, 52 p., 19 figs.

Weeks, E. P., 1969, Determining the ratio of horizontal to vertical permeabilit by aquifer-test analysis: American Geophysical Union Water Resources Research, vo1. 5, no. 1, pp. 196-214. 


\section{DEFINITION OF TERMS}

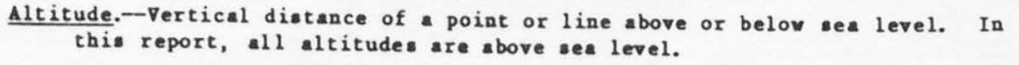

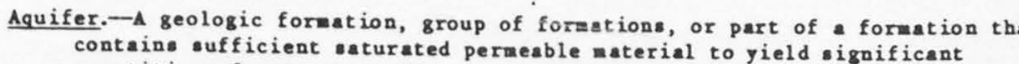

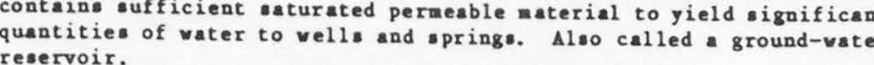

Base flov.--The discharge entering stream chanels as inf lov from ground water Bedrock.,-Designates consol idated rocke.

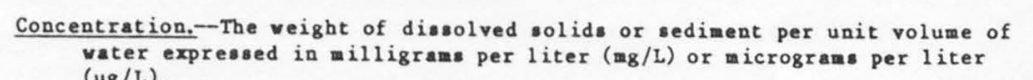
$(\mu / \mathrm{L})$.

Confining bed.--A body of relatively in
adjacent to one or more equifers.

Contour,--An imaginary line connecting points of equal altitude, vhether the
points are on the land surface, on a formation surface, or on a potentio-

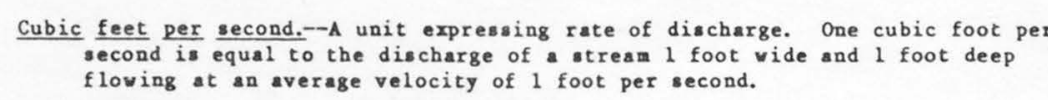

$\frac{\text { Dissolved solids.--Subatances present in vater that are in true chemical }}{\text { anlution. }}$

Divide--A line of separation between drainage gyatens. A topographic divide

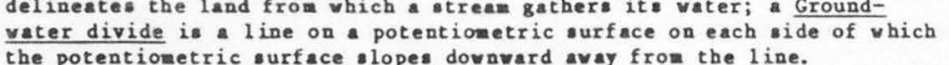

Effective porosity.-Amount of interconnected pore space in rocks available for
fluid tranasuis ion; the ratio of voluae of pore pasce to voluare of rock.

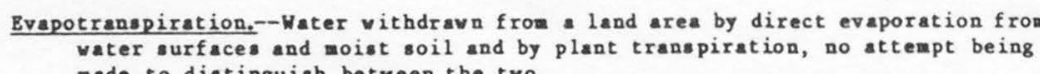

Practure,-A structural break or opening in bedrock.

Grain size--The classification range for the dianeter of particles, in

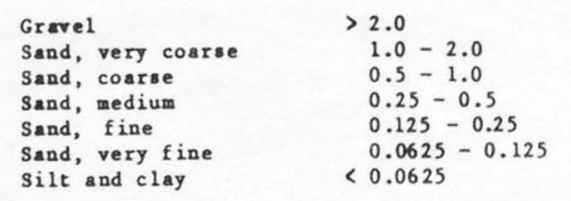

Ground water.- - Hater in the ground which is in the saturated
vel1s, iprings, and ground-vater runoff are supplied.

Cround-vater diacharge.--The diacharge of vater from the saturated zone by 1 ) piration and 2) artificial discharge through vella snd other piration and
structures.

Ground-vater runoff.--Ground water that has discharged into otream channels by page from saturated earth materials.

$\frac{\text { Hardness of vater.--Commonly refers to concentration of } \mathrm{CaCO}_{3} \text {. The classifica- }}{\text { tion range for hardness; in milligrams per } 1 \text { iter }\left(\mathrm{mg} / \mathrm{L} \text { ) of } \mathrm{CaCO}_{3} \text {, is as }\right.}$ tion range

$$
\begin{aligned}
& \text { Very Hard -- more than } 180 \\
& \text { Hard }-121 \text { to } 180 \\
& \text { Moderately hard } \\
& \text { soft }-0 \text { to } 60
\end{aligned}
$$

Head.--The height of the surface of a vater column above a standard datum that
Bydraulic conductivity.--The volume of water at the pravalling kadeetatic vough

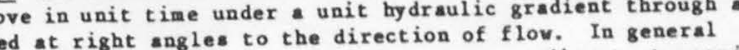

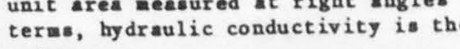

Bydreulic gradient,--The change in static head per unit distance in $\boldsymbol{A}$ given
direction. If not specified, the direction is generally underatood to be direction If not specified, the direction
that of the maximum $r a t e$ of decrease in head.

Bydrograph--A graph shoving the variation of atage, flov, velocity, discharge

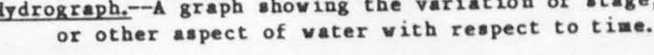

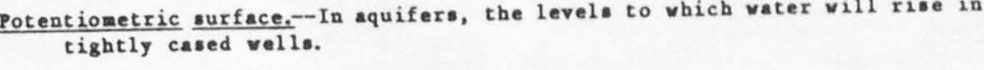

Recharge--The process by which vater is infiltrated and added to the zone of
saturation. Also, the quantity of vater added to the zone of gaturation. Runoff.-That part of precipication that appears in otreams; the vater draining
from $A$ a drea. When expreased in inches, it is the depth to vhich an areas

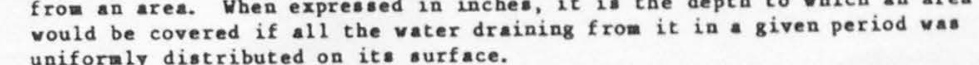
Specific capacity.--The rate of discharge of
dravdova of vater level vithin the vell.

Specific conductance.--A measure of the ability of vater to conduct an electric it can be used for approximating the dissolved-solide concentration of vater. For most natural vaters the ratio of diasolved-solide concentration (in
milligrana per liter) to specific conductance (in micromb) is in the range
0.5 to 0.8 .

Specific storage.--The volume of vater released from or taken
unit volume of the porous medium per unit change in head. Specific yield.--The ratio of the volume of vater which rock, after being
saturated, vill yield by gravity, to the volume of rock.

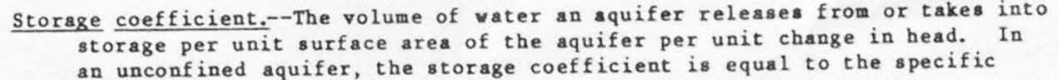

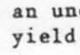

Subcrop-- - In this report, a bedrock formation or rock unit that directly under-
lies the glacial deposits and vould be exposed if all glacial deposita vere eis type curve.--Graphic method of solution of aquifer characteristics

Trangmissivity.--The rate at which water of the prevailing kinematic viscosity gradient. In general, the term refers to the ability of aquifer materia of transmit vater. It is equal to the product of hydraulic conductivity
and aquifer thickess, and is expressed in units of leagth squared per unit and aquifer
time $\left(L^{2} / t\right)$.

Hater table--That surface in an unconfined water body at wich the pressure is
atmos pheric.

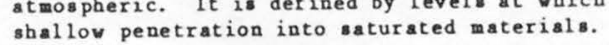


TABLES 
Table 3.--Description of rocks and soils from wells drilled by U.S. Geological Survey

\begin{tabular}{|c|c|}
\hline $\begin{array}{l}\text { Ye } 11 \\
\text { number }\end{array}$ & Lithology \\
\hline E1 & 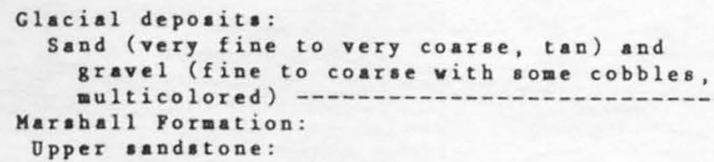 \\
\hline
\end{tabular}

Opper andatone:
Sanditone (very fine to fine, gray) - Pil1 -
Glacial deposits: Sand (aediua to very coarse, tan) and
clay (broun) Marshelil pormation

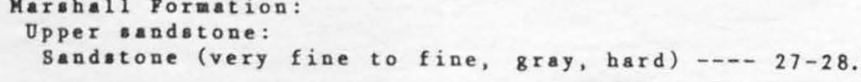

C1acial deposits:
clay (black) and peat (black) -

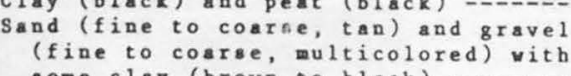
Watsher clay (bro

Sandatone (very

Glacial deposits:

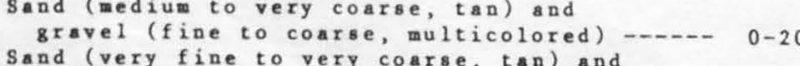

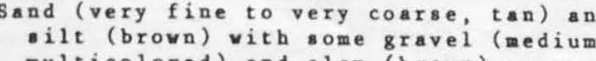

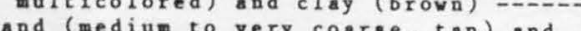
gravel (fine to coaroe, multicolored
gial Sand (very fine, gray) 8 ravel (fine,
multicolored), gitt (gray), and clo arsha11 Pormation

Upper andatone:
sandatone (very fine to fine, gray)

$72-78$

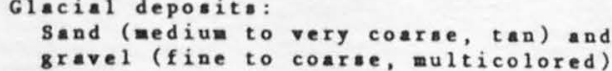
$-78-81$

Merobeli Poratio io

sand
sand at ane (very fine to fine, gray, very
herd
Mel1
number

Lithology

B6

Glacial depolita:
c1ay (red to brown), silt (brown), sand
(medium to very cosire, tan) and gome

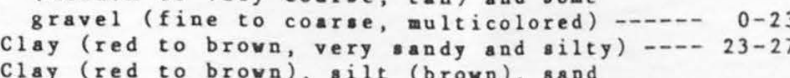

medium to very coarse, tan), and oome
gravel (fine to coarse, multicolored) - - 27-4 Matshave pormation:
Upperiandatone:

(vine

lacise deposits

(to very coarse, tan) - -

Dar
Upper sandatone:

fine to fine, gray) - - -

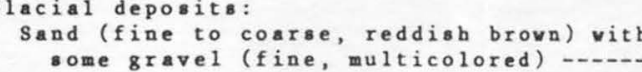

$0-31$

Glacial deposits:
Sand (medium to

gravel (fine to medium arse, tan) and and $c 1$ ay (broun) -Opper sandatone:

Glacial deposits:
Sand (fine to medium, tan) Warahall pormation

Opper sandstone:
Sandstone (very fine to fine, gray) -

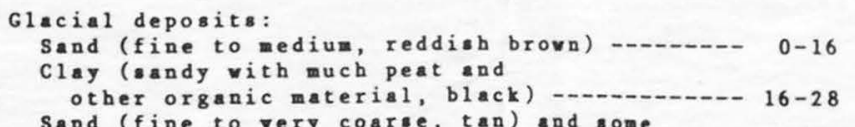

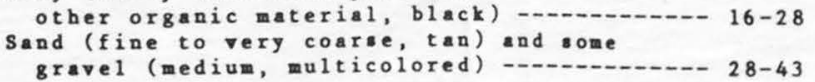

\begin{tabular}{lll}
$\begin{array}{l}\text { Yel1 } \\
\text { number }\end{array}$ & Lithology & $\begin{array}{c}\text { Deppth } \\
\text { feet }\end{array}$ \\
\hline
\end{tabular}

Glaciel deposits:
sand (aedium to coarse, tan) with some
clay (brovn)- $0-10$

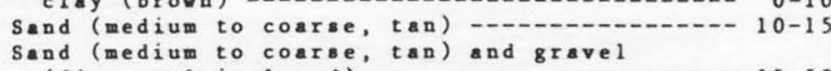
(fine, multicolored) and ( $f$ ine to medium, tan), gravel (fine, multicolored), and clay
(tan to brown) - $58-60$ Sand (aediuk to very cosse, tan)
and gravel (fine, multicolored) Sand (redium to very coarse, tan)

gravel (fine, multicolored) vith

B13 Glacial deposits:
Sand (medium, brown) vith some grave $0-44$ sand (medium, gray to brown), gilt
(gray, to brovn), and clay (grayto to

upper andatone:
Sandstone (very fine to fine, gray) - - -

E14

Glacial deposits:
Sand (medium tan) and gravel (fine, multicolored

Upper sandstone:
Sandetone (very

Gacial deposits:
Sand (fine to medium, tan) Sand (fine, tan), silt (tan), and clay Sand (fine to gediu, tan) -
Wube11 pormation:

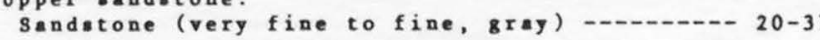


Table 3.--Description of rocks and soils from wells drilled by U.S. Geological Survey--Continued

\begin{tabular}{lcc}
\hline $\begin{array}{l}\text { Mel1 } \\
\text { number }\end{array}$ & Lithology & $\begin{array}{c}\text { Depth } \\
\text { feet }\end{array}$ \\
\hline
\end{tabular}

E16 Marshal1 Pormation
(cont.) Mperandetone: Glacial deposits
Sand (fine

grave1 (fine, multicolored) Mrohall pormation

Sandotone (very fine to fine, gray) --- 10-32

818

Glacial deposits:

(yeliov to tan)

broun). and ome gravel (fine to

Marshall pormatio:

Upper sandatone:
Sandatone (very

Gacial deposits:
sand (f

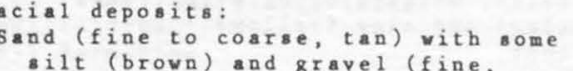

Marshall pormation

$0-11$

Opper andstone:
Sandstone (very

Glacisi deposits:
sand (very fine

(IIfery fine to coarse, tan) vith

(fine, multicol
Marshall pormation:

Opper sandstone:

Glacise deposits:

(fine to very coarse, $t a n$ ) and

8ravel (fine mosty black and
vhite) vith traces of silt (brovn)

Opper sandatone:

$-15-25$

8225

Glacial deposits:

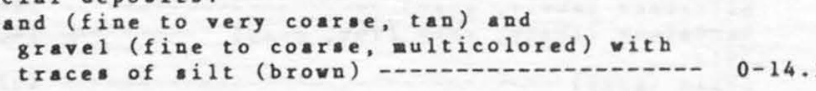

\begin{tabular}{lll}
\hline $\begin{array}{l}\text { hel1 } \\
\text { number }\end{array}$ & Lithology & $\begin{array}{l}\text { Depth } \\
\text { feet }\end{array}$ \\
\hline
\end{tabular}

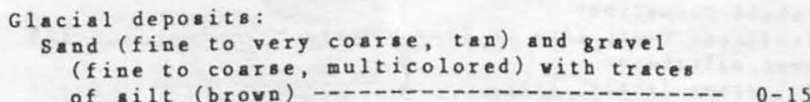
ond (very fine to very coarse, tan) and
gravel (fine to very coarse, multicolored;

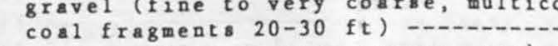

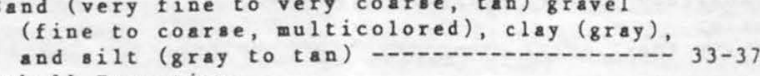
arshali Pormation
Opper sandetone:

Sandatone (very fine to medium, gray) -..--.-- 37-40 Sandstone (silty very fine to fine, gray
vith gome brown) - 40-59 Upper siltstone:
Siitstone (sady, gray) Lover sandst one:

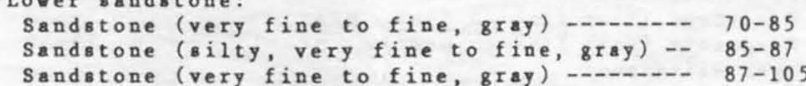
Siltatone (shaly, gray) $-10-105-108$
Sandstone (shaly, very fine to fine, gray) $-108-11$

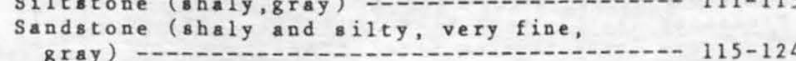

B23

clacial deposits:

medium to $0-10$ and (fine to very coerse, gray to tan) and
gravel (fine to coerse, ulticolored) Sond (fine to very coaree, tan), gravel sand (fine to very coarae, tan), gravel
(fine, multicolored), and soue ilt

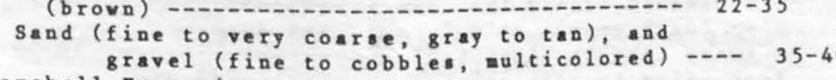

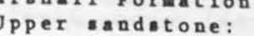

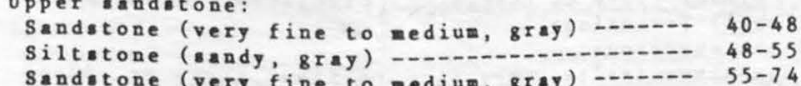
pper aita (very fine to nedium, gray) - gray)
Shate:
shase
Ye11
number

Lithology

Depth
feet

E23 Marsbal1 Pormation
(cont.) Lover andetone:

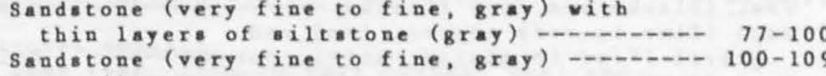
$-109-111$ Siltatone (obaly and andy, gray) -
sandatone (oilty and atyly, very fine $111-114$
$114-119$
$119-125$ siltatone (obaly, gray) -ie- gray) Shale (gray)
sandatone (ohaly and ailty, very fine,

E24 clacial deposits

Glacial deposits:
sand (very fine to very coarse, tan), gravel
(fine to coarse, multicolored), ooje iilt (fine to coarse, multicolored), ame -ilt
(brown) and oome clay (dark broun) Sand (very fine to very coarse, $\tan$ ) sand (fine to very coarse, tan), and gravel
(fine to medium, multicolored) vith oome

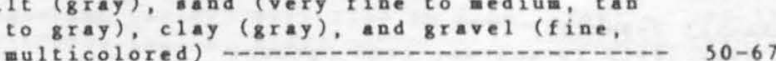
Marshall Pormation

Opper andatole:
sandotone (very fine to medium, green
to gray) to gray) (very fine to

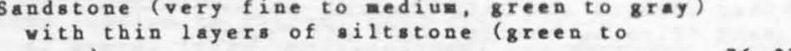

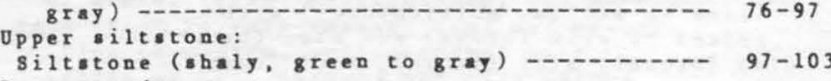

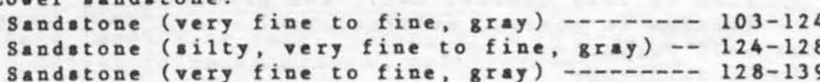

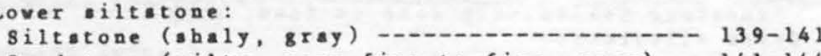

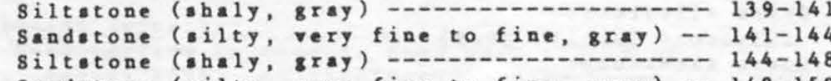
shale:
Shale (dark gray) - - 


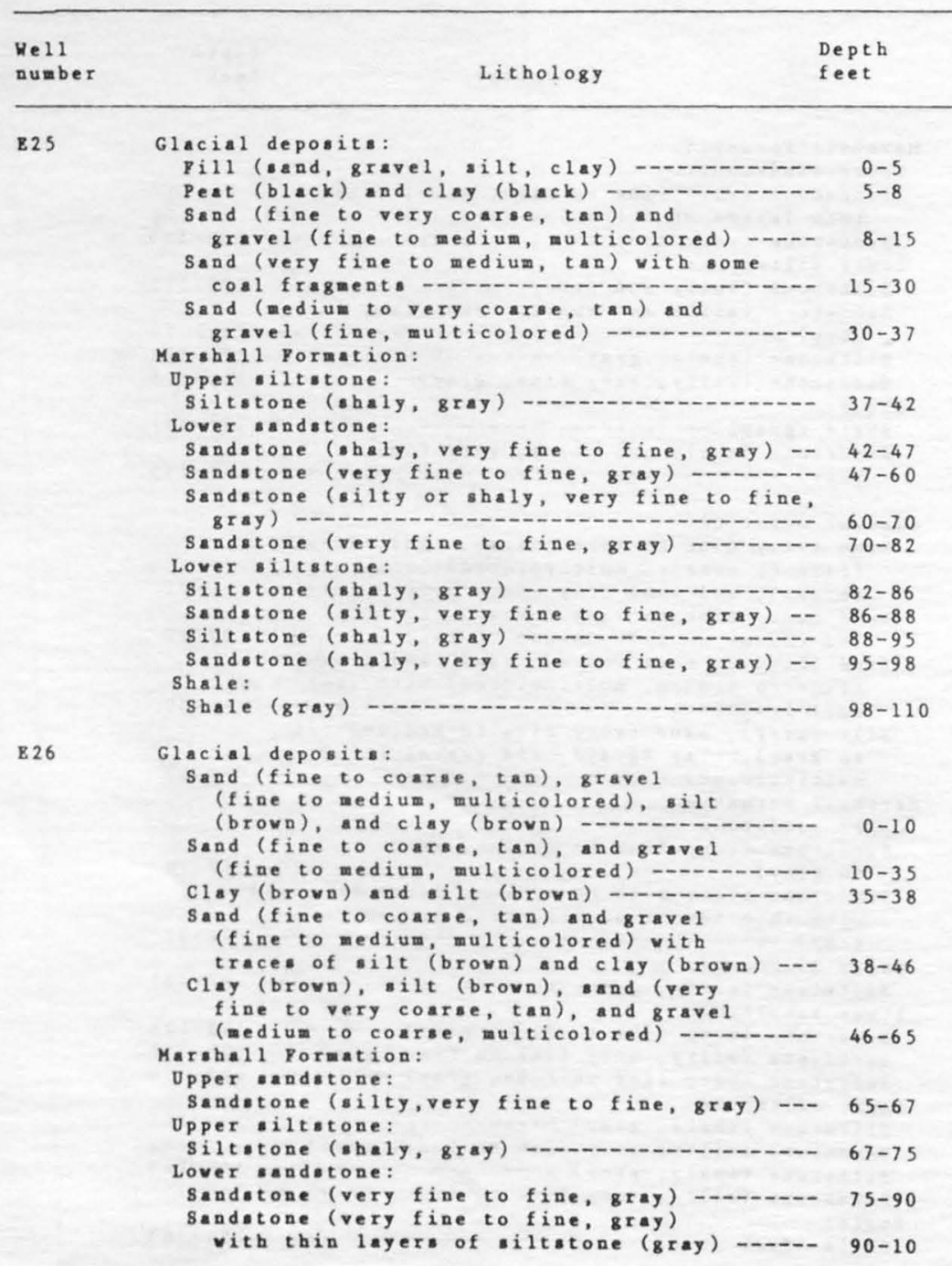

\begin{tabular}{|c|c|c|}
\hline $\begin{array}{l}\begin{array}{l}\text { Ye } 11 \\
\text { nuaber ber }\end{array} \\
\text { not }\end{array}$ & Lithology & $\begin{array}{l}\text { Depth } \\
\text { feet }\end{array}$ \\
\hline $\begin{array}{l}826 \\
\text { (cont.) }\end{array}$ & 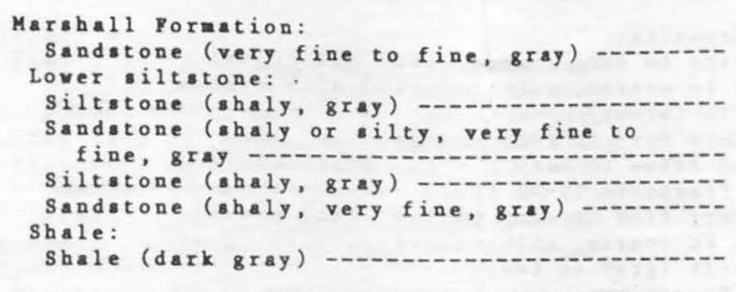 & $\begin{array}{r}100-108 \\
-108-111 \\
-111-115 \\
-115-119 \\
119-125 \\
-125-135\end{array}$ \\
\hline E 27 & 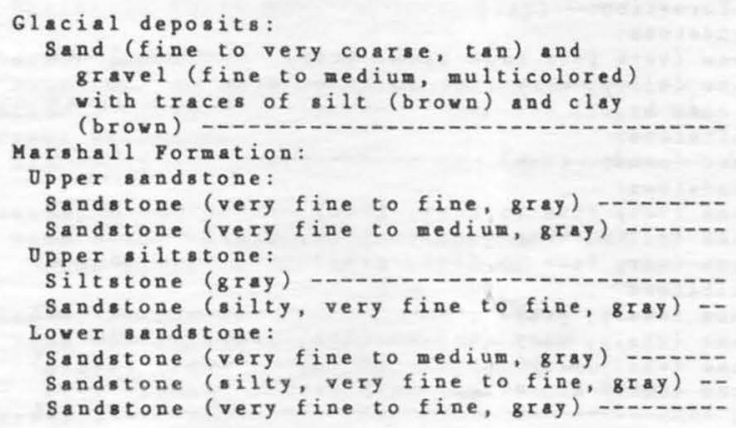 & 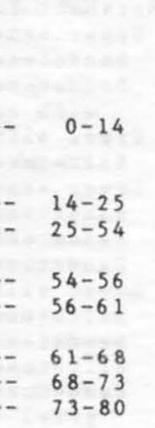 \\
\hline E28s & 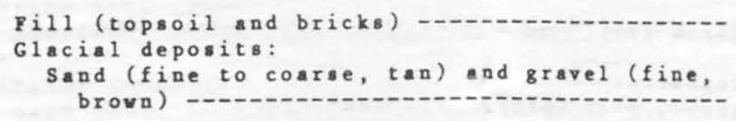 & $-\quad 0-8$ \\
\hline E28D & 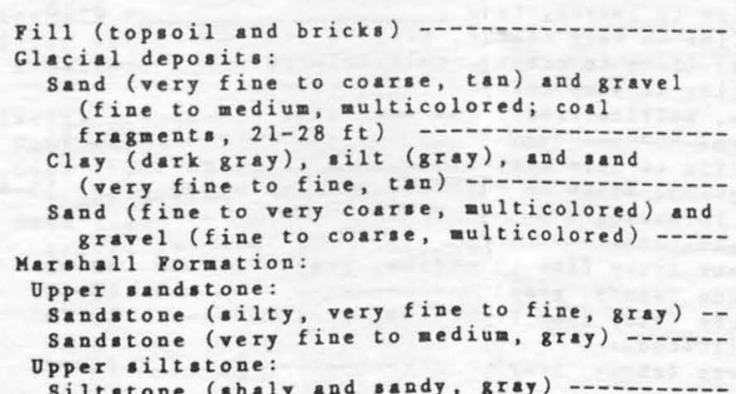 & $\begin{array}{r}8-28 \\
-\quad 32-32 \\
-\quad 42-46 \\
-\quad 46-53\end{array}$ \\
\hline
\end{tabular}

\begin{tabular}{lll}
\hline $\begin{array}{l}\text { Well } \\
\text { number }\end{array}$ & Lithology & $\begin{array}{l}\text { Depth } \\
\text { feet }\end{array}$ \\
\hline
\end{tabular}

B28D Marshal1 pormation
(cont.) Lover andatone:

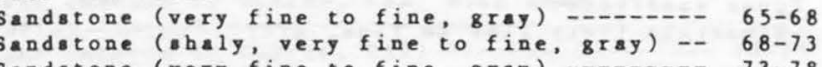

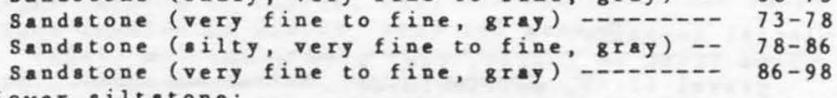

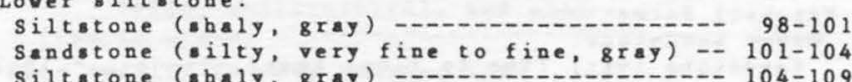

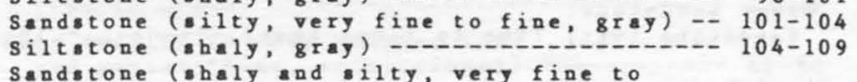
Sandstone (obaly and silty, very fine to
fine, gray) - 109-116 Shale:
shale (gray) Shale (sandy and sity, gray) -
Shate (dark gray) - $122-130$

829

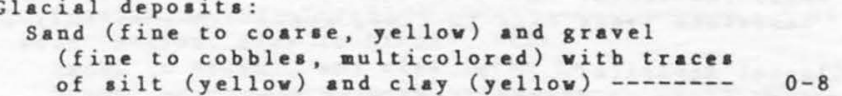
Marshall pormatio
Upper sandatone:

Sandatone (very fine to medium, yellow) -...- 8-2

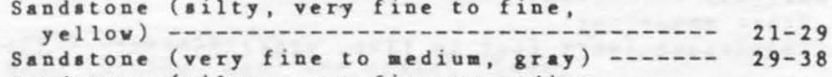
Sandstone (oilty, very fine to medium.

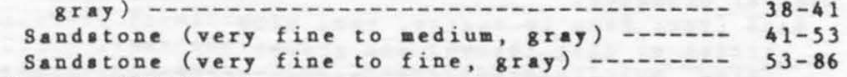
Uper ailtatone:
Siltstone (ohaly, gray) - Lover sandstone:

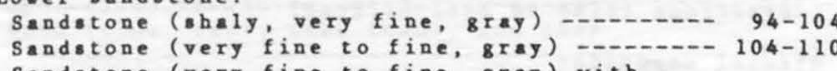
sandetone (very fine to fine, gray) with
thin layers of aitatoe (gray) - 110-118

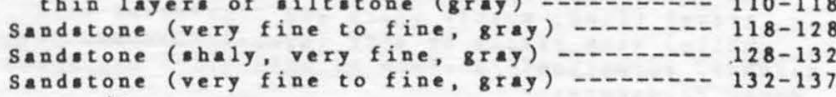
over siltatone:

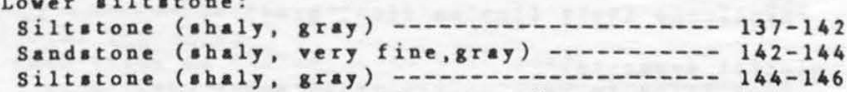

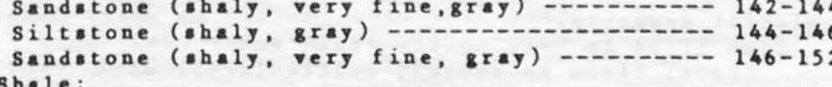
shale:
shale (gray) - $-152-156$ 
Table 3.--Description of rocks and soils from wells drilled by U.S. Geological Survey--Continued

$\substack{\text { Yel1 } \\ \text { number }}$
und

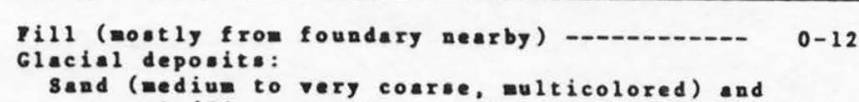

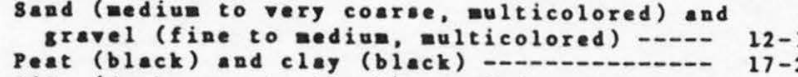

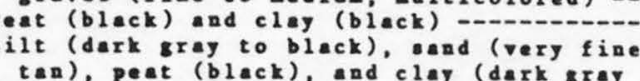
tan biack)
to biack Band (Very fine to very coarsed mostly tan)
and gravel (fine, gulticolored) sand (very fine to fine, tan), illt (tan), silt (gray to ton), and (very fine to nediue, 44-6

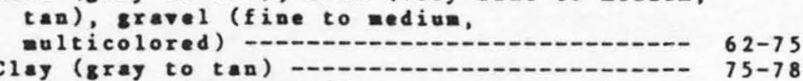
Clay (gray to tan)
sand (rery fie to gedium, muticicolored) vith

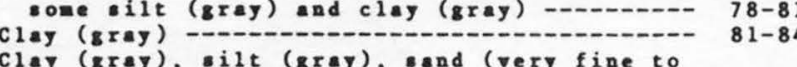
gravel (fine, $84-91$

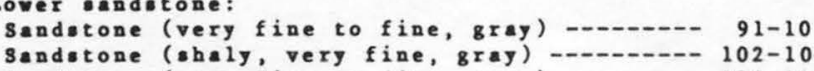
sandetone (very fine to fine, gray) -------- $106-11$

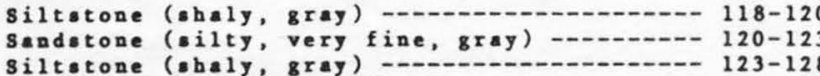
sandotone (obaly, gery fine, gray) -------- $128-133$
Shate:

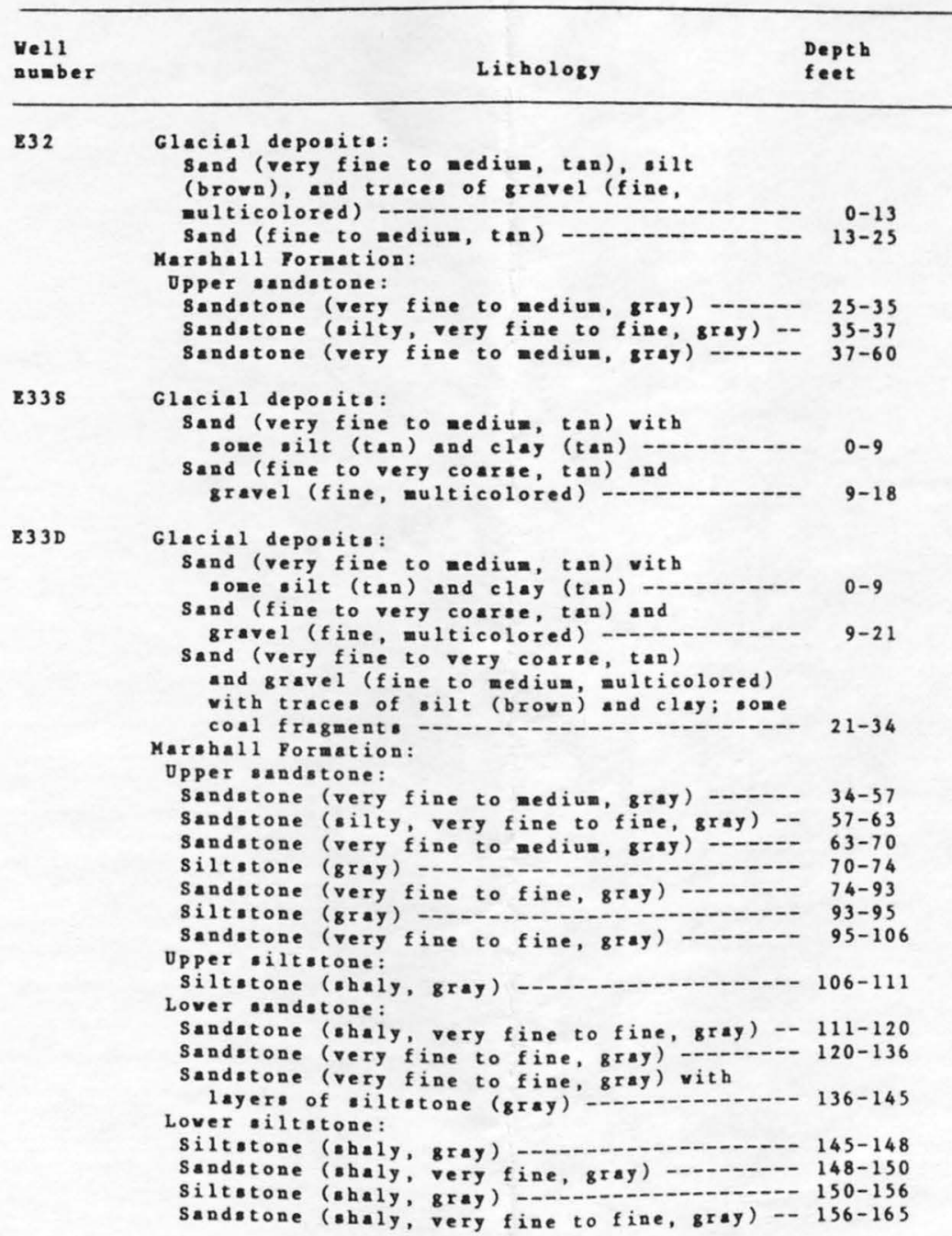

\begin{tabular}{lll}
\hline $\begin{array}{l}\text { Yel1 } \\
\text { uubber }\end{array}$ & Lithology & $\begin{array}{l}\text { Depth } \\
\text { feot }\end{array}$ \\
\hline
\end{tabular}

S330
(cont.) Shale: (dak gray) -
shale (derk

834 Glacial deposits:

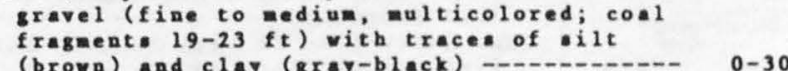
Marshal1 Yormation:
Opper andet one:

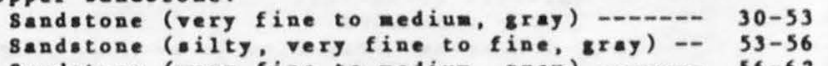

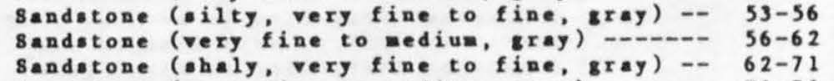
(very $i$ ine to nodise

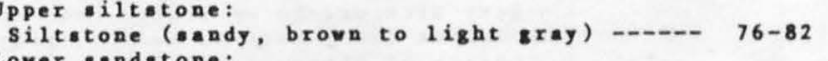

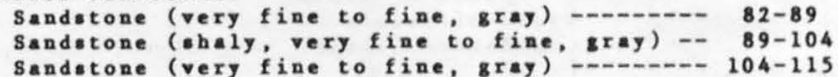

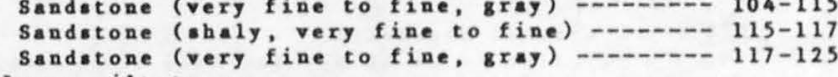

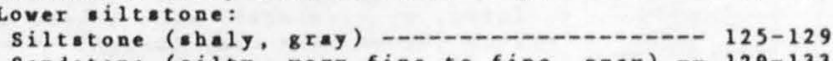

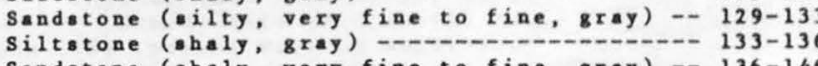
Shale: (dark gray) -
shale (dark Clacial deposits

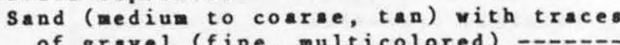
Sand (fine to very coarse, tan) and gravel traces of oilt (brovn) and clay (broun to black)
and (aedium to very coarse, gray to brovn) and

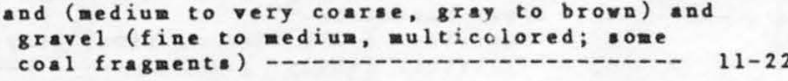

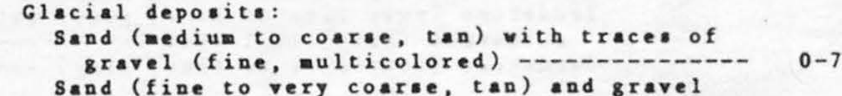

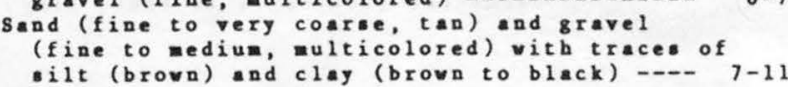


Table 3.--Description of rocks and soils from wells drilled by U.S. Geological Survey--Continued

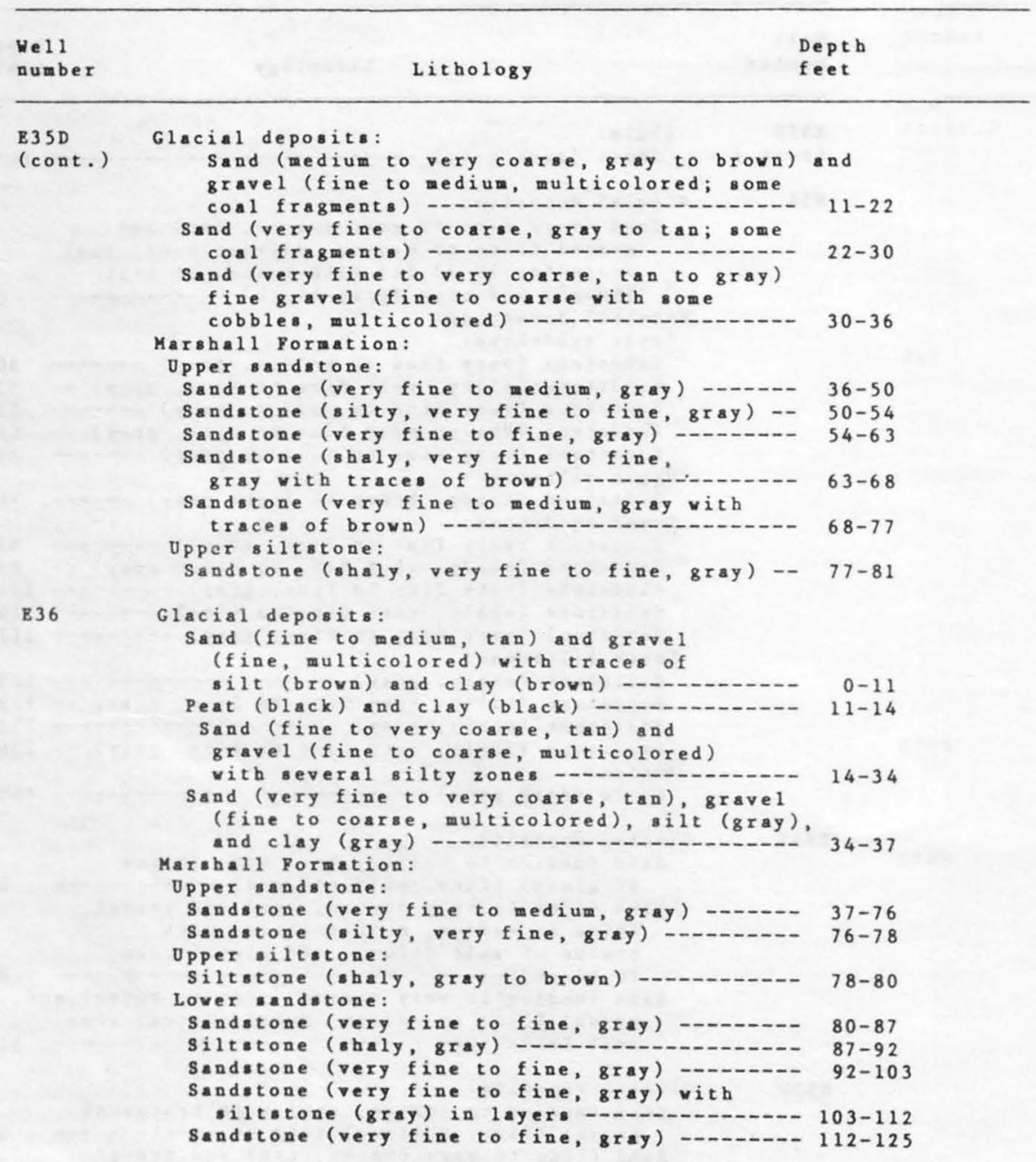


USGS LIBRARY - RESTON 